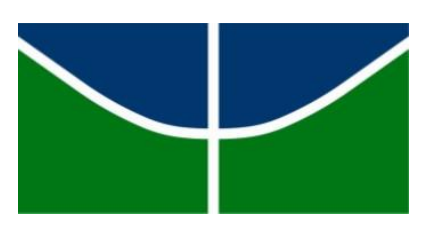

\author{
UNIVERSIDADE DE BRASÍLIA \\ FACULDADE DE ECONOMIA, ADMINISTRAÇÃO E CONTABILIDADE \\ DEPARTAMENTO DE ECONOMIA \\ MESTRADO EM ECONOMIA DO SETOR PÚBLICO
}

TAÍS NOVO DUARTE

\title{
BALANCEAMENTO ATUARIAL PER CAPITA E PERFIL DE INVESTIMENTO DOS PLANOS DE BENEFÍCIOS DAS ENTIDADES FECHADAS DE PREVIDÊNCIA COMPLEMENTAR: UMA APLICAÇÃO DA TEORIA DO CICLO DE VIDA COM DADOS DE PAINEL
}




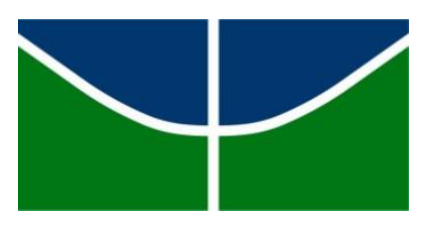

UNIVERSIDADE DE BRASÍLIA

FACULDADE DE ECONOMIA, ADMINISTRAÇÃO E CONTABILIDADE DEPARTAMENTO DE ECONOMIA MESTRADO EM ECONOMIA DO SETOR PÚBLICO

TAÍS NOVO DUARTE

\section{BALANCEAMENTO ATUARIAL PER CAPITA E PERFIL DE INVESTIMENTO DOS PLANOS DE BENEFÍCIOS DAS ENTIDADES FECHADAS DE PREVIDÊNCIA COMPLEMENTAR: UMA APLICAÇÃO DA TEORIA DO CICLO DE VIDA COM DADOS DE PAINEL}

Dissertação de Mestrado apresentada ao Departamento Economia da Universidade de Brasília, como parte dos requisitos necessários à obtenção do título de Mestre em Economia do Setor Público.

Orientador: Prof. Dr. Paulo Springer de Freitas

BRASÍLIA

2015 
Ficha catalográfica elaborada pela Biblioteca Central da Universidade de Brasília. Acervo 1016842.

Taís Novo Duarte.

C355 i Balanceamento atuarial per capita e perfil de investimento dos planos de benefícios das entidades fechadas de previdência complementar: uma aplicação da teoria do ciclo de vida com dados de painel/ Taís Novo Duarte. - - 2015.

xvii, $77 \mathrm{f} .:$ il. ; $30 \mathrm{~cm}$.

Dissertação (mestrado) - Universidade de Brasília, Faculdade de Economia, Administração e Contabilidade, Departamento de Economia, Mestrado em Economia do Setor Público, 2015.

Inclui bibliografia .

Orientação: Paulo Springer de Freitas.

1. 2. I. Springer, Paulo. II. Título.

CDU 336.215 .2 


\section{AGRADECIMENTOS}

Agradeço primeiramente às pessoas mais próximas e importantes para mim por terem tido paciência durante esse processo: minha mãe Luiza e meu pai Artur por sempre terem priorizado a educação na criação do Tiago e minha em detrimento de outras coisas. À Lara, por ser tão compreensiva e querida durante esse ciclo.

Ao meu orientador, Professor Springer: muito obrigada pelos comentários, disposição, interesse e, principalmente, por respeitar meu tempo. Admiro-te como pessoa, professor, economista e, principalmente, pelo papel que tiveste na feitura dessa dissertação.

Também não posso deixar de mencionar meus colegas da Previc, mais especificamente aos da Diretoria de Assuntos Atuariais, Contábeis e Econômicos e, de forma especial aos da Coordenação-Geral de Monitoramento Atuarial (CGMA), companheiros de discussões diárias sobre o comportamento e as características dos planos de benefícios que são o insumo do nosso trabalho. 
RESUMO

\title{
BALANCEAMENTO ATUARIAL PER CAPITA E PERFIL DE INVESTIMENTO DOS PLANOS DE BENEFÍCIOS DAS ENTIDADES FECHADAS DE PREVIDÊNCIA COMPLEMENTAR: UMA APLICAÇÃO DA TEORIA DO CICLO DE VIDA COM DADOS DE PAINEL.
}

\author{
Autora: TAÍS NOVO DUARTE. \\ Orientador: Prof. Dr. Paulo Springer de Freitas \\ Programa de Mestrado em Economia do Setor Público Brasília, \\ Maio de 2015.
}

O presente trabalho teve como objetivo analisar o balanceamento atuarial per capita e o perfil de investimento de 605 planos de benefícios administrados pelas entidades fechadas de previdência complementar (EFPC) brasileiras nos anos de 2008 a 2014. Com base na teoria de vida do capital humano, o trabalho se propôs a analisar, por meio de dados de painel, se os planos de benefícios mais maduros, independentemente da modalidade, possuem perfil de investimento menos arriscado, conforme prevê a teoria econômica.

Palavras-chaves: planos de benefícios, teoria do ciclo de vida do capital humano, balanceamento atuarial per capita, perfil de risco. 


\begin{abstract}
This work aimed to analyze the actuarial per capita balancing of 605 benefit plans managed by the Brazilian pension funds from 2008 to 2014. Based on the life-cycle human capital theory and using panel data modelling, this dissertation analyzed if the more mature pension plans have less risky investment profiles, as predicted by the economic theory.
\end{abstract}

Key-words: benefit plans, life-cycle human capital theory, actuarial per capita balancing, risk profile. 


\section{SUMÁRIO}

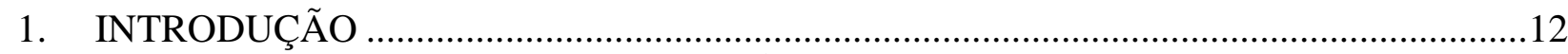

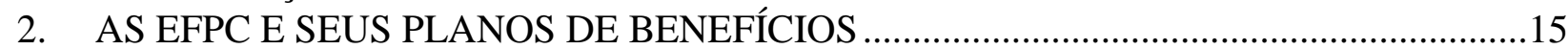

2.1 Contextualização das entidades fechadas de previdência complementar no sistema

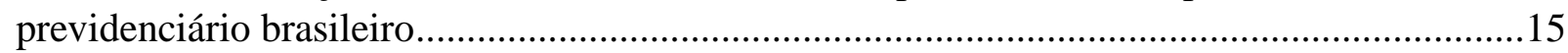

2.2 Os planos de benefícios das EFPC: tipos de benefícios, modalidades e características

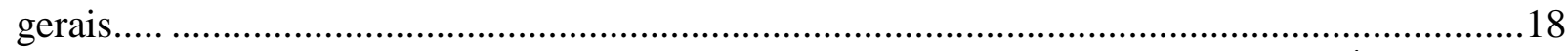

3. A TEORIA DO CICLO DE VIDA NO CONTEXTO DOS PLANOS DE BENEFÍCIOS.......20

3.1 Revisão bibliográfica das teorias do ciclo de vida e das finanças do ciclo de vida ..............20

3.2 Revisão dos estudos empíricos da teoria do ciclo de vida aplicada aos investimentos dos

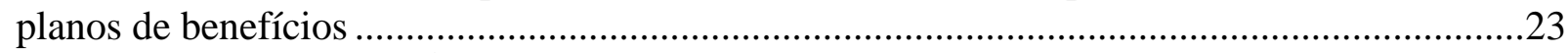

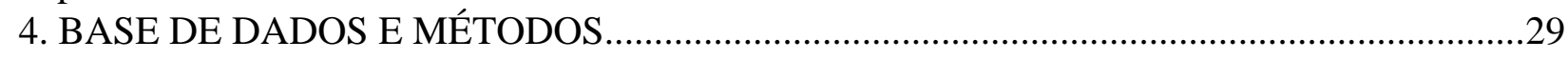

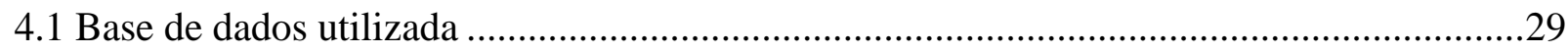

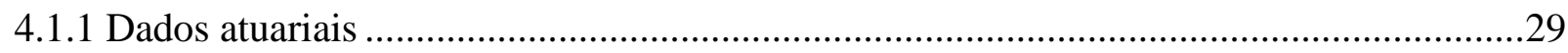

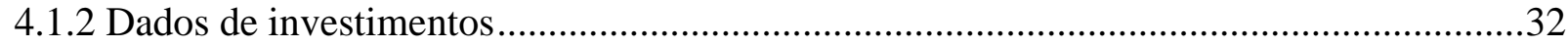

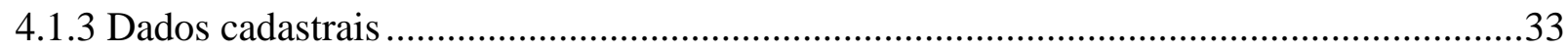

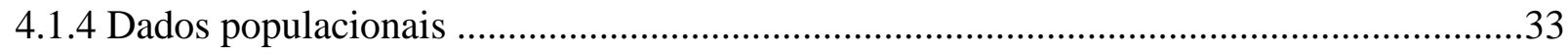

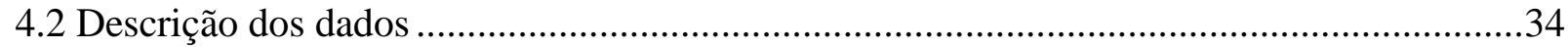

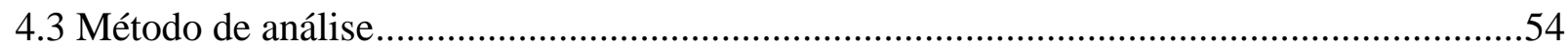

4.3.1 O balanceamento atuarial per capita e seus efeitos não observados..................................58

4.3.2 O perfil de risco dos planos e seus efeitos não observados ...............................................64

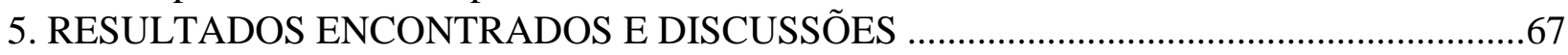

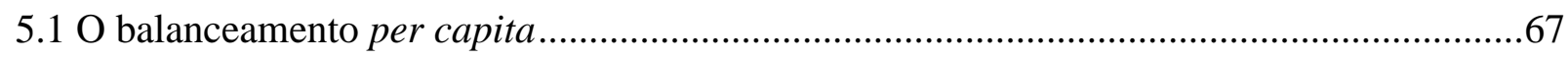

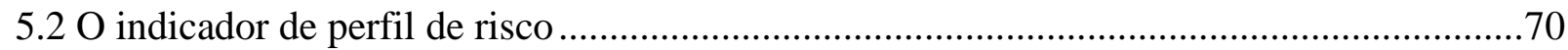

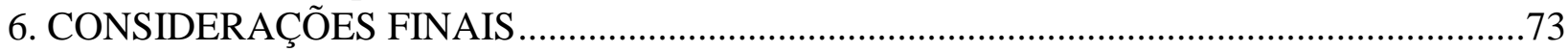

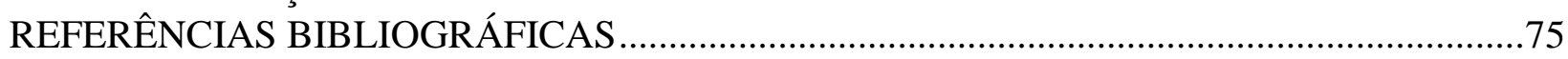

\section{LISTA DE TABELAS}

Tabela 1 - Distribuição dos planos por tipo e modalidade

Tabela 2 - Teste do multiplicador de Lagrange Breusch-Pagan para efeitos aleatórios 
Tabela 3 - Teste F para efeitos fixos

Tabela 4 - Teste F de Chow de quebra estrutural/empilhamento de dados

Tabela 5 - Teste do multiplicador de Lagrange Breusch-Pagan para efeitos aleatórios

Tabela 6 - Teste F para efeitos fixos

Tabela 7 - Teste de Hausman

Tabela 8 - Regressão linear múltipla com dados empilhados

Tabela 9 - Regressão com efeitos fixos (Within)

\section{LISTA DE FIGURAS}

Figura 1 - Organização do sistema previdenciário brasileiro

\section{LISTA DE GRÁFICOS}

Gráfico 1 - Evolução do número de Demonstrações Atuariais

Gráfico 2 - Evolução do balanceamento atuarial agregado dos planos de benefícios da amostra (em R \$ bilhões)

Gráfico 3 - Evolução do balanceamento atuarial agregado da população dos planos de benefícios (em R \$ bilhões)

Gráfico 4 - Evolução do balanceamento atuarial per capita dos 605 planos de benefícios da amostra (R\$ em milhões)

Gráfico 5 - Evolução do balanceamento atuarial per capita da população de planos (em R\$ milhões)

Gráfico 6 - Evolução da situação atuarial dos planos da amostra

Gráfico 7 - Evolução da situação atuarial da população de planos

Gráfico 8 - Distribuição dos planos de benefícios por modalidade

Gráfico 9 - Evolução das modalidades da população de planos de benefícios

Gráfico 10 - Evolução do patrocínio predominante na população de planos de benefícios

Gráfico 11 - Distribuição dos planos de benefícios da amostra por patrocínio predominante

Gráfico 12 - Provisões matemáticas e patrimônio de cobertura por patrocínio predominante população de planos (em R \$ bilhões)

Gráfico 13 - Provisões matemáticas e patrimônio de cobertura por patrocínio predominante amostra de planos (em R $\$$ bilhões) 
Gráfico 14 - Balanceamento atuarial per capita por patrocínio predominante da amostra(em R\$ milhões)

Gráfico 15 - Evolução do número total de participantes: população versus amostra

Gráfico 16 - Maturidade dos planos de benefício definido: população versus amostra

Gráfico 17 - Maturidade dos planos de contribuição variável: população versus amostra

Gráfico 18 - Maturidade dos planos de contribuição definida: população versus amostra

Gráfico 19 - Evolução do perfil de risco médio: amostra versus da população de planos

Gráfico 20 - Evolução da taxa real anual de juros média dos planos BD e CV

Gráfico 21 - Evolução da taxa real anual de juros média dos planos CD 


\section{LISTA DE NOMENCLATURAS E ABREVIAÇÕES}

BD - Benefício Definido

CD - Contribuição Definida

CGPC - Conselho de Gestão de Previdência Complementar

CMN - Conselho Monetário Nacional

CNPC - Conselho Nacional de Previdência Complementar

CV - Contribuição Variável

EAPC - Entidade Aberta de Previdência Complementar

EFPC - Entidade Fechada de Previdência Complementar

EUA - Estados Unidos da América

PIB - Produto Interno Bruto

PNB - Produto Nacional Bruto

PREVIC - Superintendência Nacional de Previdência Complementar

RPCA - Regime de Previdência Complementar Aberta

RPCF - Regime de Previdência Complementar Fechada

SELIC - Sistema Especial de Liquidação e de Custódia

SUSEP - Superintendência de Seguros Privados 


\section{INTRODUÇÃO}

O estudo aqui explicitado tem como objeto de análise algumas características dos planos de benefícios administrados pelas entidades fechadas de previdência complementar (EFPC).

O regime de previdência complementar é parte integrante do desenho do atual sistema previdenciário brasileiro e constitui um de seus pilares, em conjunto com o regime de previdência social, conforme demonstra a Figura 1 abaixo:

Figura 1 - Organização do sistema previdenciário brasileiro

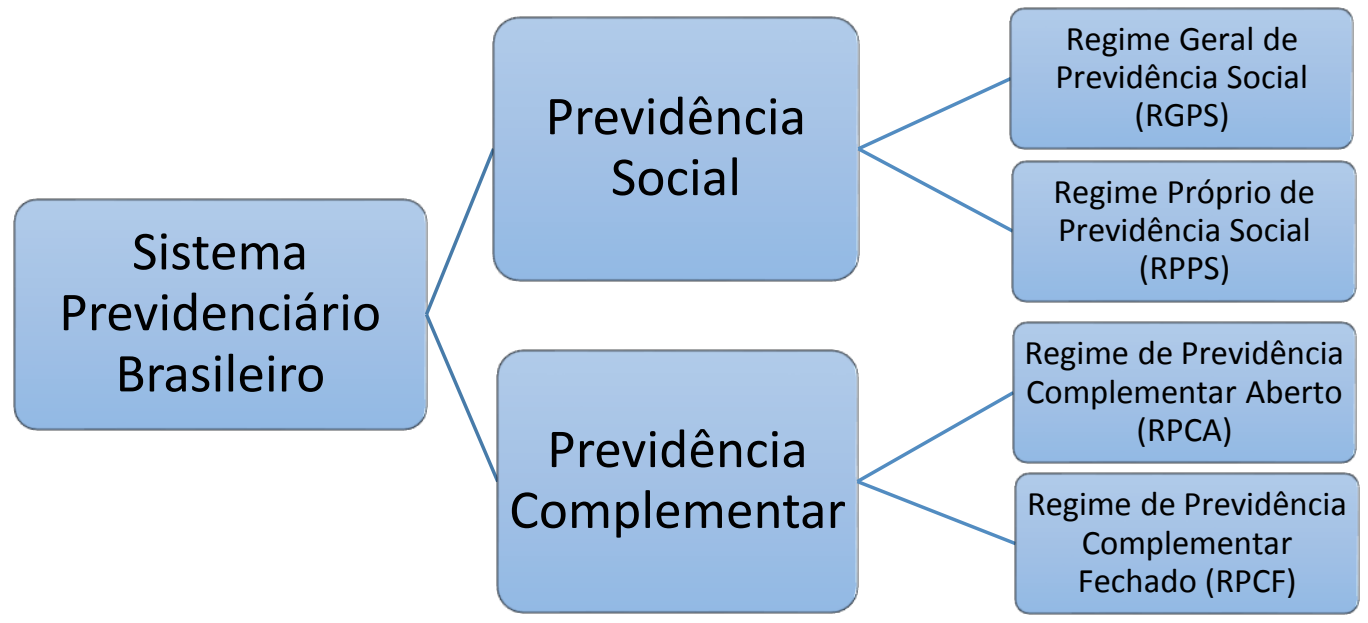

A previdência social, primeiro pilar do sistema brasileiro, é administrada pelo setor público, de filiação compulsória para todos os trabalhadores pertencentes ao mercado formal de trabalho e pode ser dividida em dois subgrupos: regime geral de previdência social (RGPS) e o regime próprio de previdência social (RPPS). O RGPS engloba todos os trabalhadores regidos pela Consolidação das Leis do Trabalho (CLT), além dos servidores públicos ocupantes de cargo em comissão sem vínculo efetivo, dos trabalhadores avulsos, dos trabalhadores rurais, dos segurados especiais e dos facultativos e é administrado pelo Instituto Nacional de Seguridade Social (INSS) ${ }^{1}$. Já o RPPS oferece cobertura previdenciária aos servidores públicos titulares de cargos efetivos e possui administração descentralizada, dependendo do ente da Federação (União, Estados e Municípios) ao qual o regime esteja vinculado.

A previdência complementar, que constitui o segundo pilar da previdência no Brasil, é de filiação voluntária, administração privada e também se divide em dois subgrupos: o regime de

\footnotetext{
${ }^{1}$ Ver artigos 11 a 13 da Lei no 8.213, de 24 de julho 1991 para maiores detalhes dos segurados obrigatórios da Previdência Social.
} 
previdência complementar aberto (RPCA) e o regime de previdência complementar fechado (RPCF). Esta dissertação analisará o RPCF, constituído pelas EFPC e seus planos de benefícios, cujos participantes têm de estar, de alguma forma, vinculados ao patrocinador ou ao instituidor do plano, seja na condição de empregados ou de associados.

Os planos de benefícios podem ser constituídos em três modalidades, quais sejam: benefício definido (BD), contribuição variável (CV) e contribuição definida (CD). Em um plano BD o valor do benefício é conhecido e normalmente é vinculado ao salário recebido durante a vida laborativa, ou ao tempo de trabalho do indivíduo. Em um plano CD cada participante contribui com um percentual de seu salário para uma conta individual e essas contribuições são utilizadas para comprar ativos financeiros que serão acumulados, assim como seus rendimentos (Rangel, 2013) e o valor do benefício normalmente só será conhecido no momento da aposentadoria ${ }^{2}$. Já os planos CV são aqueles que mesclam características de planos BD e CD e transitam entre uma definição e outra.

Segundo dados divulgados pela Superintendência Nacional de Previdência Complementar (PREVIC) $^{3}$, existem hoje no Brasil 317 EFPC, as quais administravam no final de 2014 R 704 bilhões em ativos totais, uma representatividade em torno de $12,75 \%$ do produto interno bruto (PIB) registrado no mesmo período ${ }^{4}$. Além da magnitude de recursos administrados pelas EFPC, o que por si só já seria um motivo relevante para analisar o funcionamento e a dinâmica dessas entidades, principalmente na administração dos seus planos de benefícios, é importante apontar que em dezembro de 2014 o RPCF contava com cerca de 3.254 .075 participantes, sendo que $22 \%$ desses já recebiam algum tipo de benefício.

Registro importante constante dos dados disponíveis e que caracteriza o mercado das EFPC no Brasil, é o fato de que grande parte dos recursos administrados se encontram concentrados em 3 EFPC, em ordem: Previ ${ }^{5}$, Petros ${ }^{6}$ e Funcef $^{7}$. Juntas essas 3 EFPC, todas com patrocínio público federal, concentravam em dezembro de 2014 algo em torno de 43,3\% de todos os ativos do mercado

\footnotetext{
2 O uso de simulações financeiras permite a previsão da renda de aposentadoria com razoável grau de acerto.

3 Documento denominado “Estatística trimestral - Dezembro de 2014", constante do link: http://www.previdencia.gov.br/wp-content/uploads/2015/04/RelatorioPrevic4trim2014FINAL.pdf .

${ }^{4}$ Segundo dados divulgados pelo Instituto Brasileiro de Geografia e Estatística (IBGE) o PIB foi de R\$ 5,52 trilhões em 2014.

${ }^{5}$ Caixa de Previdência dos Funcionários do Banco do Brasil.

${ }^{6}$ Fundação Petrobrás de Seguridade Social.

${ }^{7}$ Fundação dos Economiários Federais.
} 
dos fundos de pensão brasileiros. Essa concentração observada se agrava quando se leva em consideração o fato de que as EFPC com patrocínio público federal possuem grande influência política em suas administrações, pois as regras de representatividade nas instâncias de governança dos fundos de pensão permitem que suas patrocinadoras nomeiem diretores e conselheiros que são responsáveis pelas decisões de investimento e gestão dessas entidades.

Dada a relevância das EFPC como investidores institucionais, como provedores de benefícios previdenciários a uma parcela da população brasileira e sabendo da força e influência políticas que são exercidas sobre grande parte delas, o presente estudo buscou contribuir com um levantamento e cruzamento de dados atuariais, cadastrais, de investimentos e populacionais até então inéditos na literatura nacional, a fim de trazer luz ao tema. Além do levantamento e cruzamento dos dados dos planos de benefícios administrados pelas EFPC brasileiras, o estudo buscou confrontar alguns preceitos da teoria do ciclo de vida do capital humano, com a finalidade de verificar se o comportamento desses planos está de acordo com tal teoria econômica.

Para tanto, o estudo buscou responder à seguinte pergunta de pesquisa:

- Os planos de benefícios mais maduros possuem um perfil de investimento menos arriscado do que os planos com menor maturidade?

Segundo os resultados da teoria do ciclo de vida do capital humano, a fração de riqueza financeira do(s) indivíduo(s) investida em ativos de maior risco deve diminuir ao longo dos anos de vida, basicamente por duas razões: a primeira delas deriva do fato de o capital humano (trabalho) diminuir como proporção da riqueza total do indivíduo conforme os anos passam e a segunda da capacidade que os indivíduos possuem de flexibilizar sua oferta de trabalho. Quanto mais flexibilidade na oferta de trabalho houver, mais risco os indivíduos tendem a tomar, pois a qualquer momento há a possibilidade de gerar mudança nos valores de sua riqueza por meio da mudança de trabalho ofertado (tempo trabalhado). Os planos de benefícios foram classificados como mais maduros com um indicador que reflete a proporção de assistidos em relação à população do plano em cada período analisado, já o perfil de investimento foi definido com um indicador que reflete a proporção de ativos de risco (ações e títulos privados) sobre os ativos totais.

O estudo também pretendeu observar se o perfil de risco varia significativamente entre as modalidades de planos e o patrocínio predominante, como características qualitativas dos planos, esses fatos não são previstos pela teoria, mas são passíveis de análise, principalmente pela falta de referências que abordem o tema. 
Outra pergunta que o estudo buscou responder foi se os planos com perfil de investimento menos arriscado têm um melhor balanceamento atuarial per capita. Como a teoria prediz que planos mais maduros tendem a tomar menos risco, esperando essa relação, convém analisar se esses planos de benefícios são mais equilibrados, visto que estariam menos sujeitos a riscos de crédito e mercado que influenciam o valor de seus ativos.

A fim de responder às perguntas propostas, o estudo utilizou-se das bases de dados atuariais, cadastrais, de investimento e populacionais dos planos de benefícios das EFPC de 2008 a 2014, tendo como ponto de partida a base de dados atuarial.

O estudo se divide em seis capítulos, sendo esta introdução o primeiro deles. O Capítulo 2 buscou fazer uma contextualização das EFPC e dos planos de benefícios administrados por elas de maneira mais detalhada, mostrando dados recentes do sistema e algumas características particulares da previdência complementar fechada brasileira. O Capítulo 3 fez a revisão bibliográfica da teoria do ciclo de vida, sua aplicação às finanças e ao capital humano, buscando trazê-las para a realidade dos planos de benefícios, além de descrever alguns estudos empíricos internacionais sobre o tema. O Capítulo 4 abordou de forma mais detalhada e descritiva a base de dados utilizada e o método econométrico de análise. O Capítulo 5 tratou dos resultados encontrados e algumas discussões e, finalmente, o Capítulo 6 englobou as considerações finais do estudo proposto. Sinteticamente, podemos concluir que o perfil de investimento dos planos de benefícios não parece ter correlação com sua maturidade, conforme será detalhado no trabalho.

\section{AS EFPC E SEUS PLANOS DE BENEFÍCIOS}

Neste Capítulo, serão mais exploradas as características da previdência complementar fechada e seus planos de benefícios dentro do sistema previdenciário brasileiro.

\subsection{Contextualização das entidades fechadas de previdência complementar no sistema previdenciário brasileiro}

Dentro do RPCA, as entidades abertas de previdência complementar (EAPC), sociedades anônimas com fins lucrativos, administram planos de benefícios que podem ser oferecidos a qualquer pessoa e estão submetidas à supervisão da Superintendência de Seguros Privados (Susep), autarquia vinculada ao Ministério da Fazenda. 
Já quando se trata do RPCF, as EFPC administram planos de benefícios com adesão restrita a um público específico e estão submetidas à supervisão e regulamentação da Superintendência Nacional de Previdência Complementar (PREVIC), autarquia de natureza especial vinculada ao Ministério da Previdência Social. Como o enfoque deste estudo está nos planos de benefícios dessas EFPC, toda análise passará a se centrar neles.

As EFPC, popularmente conhecidas como fundos de pensão, são pessoas jurídicas de direito privado, constituídas como fundações ou sociedades civis, sem fins lucrativos e que têm como objetivo principal administrar planos de benefícios, por meio do recebimento de contribuições, aplicação de recursos e pagamento de benefícios previdenciários (Pinheiro, 2007).

A adesão aos planos de benefícios administrados pelas EFPC se restringe aos empregados de uma empresa ou grupo de empresas, aos servidores da União, Estados, Distrito Federal e Municípios $^{8}$, quando esses forem patrocinadores do plano e aos associados ou membros de pessoas jurídicas de caráter profissional, classista ou setorial, quando se tratar de instituidores. O regime é fechado a um público alvo específico, identificado com um vínculo de trabalho ou associativo 9 . Quando o vínculo é em função da relação de trabalho, os planos são patrocinados, contando com receitas em forma de contribuições dos participantes e patrocinadores, já quando o vínculo é associativo, normalmente, só há contribuições dos participantes do plano.

Ainda em relação à contextualização das EFPC dentro do sistema de previdência complementar brasileiro, cabe apontar que a estrutura básica de governança de cada entidade é composta por um conselho deliberativo, diretoria executiva e conselho fiscal. Ao conselho deliberativo, como instância decisória, compete a definição das diretrizes gerais da EFPC, à diretoria-executiva compete a execução e o gerenciamento das políticas e diretrizes definidas pelo conselho deliberativo e ao conselho fiscal compete a execução do controle interno das operações da EFPC.

\footnotetext{
${ }^{8}$ No caso dos governos subnacionais, quando o regime de previdência complementar dos servidores públicos já houver sido implementado no ente da federação. Os servidores da União vinculados aos poderes executivo e legislativo podem contribuir para os planos da Fundação de Previdência Complementar do Servidor Público Federal desde (Funpresp Exe) 04/02/2013. Já os servidores do judiciário e ministério público federal podem contribuir para o plano da Funpresp Jud desde dezembro de 2013.

${ }^{9}$ A Resolução CNPC no 18, de 30 de março de 2015, estendeu a possibilidade de disponibilização dos planos de benefícios de instituidores aos seus membros pessoas físicas vinculadas direta ou indiretamente aos instituidores, seus cônjuges e dependentes.
} 
As exigências legais em relação à composição dos órgãos de governança das EFPC variam de acordo com a natureza do patrocinador. Para aquelas que possuem planos patrocinados por entidades públicas os requisitos legais são mais restritivos, por exemplo, o conselho deliberativo tem, no máximo, seis membros, sendo três eleitos pelos participantes e assistidos ${ }^{10}$ e os três restantes indicados pelo(s) patrocinador(es) do plano, já o conselho fiscal deve ter no máximo quatro membros, sendo dois eleitos pelos participantes e assistidos e os outros dois nomeados pelo(s) patrocinador(es). Os mandatos tanto dos conselheiros deliberativos quanto dos conselheiros fiscais são fixos e duram quatro anos. A diretoria executiva das EFPC que possuem planos patrocinados por entidades públicas deve possuir, no máximo, seis membros, os quais possuem mandato definido no estatuto da EFPC e são nomeados e destituídos pelo conselho deliberativo. No que concerne às EFPC que administram planos patrocinados por empresas privadas, a exigência legal é que pelo menos um terço dos conselhos deliberativo e fiscal seja composto por membros escolhidos por participantes e assistidos.

Importante destacar a questão das regras de governança, pois em recente estudo Silva (2015) destaca que a proximidade da gestão das EFPC com seus patrocinadores, principalmente os de natureza pública, pode ser perversa pela potencial influência político-partidária nas nomeações da diretoria executiva e dos conselhos (deliberativo e fiscal) das EFPC. Silva (2015) aponta falha de governança privada nas EFPC, e, segundo seu diagnóstico, tal falha é explicada pelo conflito de interesses dos dirigentes e dos representantes de participantes/assistidos e de patrocinadoras. Silva aponta como possível solução maiores neutralidade e blindagem política dos diretores das EFPC que administram planos do setor público, pois em um ambiente político de convergência entre governo/estatais e representantes de participantes/assistidos, os possíveis conflitos de interesse se tornam mais agravados.

Após a contextualização das EFPC e sabendo que elas existem para administrar e executar planos de benefícios previdenciários, passa-se agora para a descrição dos planos atualmente administrados, ressaltando sua importância e tamanho no sistema de previdência nacional e na economia brasileira.

${ }^{10}$ Assistidos são todos aqueles que se encontram em gozo de benefícios dentro de um determinado plano. 


\subsection{Os planos de benefícios das EFPC: tipos de benefícios, modalidades e características gerais}

Antes da discussão sobre as modalidades de planos de benefícios oferecidos pelas EFPC, é importante que se entendam os tipos de benefícios pagos pelos planos, os quais são definidos como: benefícios programados e benefícios de risco.

Segundo Pinheiro (2007), os benefícios programados são aqueles previsíveis no regulamento do plano de benefícios ${ }^{11}$, visto que há uma data certa para início de sua fruição. Como exemplo, podem-se citar os benefícios por tempo de contribuição ou por idade. Já os benefícios de risco são aqueles em que a previsão da data de início de pagamento não é possível nos termos do regulamento do plano, visto que seu pagamento está vinculado à ocorrência de um evento aleatório, como exemplo, tem-se as pensões por morte e os benefícios de invalidez.

Os benefícios programados são o fator determinante para classificação dos planos pela legislação de previdência complementar atualmente em vigor nas seguintes modalidades: benefício definido (BD), contribuição variável (CV) e contribuição definida (CD).

Os planos de modalidade BD são aqueles cujos benefícios programados têm seu valor ou nível previamente estabelecido e seu custeio determinado atuarialmente, ou seja, o valor do benefício é uma variável independente, estabelecida no regulamento do plano, e a contribuição é uma variável dependente e determinada anualmente pelo plano de custeio, o qual deve ser suficiente para financiar os benefícios futuros. $\mathrm{O}(\mathrm{s})$ benefício(s) programado(s) em um plano BD é(são) normalmente uma porcentagem do valor do salário recebido pelo participante na fase laboral e tem característica vitalícia. Pode-se, então, definir algumas características dos planos na modalidade BD, quais sejam:

a) o patrimônio acumulado com contribuições de participantes e patrocinadores não é alocado em uma conta individual, mas sim em uma conta coletiva;

b) o valor do benefício é conhecido previamente, seguindo uma regra estabelecida e independe dos recursos constituídos;

\footnotetext{
${ }^{11} \mathrm{O}$ regulamento do plano de benefícios consiste num conjunto de dispositivos jurídicos que definem as condições, direitos e obrigações do participante, do patrocinador ou instituidor do plano de benefícios.
} 
c) existe mutualismo, pois a avaliação atuarial é feita em função da coletividade de participantes e assistidos pertencentes ao plano;

d) a contribuição é indefinida e ajustada ao longo do tempo, conforme a rentabilidade financeira e o dimensionamento do passivo, retratados pelos cálculos atuariais; e

e) eventuais resultados positivos ou negativos advindos de oscilações nas hipóteses atuariais, demográficas e econômicas são compartilhados entre participantes, assistidos e patrocinadores do plano.

Os planos na modalidade CD são aqueles cujos benefícios programados têm seu valor permanentemente ajustado ao saldo de conta mantido em favor do participante, inclusive na fase de percepção de benefícios, considerando o resultado líquido de sua aplicação, os valores aportados e os benefícios pagos. Conforme Pinheiro (2007), a variável dependente de um plano CD é o benefício e a variável independente é a contribuição, ou seja, o benefício fica indefinido e varia de acordo com o nível do patrimônio existente que depende da rentabilidade alcançada pelos investimentos realizados com os recursos das contribuições provenientes dos participantes e patrocinadores. Como não há mecanismos de ajuste de contribuição ao longo do tempo em planos $\mathrm{CD}$, e o benefício futuro é uma variável de valor desconhecido, o risco financeiro das aplicações e eventuais aumentos de longevidade dos participantes e assistidos dos planos são riscos não cobertos. Esses planos funcionam como uma poupança programada, na qual o saldo acumulado até a data de aposentadoria normalmente se transforma em um benefício mensal, podendo ou não ser vitalício, com ou sem garantia de reajustes, dependendo do regulamento do plano.

Finalmente, os planos de modalidade CV são aqueles cujos benefícios programados conjugam características das modalidades BD e CD. Os planos podem oferecer benefícios vitalícios, benefícios por tempo determinado ou uma grande fração do saldo acumulado pago de uma só vez. Um plano CV normalmente se comporta como um CD na fase de acumulação e, dependendo das regras do regulamento do plano e da escolha do participante em relação à forma de recebimento quando da elegibilidade a um benefício programado, apresenta características de plano BD na fase de recebimento dos benefícios.

Segue a distribuição dos planos de acordo com tipo de plano e modalidade, conforme dados divulgados pela Previc e posicionados em dezembro de 2014: 
Tabela 1 - Distribuição dos planos por tipo e modalidade

\begin{tabular}{c|c|c|c|c}
\hline \multicolumn{2}{c|}{ Quantidade de planos por tipo } & \multicolumn{3}{c}{ Quantidade de planos por modalidade } \\
\hline Patrocinado & Instituído & BD & CV & CD \\
1.039 & 62 & 327 & 361 & 413 \\
\hline
\end{tabular}

Fonte: Elaboração própria a partir dos dados do Informe Estatístico $4^{\circ}$ trimestre de 2014 - PREVIC

Fato importante de ser trazido à tona e já apontado por Pinheiro (2007) é que a partir da década de 90 foi registrado um decréscimo na importância dos planos de BD em favor de planos $\mathrm{CD}$, tanto nacional como internacionalmente. Dentre as possíveis explicações para tal migração, destaca-se a aversão ao risco por parte das patrocinadoras dos planos, devido à incerteza na predição dos recursos requeridos a serem constituídos para o pagamento dos benefícios previdenciários. Destaque-se que cerca de $66 \%$ dos planos BD demonstrados na Tabela 1 encontram-se fechados a novas adesões, sendo as modalidades CD e CV o futuro da previdência complementar fechada brasileira.

\section{A TEORIA DO CICLO DE VIDA NO CONTEXTO DOS PLANOS DE BENEFÍCIOS}

Como as EFPC existem para administrar planos de benefícios e esses são formas de poupar quando jovem para gastar quando idoso, tal entendimento pode ser remetido às teorias econômicas de ciclo de vida. Neste capítulo iremos, inicialmente, fazer uma revisão dessas teorias. Na segunda subseção, trataremos das avaliações empíricas de como essas teorias podem se aplicar aos planos de benefícios e, principalmente, no que concerne aos seus investimentos.

\subsection{Revisão bibliográfica das teorias do ciclo de vida e das finanças do ciclo de vida}

A teoria do ciclo de vida foi desenvolvida por Franco Modigliani e Richard Brumberg em meados anos 1950 e é uma das principais teorias de consumo e poupança já desenvolvidas na economia. A motivação para a teoria do ciclo de vida é a evolução da riqueza ao longo da vida de um indivíduo: os jovens têm pouca riqueza, os indivíduos na meia-idade possuem mais riqueza que os jovens e o pico da riqueza é atingido pouco antes de o indivíduo se aposentar.

A teoria é baseada na ideia de que os indivíduos fazem escolhas racionais acerca de quanto consumir a cada idade, tendo como restrição apenas os recursos disponíveis durante o 
ciclo de suas vidas. Por conta do acúmulo e deterioração gradual dos ativos ao longo da vida, os indivíduos que estão no mercado de trabalho têm a capacidade de fazer provisões para suas aposentadorias e, de forma mais geral, moldam seus padrões de consumo às suas necessidades em diferentes idades, independentemente da renda em cada uma delas. Assume-se, para cada indivíduo, que crescimentos nos recursos durante o ciclo da vida, levam a crescimentos proporcionais no consumo em todos os períodos. Tal suposição pode ser traduzida como uma proporcionalidade do consumo em relação à renda média ao longo da vida do indivíduo ${ }^{12}$. A hipótese de o consumo ser entendido como constante ao longo da vida aponta para o fato de que o indivíduo não toma decisões com base em sua renda corrente, mas com base em sua renda no decorrer da vida, poupando mais em períodos de renda alta e despoupando mais em períodos de renda mais baixa, com a finalidade de manter seu consumo constante. Pelo fato de não haver fluxo de renda do trabalho na aposentadoria, o indivíduo tende a despoupar, desfazendo-se da riqueza acumulada para financiar seu consumo. Dessa forma, a riqueza máxima do indivíduo é atingida na aposentadoria.

A teoria do ciclo de vida também proporcionou implicações macroeconômicas sobre o consumo e poupança agregados. Em uma economia com população e produto nacional bruto (PNB) constantes ao longo do tempo não haveria poupança, já que a poupança dos mais jovens corresponderia exatamente ao consumo dos aposentados. Já para uma economia em que há crescimento populacional, uma maior quantidade de jovens em relação aos aposentados faria com que a poupança agregada líquida fosse positiva. Da mesma forma, se a renda de uma economia está crescendo, os mais jovens estarão poupando em uma escala maior do que aquela em que os aposentados estão consumindo, causando aumento na poupança agregada líquida da mesma forma que o crescimento populacional e, quanto maior o crescimento dessa renda, maior a taxa de poupança agregada. Na realidade o fato determinante do crescimento da poupança agregada é o crescimento da renda total, independentemente de ser impulsionada pelo crescimento populacional ou pela renda per capita. Dessa maneira, pode-se concluir que o consumo agregado depende em parte da composição etária da população, da idade média de aposentadoria e da existência ou não de uma previdência social (Famá et al, 1998).

\footnotetext{
${ }^{12}$ Como os indivíduos valorizam o presente mais que o futuro, a tendência seria o consumo ir decaindo ao longo do tempo, essa hipótese de consumo constante é apenas uma simplificação, que não altera a essência do argumento.
} 
Tendo como ponto de partida a teoria original do ciclo de vida, suas hipóteses e conclusões elencadas, passa-se então para seus desdobramentos no campo das finanças, com aplicabilidade direta à realidade do objeto de estudo deste trabalho, qual seja: os planos de benefícios previdenciários administrados pelas EFPC e suas características esperadas ao longo do seu ciclo de existência.

No que concerne à alocação de ativos a teoria de finanças desenvolveu diversas abordagens, a grande maioria delas busca mostrar como se dá a escolha ótima de uma carteira, como o famoso modelo de Markowitz (1952), que analisa o trade-off entre risco e retorno, e pode ser considerado precursor da teoria moderna das finanças. Como a teoria do ciclo de vida é um modelo que leva em consideração aspectos e escolhas intertemporais (ou dinâmicas), descreveremos a seguir modelos de finanças que incorporam tais decisões.

O modelo contínuo de Merton (1990) leva em consideração vários horizontes temporais, tais como: o horizonte de planejamento, o horizonte de decisão e o horizonte de negociação. O horizonte de planejamento corresponde ao período até a data de aposentadoria do indivíduo, portanto quanto maior a idade de uma pessoa, menor é seu horizonte de planejamento. Já o horizonte de decisão compreende o período entre as decisões de realocação de portfólio, tal período está sobre o controle das decisões dos indivíduos com algumas limitações. Alguns indivíduos reveem seus portfólios frequentemente, outros apenas os reveem em intervalos irregulares de tempo devido a fatores endógenos ${ }^{13}$ ou exógenos ${ }^{14}$. Finalmente, o horizonte de negociação é o intervalo de tempo mínimo para que os investidores revejam seus portfólios e não está sob controle do indivíduo, visto que é determinado pela estrutura dos mercados na economia.

Objetivando trazer o modelo contínuo de Merton mais próximo da realidade, visto que uma de suas hipóteses é de que os investidores não possuem renda derivada do trabalho, Bodie, Merton e Samuelson (1992) adicionaram uma terceira variável de escolha ao modelo: a quantidade de trabalho que as pessoas decidem ofertar. Neste modelo, os indivíduos começam com uma dotação inicial de riqueza financeira e capital humano (que permite gerar renda derivada do trabalho). Os valores de mercado dos dois componentes da riqueza (financeira e capital humano) mudam constante e estocasticamente, a taxa de salário (retorno sobre o capital

\footnotetext{
${ }^{13}$ Tais como: casamento, divórcio, paternidade/maternidade, recebimento de herança.

${ }^{14} \mathrm{Um}$ aumento ou queda de preço repentino nos ativos que compõem o portfólio do indivíduo.
} 
humano) é positivamente correlacionada com o retorno de mercado dos ativos negociáveis. A cada período os indivíduos determinam o quanto vão consumir, a proporção de sua riqueza financeira a ser investida em ativos de risco e a fração da renda máxima possível obtida do trabalho a ser gasta com lazer, com a finalidade de maximizar a utilidade esperada ao longo da vida. Os resultados do modelo sugerem que a fração de riqueza financeira do indivíduo investida em ativos de maior risco deve diminuir ao longo dos anos por duas razões. A primeira delas deriva do fato de o capital humano ser menos arriscado que ativos de risco (como ações e títulos privados) e esse mesmo capital humano diminui como proporção da riqueza total do indivíduo conforme os anos passam. A segunda razão deriva da capacidade que os indivíduos possuem de flexibilizar sua oferta de trabalho, de forma que quanto mais flexibilidade houver, mais investimento em ativos de risco existirá, pois a qualquer momento há a possibilidade de gerar mudança nos valores da riqueza financeira por meio da mudança da quantidade de tempo trabalhado. Assim, essa flexibilidade na oferta de trabalho funciona como uma proteção a investimentos com baixos retornos. Se os trabalhadores jovens têm maior capacidade de alterar sua oferta de trabalho do que os trabalhadores mais velhos, então a proporção de ativos arriscados em seus portfólios deve diminuir conforme a idade avança.

Dessa forma, os modelos de Merton e Bodie et al nos mostram, em primeiro lugar, que os indivíduos tendem a poupar quando jovens e a despoupar quando velhos. O papel das EFPC como intermediárias torna mais fácil a implementação das decisões de consumo dos agentes econômicos (e, consequentemente, de poupança) ao longo de suas vidas. Também vimos que, quanto mais próximos da aposentadoria, mais conservador tende a ser o portfólio dos indivíduos.

\subsection{Revisão dos estudos empíricos da teoria do ciclo de vida aplicada aos investimentos dos planos de benefícios}

Alguns estudos empíricos derivados das hipóteses da teoria do ciclo de vida aplicados aos planos de benefícios de fundos de pensão foram encontrados na literatura internacional. Já para o caso brasileiro, não foi encontrado estudo empírico com uma base de dados representativa como nos casos internacionais, dessa maneira, espera-se que o presente estudo contribua com a 
literatura nacional, principalmente pelos dados empíricos aqui levantados, descritos e testados, de forma a trazer luz e interesse ao tema, tão pouco explorado até o momento.

Bikker et al (2009) realizaram estudo empírico com uma base de dados posicionada no final de 2007 (corte transversal), relativo a 378 fundos de pensão holandeses, no qual foi examinado o impacto da distribuição etária dos participantes na alocação de ativos dos planos de benefícios. O objetivo do estudo foi averiguar se de fato as políticas de investimento dos fundos de pensão dependiam da idade de seus participantes. $\mathrm{O}$ argumento da dependência da idade na alocação ótima em ativos de risco deriva dos modelos de ciclo de vida de investimento e poupança, pois tais modelos apresentam resultados no sentido de que a proporção de ativos financeiros investidos em ativos de risco deveriam diminuir ao longo do ciclo de vida e, como resultado, aumentaria a proporção de ativos financeiros investidos em títulos públicos (ativos de baixo risco). O principal argumento, conforme vimos no modelo de Bodie et al (1992) é que os trabalhadores mais jovens possuem maior capital humano que os mais velhos e, por isso, possuem maior capacidade de diversificar e diluir os riscos ao longo de sua vida (e de seu capital humano), desde que a correlação entre a renda do trabalho e os retornos do mercado financeiro seja assumida como muito pequena.

O estudo de Bikker et al contextualiza a realidade dos fundos de pensão holandeses, informando que tais fundos embasam seu nível de cobertura e decisões de alocação no compartilhamento de risco intergeracional. Tal compartilhamento aumenta a capacidade de tomar risco, pois os riscos são compartilhados não apenas por contemporâneos de uma mesma coorte populacional, mas com futuras gerações, visto que são planos BD. O artigo explicita duas visões opostas para alocação de risco ótima nos fundos de pensão: a estratégia de longo prazo, que recomenda a aquisição de ativos mais arriscados, e a estratégia de títulos públicos, que recomenda a aquisição de ativos menos arriscados. A estratégia de longo prazo considera o fato de os fundos de pensão terem de arcar com o pagamento dos benefícios atuais e futuros e, como os riscos das várias categorias de ativos são diferentes para cada horizonte de tempo, as escolhas de um portfólio de longo prazo divergem daquelas de curto prazo. Como o risco depende do (ou varia com o) horizonte temporal, os investidores de longo prazo se beneficiam das diversificações feitas entre as classes de ativos ao longo do tempo. Os instrumentos de mercado são relativamente seguros para os investidores de curto prazo, ao passo que para os investidores de longo prazo, por conta das taxas de juros de curto prazo serem incertas, há risco de 
reinvestimento. Adicionalmente, a estratégia de títulos públicos argumenta que os passivos previdenciários possuem características bem parecidas com as dos títulos públicos, sendo que o valor de tais passivos é igual ao valor de um portfólio de títulos públicos, com fluxos casados no tempo e no valor dos benefícios prometidos.

$\mathrm{O}$ artigo prossegue argumentando que uma estratégia de investimento que preveja descasamento entre ativos e passivos pode melhorar o compartilhamento de risco intergeracional, pois os fundos de pensão buscam um prêmio de risco nos seus ativos, com o objetivo de não ter que arcar com todo o custo econômico dos benefícios pactuados.

A lógica por trás dos modelos ótimos de ciclo de vida de investimento e poupança é que os trabalhadores mais jovens, por possuírem mais capital humano que trabalhadores mais velhos, podem diversificar seus riscos de investimento, assumindo que tal capital humano é pouco arriscado, o que leva à correlação negativa entre idade e exposição a ativos mais arriscados.

Segue o modelo linear estimado pelos autores:

- $\quad$ Alocação estratégica em ativos de risco ${ }_{i}=\beta_{0}+\beta_{1}$ idade total $_{i}+$ $\beta_{2} \ln (\text { tamanho do fundo })_{i}+\beta_{3}$ taxa de cobertura ${ }_{i}+\beta_{4}$ riqueza pessoal $_{i}+\beta_{5} B D+$ $\beta_{6} F P G P+\beta_{7} F P I+u_{i}$

A variável investigada é a alocação estratégica em ativos mais arriscados, que busca mensurar a proporção de ativos de risco no portfólio total. É pertinente apontar que a variável estudada pelo modelo de Bikker et al não corresponde a alocação real em ativos de risco, mas sim à intenção de alocação contida na política de investimentos de cada fundo de pensão. Já nas variáveis explicativas há a idade média de todos os participantes de cada plano, o tamanho do fundo de pensão, o qual tende a refletir maior grau de profissionalismo na gestão dos investimentos, a taxa de cobertura (ativos sobre passivos), riqueza pessoal, que corresponde ao total de ativos de um fundo per capita; e mais um conjunto de três variáveis qualitativas, que descrevem características dos fundos de pensão ${ }^{15}$. Os fundos de pensão em que os participantes possuíam idade média total maior, de fato possuíam menor exposição a ativos mais arriscados, como prevê a teoria de investimento e poupança do ciclo de vida. Outro resultado interessante revelado pelo estudo empírico foi que a idade média dos participantes ativos (ou seja, aqueles que ainda estão trabalhando) tem um impacto muito maior nos investimentos do que a idade

\footnotetext{
15 Tais como variáveis dummy que indicam se a modalidade do plano é do tipo benefício definido (BD), se são fundos de pensão de grupos profissionais (FPGP), ou se são fundos de pensão de indústrias (FPI).
} 
média total (que inclui os aposentados). Por fim, o estudo também conclui que os fundos de pensão maiores apresentam muito mais fortemente o efeito da idade na alocação de seus ativos, se ajustando melhor à teoria do ciclo de vida.

Outro estudo empírico pesquisado foi o realizado por Andonov et al (2014), o qual contou com uma base de dados muito mais abrangente e robusta, contento informações de 804 fundos de pensão ${ }^{16}$ dos Estados Unidos, Canadá e Europa (principalmente da Holanda e Reino Unido) de 1993 a 2010. A pesquisa teve foco nos diferentes incentivos regulatórios entre os países, principalmente no que concerne à definição da taxa de desconto dos passivos atuariais e eventuais efeitos na alocação dos ativos, a fim de testar se o comportamento dos fundos de pensão estava em linha com a teoria econômica.

Os modelos teóricos da teoria do ciclo de vida do capital humano afirmam que a alocação estratégica de ativos dos fundos de pensão deveriam ser uma função da maturidade, do crescimento salarial e da proteção contra inflação, e que tais variáveis deveriam ter o mesmo efeito em todos os fundos de pensão, independentemente do ambiente regulatório, região geográfica ou tipo de plano.

A teoria do ciclo de vida do capital humano sugere que, no longo prazo, o crescimento da renda agregada proveniente do trabalho e o retorno sobre ativos de risco são positivamente correlacionados, mesmo que no curto prazo sua correlação seja muito baixa; tal fato faz com que as obrigações relacionadas a aposentados e trabalhadores mais velhos se comportem como títulos públicos e por isso possam ser avaliadas com tais. Adicionalmente, as obrigações relativas a trabalhadores mais jovens se comportam mais como ações, devido ao risco associado ao salário futuro, daí o argumento de que a proporção da alocação dos investimentos em ativos mais arriscados deve ser relacionada à proporção de participantes ativos em um fundo de pensão, pois os benefícios são normalmente vinculados aos salários, que por sua vez são positivamente correlacionados com os retornos do mercado de capitais no longo prazo.

Já no que concerne à definição da taxa de desconto dos passivos atuariais, a teoria financeira sugere que os fluxos de benefícios futuros devem ser descontados a uma taxa que reflita seu risco inerente, especialmente em relação à covariância de tais fluxos com riscos precificáveis. No caso dos fundos de pensão, o principal risco associado ao passivo é se os benefícios prometidos de fato serão pagos de forma integral no futuro. O estudo descreve os

\footnotetext{
${ }^{16}$ Todos os fundos de pensão constantes do estudo possuem planos na modalidade benefício definido.
} 
diferentes ambientes regulatórios para definição da taxa de desconto destacando que os fundos de pensão públicos nos EUA são um grupo sui generis dentre os pesquisados, pois são os únicos para os quais a regra para definição da taxa se baseia na expectativa futura de longo prazo de retorno dos ativos. Segundo argumentam os autores, essa discricionariedade concedida aos fundos de pensão públicos estadunidenses gera incentivos para uma maior alocação em ativos de risco, pois com uma expectativa futura de maior retorno, suas taxas de desconto do passivo atuarial podem ser maiores, gerando estimativas menores aos passivos atuarias, mesmo que a natureza das obrigações não mude em nada. Os fundos de pensão privados estadunidenses estão submetidos a uma regulação que permite que suas obrigações atuariais sejam descontadas com base em títulos corporativos de longo prazo bem avaliados no que concerne ao risco de crédito.

No caso dos fundos de pensão canadenses, os autores apontam que não há diferença na regulação entre fundos públicos ou privados e que a definiç̧ão da taxa de desconto das obrigações atuariais está vinculada aos retornos de mercado de títulos corporativos de alta qualidade.

Por fim, os autores ainda informam que as regras para definição da taxa de desconto dos fundos de pensão holandeses tem por base a estrutura a termo das taxas de juros nominais livres de risco; os fundos de pensão privados do Reino Unido utilizam os rendimentos de títulos classificados como AA para o desconto dos seus passivos atuariais e os públicos utilizam a taxa de $3 \%$ ao ano, a qual reflete a expectativa de crescimento do PIB no longo prazo.

O modelo estimado pelos autores para investigar a alocação estratégica em ativos de risco foi uma regressão de dados de painel, conforme explicitado abaixo:

- $\quad \%$ Ativos de risco $_{i, t}=\beta_{0}+\beta_{1} \%$ aposentados $_{i, t}+\beta_{2} X_{i, t}+\beta_{3} Y D_{t}+\beta_{4} F E_{i}+u_{i, t}$

Da mesma forma que o estudo realizado por Bikker et al a variável aqui investigada reflete a política de investimentos de cada fundo de pensão, a qual informa a intenção de estratégica de investimento e não a alocação real, que pode ser afetada por movimentos de mercado devido a expectativas de custos de transação de reequilíbrio de carteiras. O modelo também contou com a inserção da porcentagem de participantes aposentados em relação ao total de participantes, variáveis de controle como tamanho de fundo de pensão, proteção contra inflação, tipo de fundo de pensão (público ou privado) e dummies para os diferentes anos com o intuito de explicar a alocação em ativos mais arriscados.

Como o estudo também investigou a escolha das taxas de desconto dos passivos atuariais, segue outro modelo estimado pelos autores: 
- $\quad$ Taxa de desconto ${ }_{i, t}=\beta_{0}+\beta_{1} \%$ aposentados $_{i, t}+\beta_{1} \%$ ativos de risco $_{i, t}+\beta_{3} X_{i, t}+\beta_{3} Y D_{t}+$ $\beta_{4} F E_{i}+u_{i, t}$

Como variáveis explicativas para o segundo modelo foram inseridas: a porcentagem de participantes aposentados de cada fundo de pensão, a porcentagem de alocação em ativos mais arriscados, além de outras variáveis de controle como tamanho de fundo de pensão, proteção contra inflação e tipo de fundo de pensão (público ou privado).

Os resultados encontrados no estudo estão em linha com a teoria econômica do ciclo de vida do capital humano, menos para os fundos de pensão públicos estadunidenses que apresentaram reações opostas ao amadurecimento de seus participantes e ao declínio dos rendimentos em títulos públicos verificados em todos os países da amostra analisada. Os autores concluem que o comportamento singular dos fundos de pensões estadunidenses pode ser explicado pelos incentivos regulatórios aos quais eles estão expostos, principalmente no que concerne à discricionariedade concedida para o estabelecimento da taxa de desconto dos passivos atuariais, segundo a regulação vigente a taxa de desconto deve ser igual a expectativa de retorno dos ativos. Isso significa que investindo em ativos com maior risco os fundos de pensão públicos dos EUA podem adotar taxas de desconto maiores, fazendo com que aparentem ter uma posição de cobertura ${ }^{17}$ irreal, embora tal posição não altere em nada as características dos seus passivos. Ademais, o estudo também documentou que para os fundos públicos estadunidenses mais maduros as taxas de desconto foram ainda mais elevadas, além desses fundos mais maduros e com taxas de desconto mais elevadas terem registrado uma performance financeira muito aquém de seus benchmarks ${ }^{18}$. Tais resultados, segundo os autores, comprovam que os comportamentos avessos à teoria econômica não são baseados em oportunidades de investimentos, mas sim em incentivos de regulação que levam esses fundos de pensão públicos a reportarem passivos atuariais menores.

Em contrapartida, os fundos de pensão canadenses, europeus e os fundos de pensão privados estadunidenses, de acordo com a teoria econômica, registraram declínio em suas taxas de desconto quando as taxas de juros de suas economias registraram queda, além de terem

\footnotetext{
${ }^{17} \mathrm{O}$ indicador de cobertura, também referido como indicador de solvência, corresponde à soma dos ativos sobre a soma dos passivos de um plano de benefícios em um determinado período.

18 Os autores também informam que, devido à proteção e garantia constitucional e jurisprudencial dada aos benefícios, o fato de os investimentos terem uma performance baixa não gera menores gastos administrativos nos fundos de pensão públicos estadunidenses, o que faz os resultados serem mais preocupantes.
} 
registrado declínio nos investimentos em ativos mais arriscados quando foi registrado crescimento no amadurecimento populacional de seus participantes. $\mathrm{O}$ estudo encerra com a proposta de igualar as regulações tanto para os fundos de pensão públicos e privados dos EUA, visto que o propósito máximo de qualquer fundo, independentemente do seu tipo, é prover benefícios que sejam financeiramente acessíveis e seguros aos seus participantes.

\section{BASE DE DADOS E MÉTODOS}

Este capítulo explicará a base de dados utilizada com descrição detalhada de alguns dos fatos estilizados aqui tratados. A primeira subseção define alguns conceitos, a segunda apresenta gráficos e alguns comentários em relação aos dados e a terceira detalha a técnica econométrica de dados de painel utilizada para análise.

\subsection{Base de dados utilizada}

\subsubsection{Dados atuariais}

Na esfera atuarial dos planos de benefícios há informações relativas às hipóteses utilizadas para o dimensionamento do passivo do plano e tais informações serão o ponto de partida da análise pretendida neste estudo.

Os dados atuariais, extraídos dos demonstrativos atuariais ${ }^{19}$ consistem nos resultados das avaliações atuariais anuais, que as EFPC enviam compulsoriamente à Previc, conforme prevê o art. 22 da Lei Complementar 109, de 29 de maio de 2001:

Art. 22. Ao final de cada exercício, coincidente com o ano civil, as entidades fechadas deverão levantar as demonstrações contábeis e as avaliações atuariais de cada plano de benefícios, por pessoa jurídica ou profissional legalmente habilitado, devendo os resultados ser encaminhados ao órgão regulador e fiscalizador e divulgados aos participantes e aos assistidos.

(...)

${ }^{19}$ Os dados de 2008 a 2010 foram retirados dos Demonstrativos de Resultado de Avaliação Atuarial (DRAA) e os de 2011 a 2014 das Demonstrações Atuariais (DA), ambos de envio compulsório à Previc. 
A quantificação das obrigações de um plano de benefícios tem como premissas principais as tábuas biométricas, as quais expressam as probabilidades de ocorrência de um evento tal como mortalidade geral, mortalidade de inválidos, entrada em invalidez e morbidade para um determinado número de pessoas expostas a tais riscos em um período específico. Além disso, as demonstrações atuariais (DA) trazem informações acerca do número de participantes ativos vinculados a um plano, dos patrocinadores, do número de benefícios concedidos, do valor médio de cada benefício, dos fundos previdenciais ${ }^{20}$, do custo de cada benefício e as hipóteses atuariais, financeiras e econômicas utilizadas nos cálculos (tais como taxa real anual de juros, indexador de reajuste dos benefícios, hipótese de rotatividade, etc ${ }^{21}$ ). Os resultados das avaliações atuariais objetivam dimensionar os compromissos dos planos de benefícios, aqui referidos como provisões matemáticas, as quais são calculadas a partir da seguinte diferença:

- $\quad P M=V A B F-V A C F$, onde

○ $\quad P M-$ representa as provisões matemáticas;

- $V A B F-$ consiste no valor atual dos benefícios futuros; e

○ $V A C F-$ consiste no valor atual das contribuições futuras.

Tem-se então que as provisões matemáticas de um plano de benefícios são as suas obrigações líquidas e são expressas por uma diferença de fluxos financeiro-atuariais projetados, trazidos a valor presente e recalculados anualmente, de acordo com a massa de participantes ativos e assistidos de um plano, a aderência das hipóteses e premissas atuariais utilizadas nas avaliações e, mais sensivelmente, de acordo com a performance financeira do plano, visto que tais provisões são descontadas de acordo com uma taxa real anual de juros (taxa de desconto atuarial).

\footnotetext{
${ }^{20}$ Segundo o "Guia Previc - Melhores Práticas Atuariais para Entidades Fechadas de Previdência Complementar", os fundos previdenciais são atuarialmente calculados e devem ser instrumentos de suavização de riscos aos quais um plano de benefícios está exposto. A constituição e a manutenção dos fundos previdenciais atuariais devem observar a estrutura técnica do plano de benefícios, sua fonte de custeio e destinação devem ser expressamente indicadas pelo atuário e sua finalidade deve guardar relação com um evento determinado ou com um risco identificado, avaliado e monitorado.

${ }^{21}$ De acordo com a lista constante das demonstrações atuariais as hipóteses atuariais são: composição de família dos pensionistas, indexador do plano (reajuste dos benefícios), taxa real anual de juros, tábua de mortalidade geral, tábua de entrada em invalidez, tábua de mortalidade de inválidos, tábua de morbidez, fator de determinação do valor real ao longo do tempo para o benefício do INSS, fator de determinação do valor real ao longo do tempo para os salários, fator de determinação do valor real ao longo do tempo para o benefício da entidade, hipótese de entrada em aposentadoria, hipótese sobre gerações futuras de novos entrados, hipótese sobre rotatividade, projeção de crescimento real do salário, projeção de crescimento real do maior benefício do INSS e projeção de crescimento real dos benefícios do plano.
} 
Existe uma parcela patrimonial de cada plano que é disponível para fazer frente às provisões matemáticas e tal parcela é denominada patrimônio de cobertura. Na planificação contábil padrão, mais especificamente quando se tem como referência o balanço patrimonial de um plano nos termos da legislação vigente ${ }^{22}$, o patrimônio de cobertura faz parte do patrimônio social dos planos de benefícios, da mesma forma que as provisões matemáticas. $\mathrm{O}$ patrimônio de cobertura de um plano corresponde à seguinte diferença:

- $\quad P C=A T-(E O+E C+F)$, onde

○ $\quad P C$ - representa o patrimônio de cobertura;

- $A T$ - consiste no ativo total do plano;

- $E O-$ refere-se ao exigível operacional do plano ${ }^{23}$;

- $E C$ - refere-se ao exigível contingencial do plano ${ }^{24}$;

- $F$ - consiste nos valores registrados em fundos previdenciais, de investimentos e administrativos.

Para obtenção do resultado de um plano em um determinado período calcula-se a diferença entre seu patrimônio de cobertura e suas provisões matemáticas ${ }^{25}$, neste trabalho denominaremos tal resultado como balanceamento atuarial.

Nesta dissertação, buscar-se-á explicar o comportamento do balanceamento atuarial ao longo dos anos de 2008 a 2014. Ressalte-se que o balanceamento atuarial analisado não é o valor absoluto da diferença entre o patrimônio de cobertura e as provisões matemáticas do plano, mas sim um valor per capita, sendo tal valor dividido pelo número total de participantes ativos e assistidos do plano para cada período analisado.

Com o intuito de tentar explicar o balanceamento atuarial dos planos de benefícios foi utilizada outra variável das demonstrações atuariais: a taxa real anual de juros, que é a taxa de desconto utilizada para trazer a valor presente as provisões matemáticas atuarialmente calculadas.

\footnotetext{
${ }^{22}$ Ver Resolução CNPC no 8, de 31 de outubro de 2011.

${ }^{23}$ Somatório dos compromissos de curto prazo já assumidos pela entidade, tais como benefícios a pagar, despesas administrativas a pagar, impostos e taxas a serem pagos, entre outros.

${ }^{24}$ Registram as provisões relativas a litígios da gestão previdencial e administrativa, incluindo as trabalhistas e fiscais, cujas decisões futuras podem gerar desembolso para o plano.

${ }^{25}$ Cabe esclarecer que os resultados dos planos de benefícios foram calculados com a provisões matemáticas brutas de provisões matemáticas a constituir registradas no passivo.
} 


\subsubsection{Dados de investimentos}

Os dados de investimentos referem-se à distribuição dos valores aplicados nos tipos de ativos que compõem a carteira de cada plano, de acordo com a classificação definida pela Resolução do Conselho Monetário Nacional no 3.792, de 24 de setembro de 2009, modificada pela Resolução $\mathrm{CMN} \mathrm{n}^{\circ}$ 4.275, de 31 de outubro de 2013. Os dados relativos à carteira de investimentos dos planos de benefícios são enviados ao órgão supervisor e fiscalizador mensalmente ${ }^{26}$, são denominados demonstrativos de investimento (DI) e são formados pela composição analítica das carteiras próprias, dos fundos de investimento e dos fundos de investimento em cotas de fundos de investimento dos quais a EFPC que administra o plano seja cotista direta ou indiretamente. Foram utilizados os dados relativos ao último mês de 2008 a 2014, para que o momento no qual os dados estão posicionados fosse coincidente com a data de referência das demonstrações atuariais (31/12).

Objetivando diferenciar os planos com uma carteira de investimentos considerada mais arriscada, foi criado um indicador de perfil de risco para cada plano de benefícios para atender às necessidades de análise deste trabalho, o qual buscou traduzir a proporção dos ativos considerados mais arriscados sobre os ativos totais de cada plano em cada período. Cabe aqui informar que o indicador aqui criado não é um dado enviado pelas EFPC, ele foi concebido para o trabalho em tela e os tipos de ativos considerados no indicador de perfil de risco foram:

- Ações; e

- Títulos privados.

A escolha das ações e dos títulos privados para identificar aqueles planos que possuíam um perfil de risco mais agressivo em determinado ano mostra alinhamento à teoria econômica das finanças, visto que seus valores como proporção da carteira de investimentos tendem a refletir alguns dos riscos inerentes a esses ativos, tais como risco de crédito e risco de mercado.

Dentro do grupo de ativos "Ações” encontram-se majoritariamente as ações ordinárias, ações preferenciais e certificados de depósitos de ações emitidos por sociedades anônimas. O grupo de ativos "Títulos privados" engloba principalmente debêntures, certificados de depósitos bancários e certificados de recebíveis imobiliários.

\footnotetext{
${ }^{26}$ Até o exercício de 2014, os dados de investimentos eram enviados com periodicidade trimestral.
} 
O perfil de investimento, informado pelo indicador de perfil de risco, também é uma das variáveis que será investigada. Quanto mais próximo de um for o indicador, maior é a alocação em ativos com maior risco e menor a alocação em ativos menos arriscados de um plano de benefícios, em um determinado período.

\subsubsection{Dados cadastrais}

Além dos dados atuariais, que mostram o passivo dos planos de benefícios e dos dados de investimentos que tratam da alocação e distribuição dos ativos da carteira dos planos, houve também utilização de dados cadastrais tais como a modalidade dos planos e a legislação aplicável a cada plano de acordo com o tipo de patrocinador. As modalidades dos planos de benefícios, conforme já tratado anteriormente, podem ser: benefício definido (BD), contribuição variável (CV) e contribuição definida (CD). Já no que concerne à legislação aplicável a cada plano, a classificação depende de suas patrocinadoras. Se há patrocínio predominante público ${ }^{27}$, o plano é regido de forma mais específica pela Lei Complementar $\mathrm{n}^{\circ} 108$ e de forma mais genérica pela Lei Complementar $n^{\circ} 109$, ambas de 29 de maio de 2001. Já se o plano possui patrocínio predominante privado, ele possui menos restrições legais e é regido apenas pela Lei Complementar $n^{\circ} 109$. Como estas informações são qualitativas, elas foram inseridas nos modelos como variáveis explicativas dummy ou binárias.

\subsubsection{Dados populacionais}

Para completar o conjunto da base de dados utilizada nesta investigação, foram utilizados dados populacionais dos planos para criação de um indicador com o número total dos participantes assistidos sobre o total de participantes ativos e assistidos, com o intuito de capturar a maturidade de cada plano nos anos analisados, sendo que quanto mais próximo de um for o indicador de maturidade populacional, mais maduro é o plano. Cabe informar que o indicador de maturidade populacional foi concebido neste trabalho para ser utilizado como uma variável explicativa dos modelos. Além de ser utilizado no indicador de maturidade populacional, os dados populacionais

\footnotetext{
${ }^{27}$ Conforme consta da Lei Complementar 108, de 29 de maio de 2001, se a União, os Estados, o Distrito Federal, os Municípios, suas autarquias, fundações, sociedades de economia mista e empresas controladas direta ou indiretamente forem patrocinadoras de um plano de benefícios, o patrocínio de tal plano é definido como público.
} 
também foram utilizados para individualizar o balanceamento atuarial de cada plano de benefícios, em cada período analisado, afim de obter-se a métrica aqui denominada de balanceamento atuarial per capita.

\subsection{Descrição dos dados}

Como os dados atuarias foram o ponto de partida do estudo, parte-se então, nesta seção, para a descrição numérica e estatística das demonstrações atuariais dos anos de 2008 a 2014, período de análise do estudo.

A população ou o número total de planos de benefícios que enviaram demonstrações atuariais ${ }^{28}$ apresentou a seguinte evolução nos anos observados:

Gráfico 1 - Evolução do número de Demonstrações Atuariais

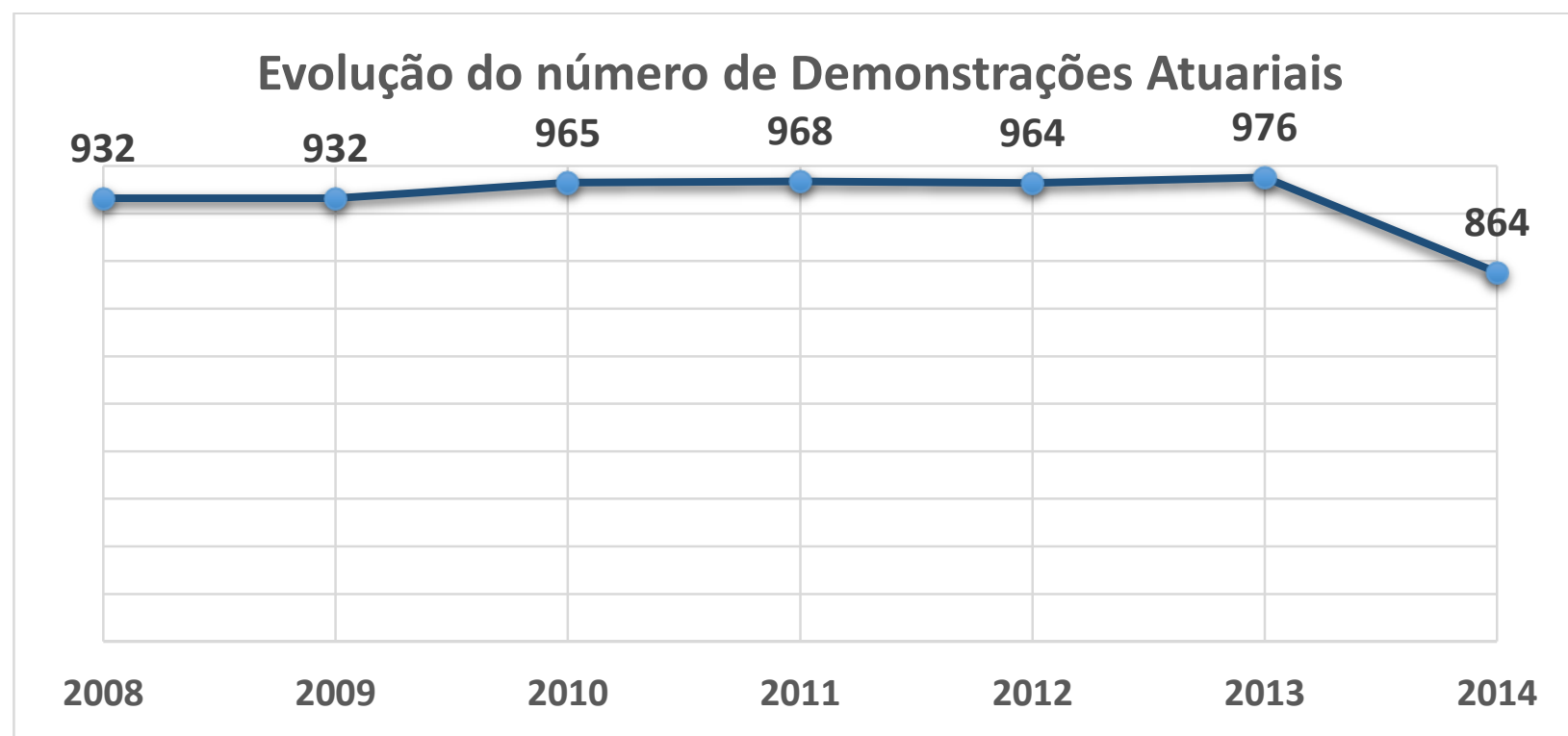

Fonte: Elaboração própria a partir dos dados do BO/DRAA - PREVIC (2008 a 2010) e DAWEB - PREVIC (2011 a 2014).

Entretanto, pelo fato de ter havido cruzamento dos dados atuariais com outras bases, tais como de investimento e cadastrais e com o objetivo de obter dados de painel balanceados, o número de planos de benefícios investigados no período informado ( 7 anos) foi de 605 . Descreveremos as principais estatísticas desses planos a seguir, comparando as médias obtidas para a amostra e para

${ }^{28}$ Os dados aqui informados contêm as Demonstrações Atuariais enviadas até 31/07/2015. 
a população geral. Conforme será visto, o comportamento da grande maioria das variáveis dos modelos indicou uma coerência com aquele verificado para a população.

No que concerne ao universo dos planos analisados na amostra em relação ao total de planos de benefícios que enviaram demonstrações atuariais, a proporção média dos 605 planos sobre o total de planos nos sete anos de observação foi de 64,25\%. Apesar da porcentagem alta, contendo a maioria dos planos da população, não é possível inferir que a amostra reflete adequadamente o comportamento agregado da população. A utilização de dados de painéis balanceados exige que os mesmos planos sejam acompanhados ao longo dos anos, o que por si só já denota um viés de seleção amostral, pois deixou-se de levar em consideração qualquer plano que, por exemplo, tenha sido criado a partir de 2009.

Ainda em relação ao número total de demonstrações atuariais enviadas, cabe apontar que devido a uma mudança na regulamentação, o exercício de 2014 apresentou uma diminuição no número total pelo fato de alguns planos não possuírem mais obrigação legal de enviá-las ao órgão supervisor $^{29}$, além de outros planos terem o prazo máximo para envio de tais demonstrações alterado e $\operatorname{adiado}^{30}$.

Dentro do universo dos 605 planos analisados, o Gráfico 2 apresenta evolução das provisões matemáticas totais e dos patrimônios de cobertura:

Gráfico 2 - Evolução do balanceamento atuarial agregado dos planos de benefícios da amostra (em R $\$$ bilhões)

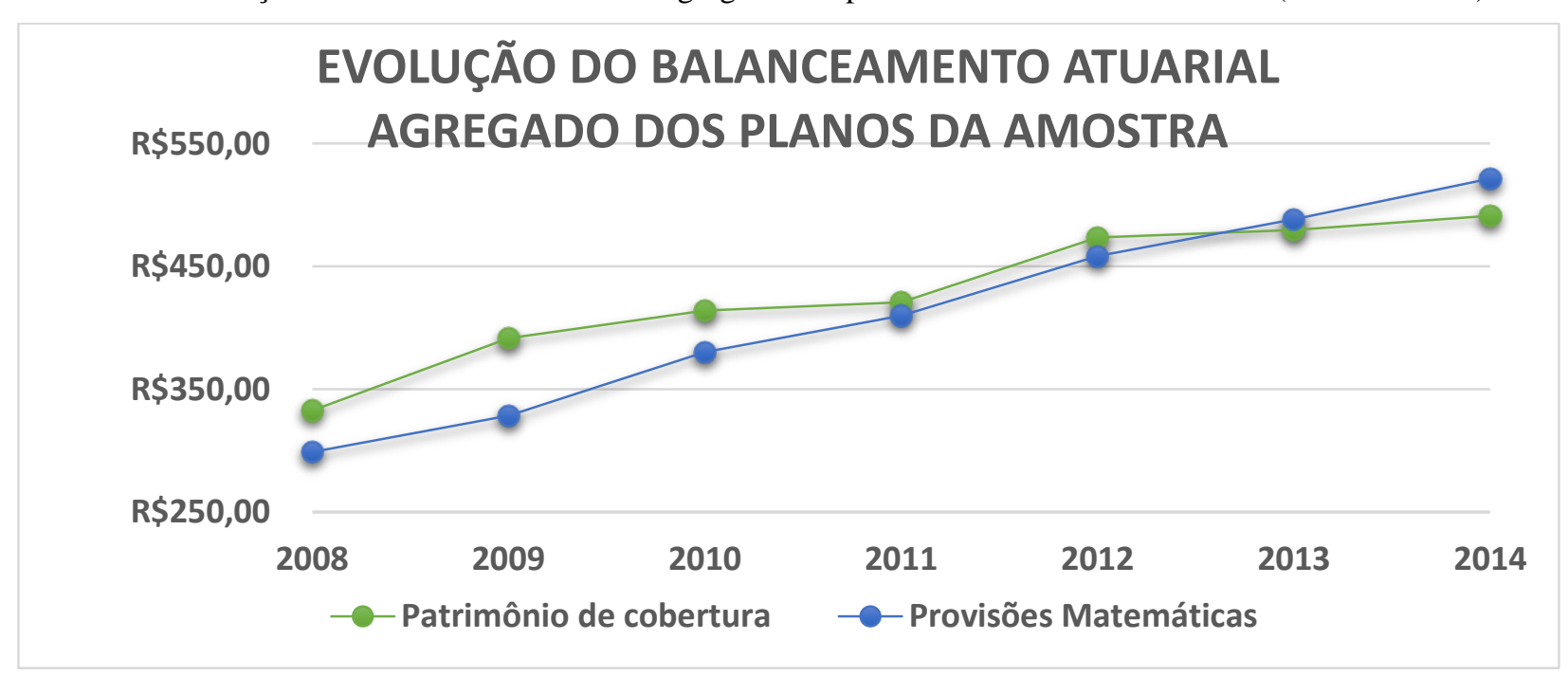

Fonte: Elaboração própria a partir dos dados do BO/DRAA - PREVIC (2008 a 2010) e DAWEB - PREVIC (2011 a 2014).

${ }^{29}$ Ver Instrução Previc no 12, de 13 de outubro de 2014.

${ }^{30}$ Ver Instrução Previc no 20, de 20 de março de 2015 e Instrução Previc no 21, de 23 de março de 2015. 
Se for levado em consideração o universo amostral dos 605 planos analisados nesse estudo, tem-se que somente a partir de 2013 o balanceamento atuarial agregado foi deficitário e nos demais anos observados superavitário. O mesmo movimento foi observado no resultado atuarial na população de planos que enviaram demonstrações atuariais, conforme demonstrado no Gráfico 3, reforçando a consistência agregada em termos de comportamento dos planos da amostra em relação ao da população de planos em análise no período de 2008 a 2014.

Para fins de comparação da evolução do balanceamento atuarial dos planos de benefícios da amostra demonstrados acima com o total de planos, segue o gráfico abaixo:

Gráfico 3 - Evolução do balanceamento atuarial agregado da população dos planos de benefícios (em R\$ bilhões)

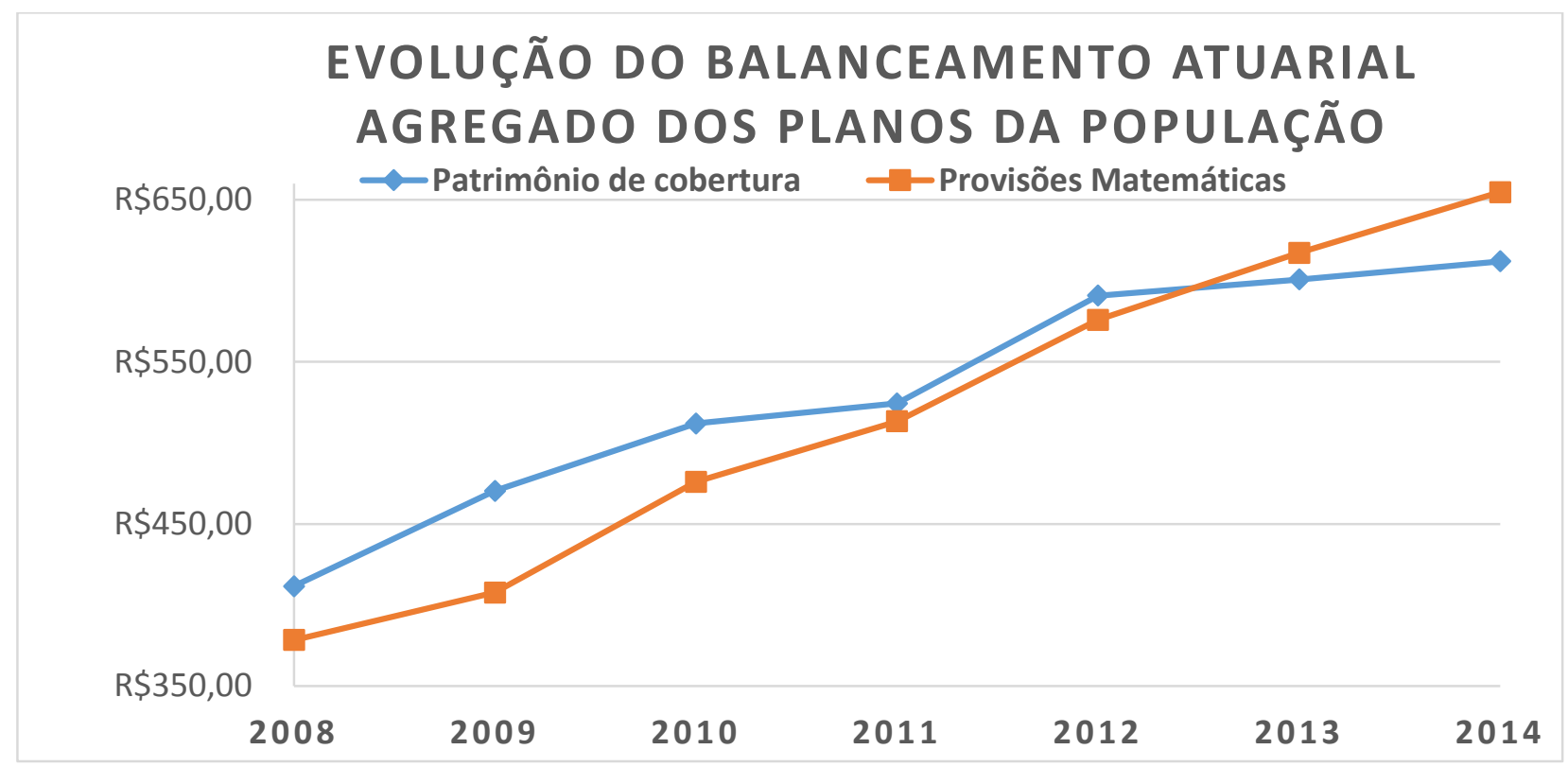

Fonte: Elaboração própria a partir dos dados do BO/DRAA - PREVIC (2008 a 2010) e DAWEB - PREVIC (2011 a 2014).

Já ao observarmos o comportamento do balanceamento atuarial per capita agregado dos planos de benefícios da amostra, em cada um dos anos de observação, temos a seguinte situação: 
Gráfico 4 - Evolução do balanceamento atuarial per capita dos 605 planos de benefícios da amostra (R em milhões)

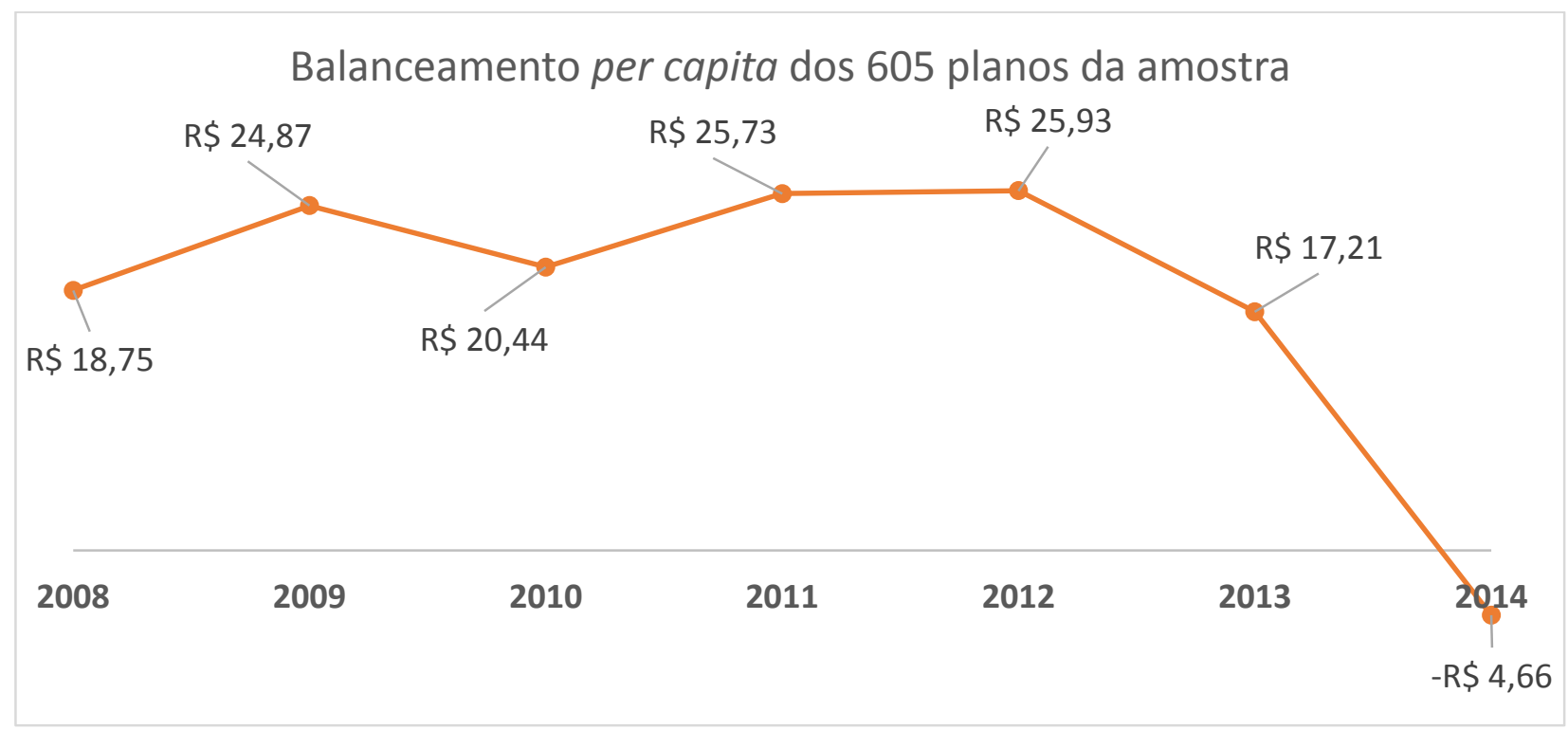

Fonte: Elaboração própria a partir dos dados do BO/DRAA - PREVIC (2008 a 2010), DAWEB - PREVIC (2011 a 2014) e "Tab.2.2 à 2.13 -População por plano - detalhado" - INFGER/PREVIC.

Cabe aqui apontar que o Gráfico 4 reflete de maneira mais fidedigna uma das variáveis observadas nesse estudo, pois o balanceamento atuarial foi calculado per capita para cada um dos 605 planos da amostra em todos os anos de observação e, após tal feito, ano a ano, os valores obtidos para cada plano foram somados. Como houve registro de balanceamentos positivos e negativos, o valor calculado e apresentado no Gráfico 4 reflete a soma dos comportamentos individuais de cada plano de benefícios. Observa-se uma nítida degradação do valor do balanceamento per capita dos planos de benefícios ao longo dos sete anos de observação, de forma mais intensa a partir de 2012 (até 2012 o comportamento parece ser mais estável ou mesmo ascendente), sendo que em 2014 o valor registrado foi negativo e na ordem de aproximadamente $\mathrm{R} \$ 4,6$ milhões para os planos da amostra.

É importante ressaltar que o balanceamento atuarial per capita deve ser interpretado levando em consideração outros fatos relevantes associados às características dos planos de benefícios. O primeiro deles é que grande parte do balanceamento (uma média ao longo dos anos de $94 \%$ ) é em função dos planos $\mathrm{BD}$, pelo fato de serem esses planos os maiores responsáveis pelo acúmulo de provisões matemáticas ao longo dos anos. Além de o balanceamento atuarial per capita refletir de forma mais intensa o comportamento dos 233 planos BD da amostra, é essencial que também se leve em consideração o fato de a grande maioria desses planos já não mais estarem em uma fase de acúmulo, mas sim em uma fase de pagamento de benefícios previdenciários (dispêndio 
de recursos), o que, por si só, já explicaria alguma parte da tendência de decréscimo ao longo dos anos.

Ao comparar o comportamento dos planos da amostra com aquele da população de planos, nota-se um alinhamento na degradação do valor do balanceamento atuarial per capita ao longo dos anos de observação, entretanto a volatilidade observada na população de planos é significativamente maior, assim como o decréscimo nos valores é mais intenso, principalmente a partir de 2011, conforme demonstrado abaixo:

Gráfico 5 - Evolução do balanceamento atuarial per capita da população de planos (em R \$ milhões)

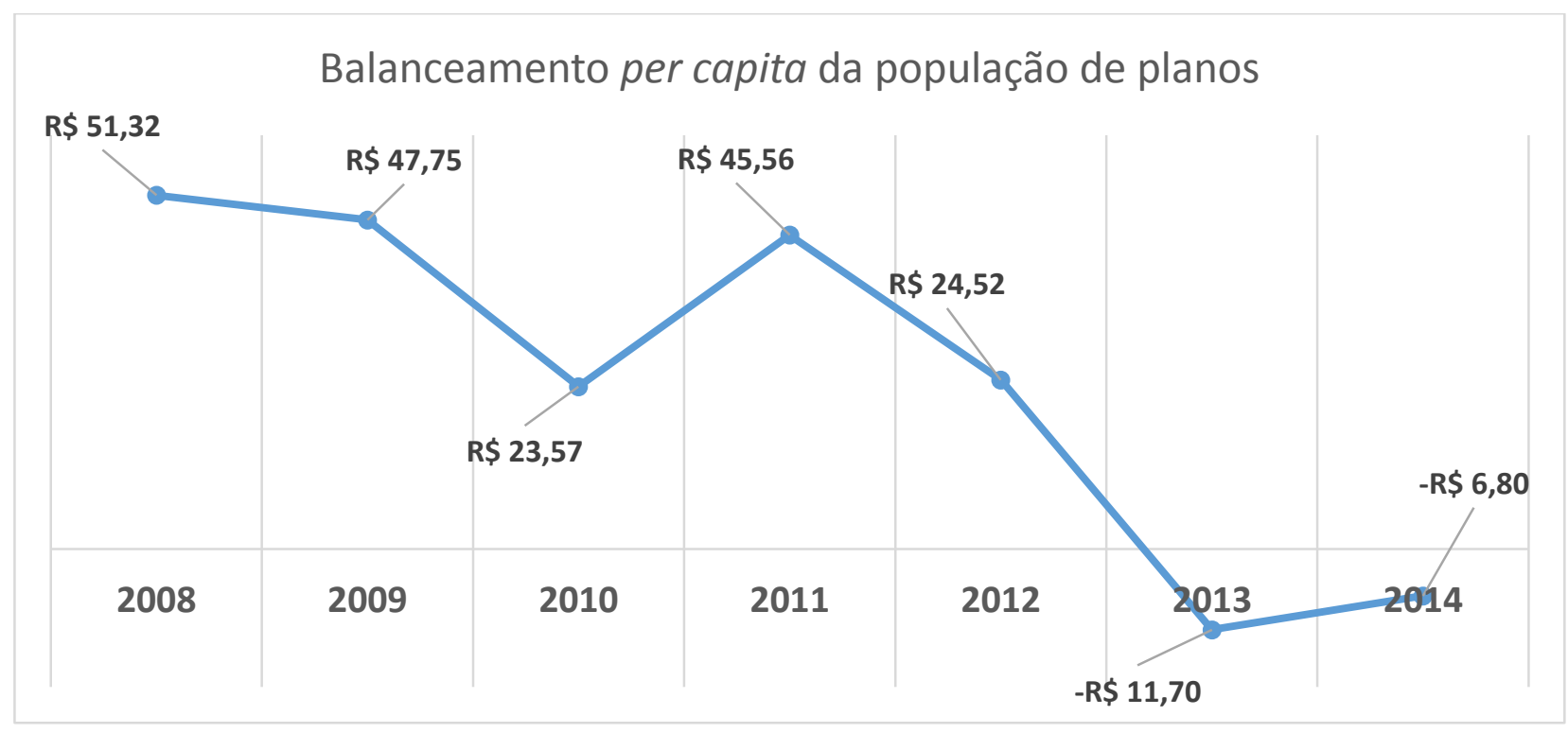

Fonte: Elaboração própria a partir dos dados do BO/DRAA - PREVIC (2008 a 2010), DAWEB - PREVIC (2011 a 2014) e "Tab.2.2 à 2.13 -População por plano - detalhado" - INFGER/PREVIC.

O Gráfico 6 busca obter uma macro visão combinada entre a evolução do balanceamento atuarial per capita dos planos de benefícios da amostra e do número de planos superavitários, deficitários e equilibrados, apresentando o número de planos em cada situação entre 2008 e 2014: 
Gráfico 6 - Evolução da situação atuarial dos planos da amostra

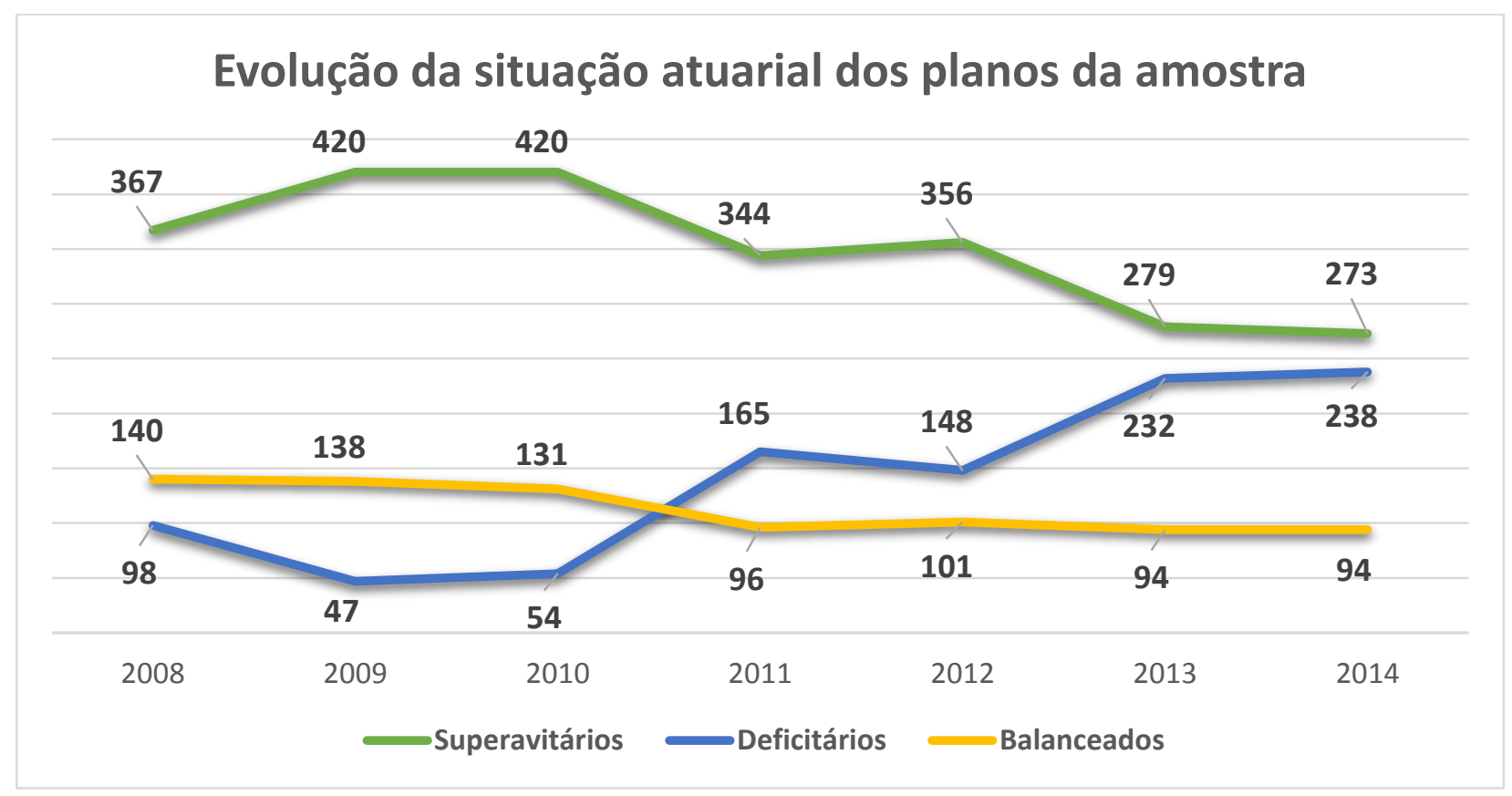

Fonte: Elaboração própria a partir dos dados do BO/DRAA - PREVIC (2008 a 2010) e DAWEB - PREVIC (2011 a 2014).

Percebe-se que as taxas de evolução dos planos deficitários e superavitários, conforme esperado, apresentaram padrões opostos em todos os anos, confirmando a tendência observada nos Gráficos 2 e 4, em que se pode observar uma piora no desempenho dos planos de benefícios ora em análise. $\mathrm{O}$ decréscimo na quantidade de planos superavitários nos 7 anos de observação foi acompanhado pelo crescimento no número de planos deficitários e um decréscimo no número de planos balanceados. Já se observarmos o movimento em relação à situação atuarial da população de planos, observamos o mesmo tipo de comportamento já apontado anteriormente, conforme Gráfico 7 abaixo: 
Gráfico 7 - Evolução da situação atuarial da população de planos

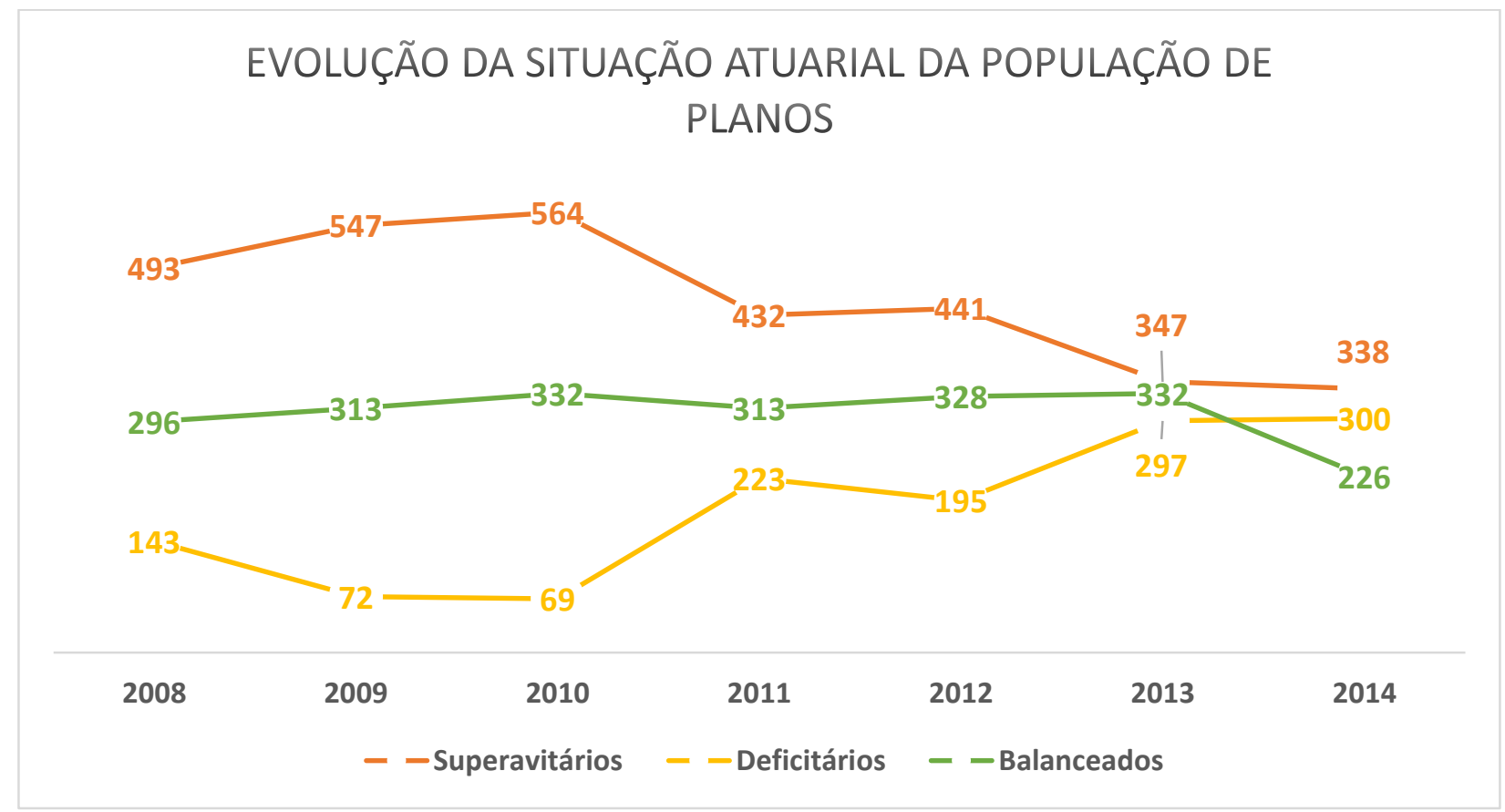

Fonte: Elaboração própria a partir dos dados do BO/DRAA - PREVIC (2008 a 2010) e DAWEB - PREVIC (2011 a 2014).

Quando analisada a distribuição dos planos da amostra entre as modalidades ${ }^{31}$, tem-se:

Gráfico 8 - Distribuição dos planos de benefícios por modalidade

\section{Distribuição dos planos por modalidade}

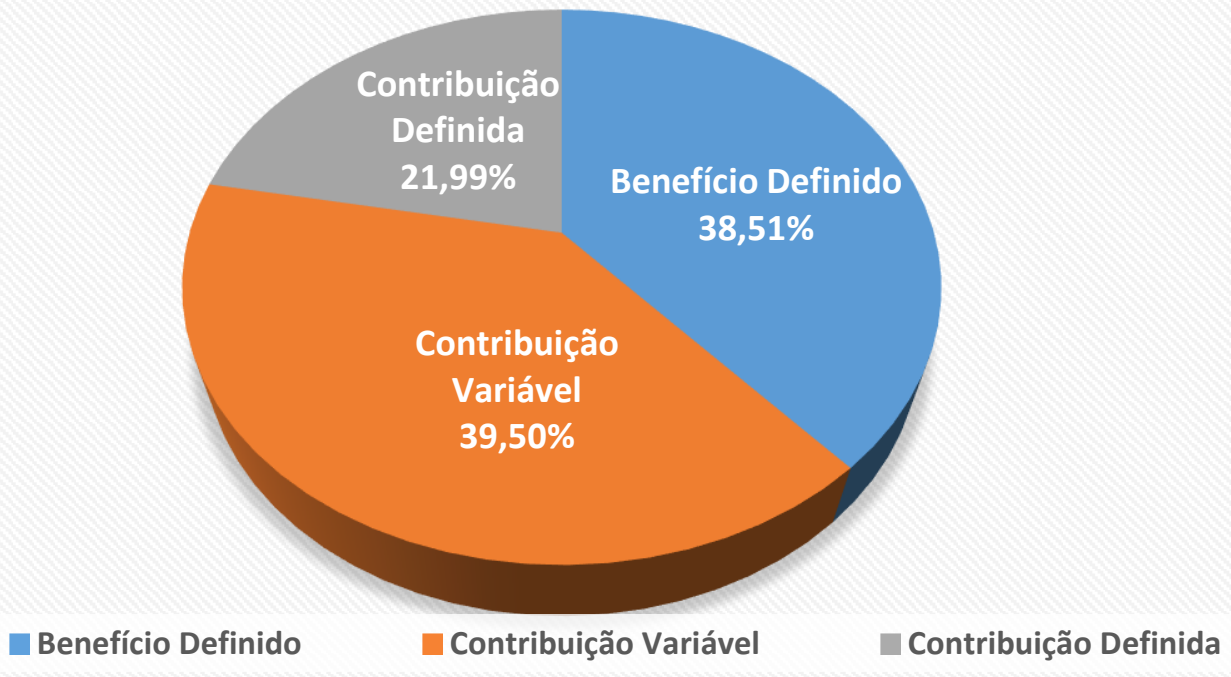

Fonte: Elaboração própria a partir dos dados do BO/DRAA - PREVIC (2008 a 2010) e DAWEB - PREVIC (2011 a 2014).

${ }^{31}$ O número de planos de benefícios por modalidade da amostra foi: 233 planos BD, 239 CV e 133 CD. 
Abaixo, segue a evolução das modalidades da população de planos de benefícios que enviaram demonstração atuarial de 2008 a 2014:

Gráfico 9 - Evolução das modalidades da população de planos de benefícios

\section{EVOLUÇÃO DAS MODALIDADES DA POPULAÇÃO DE PLANOS}

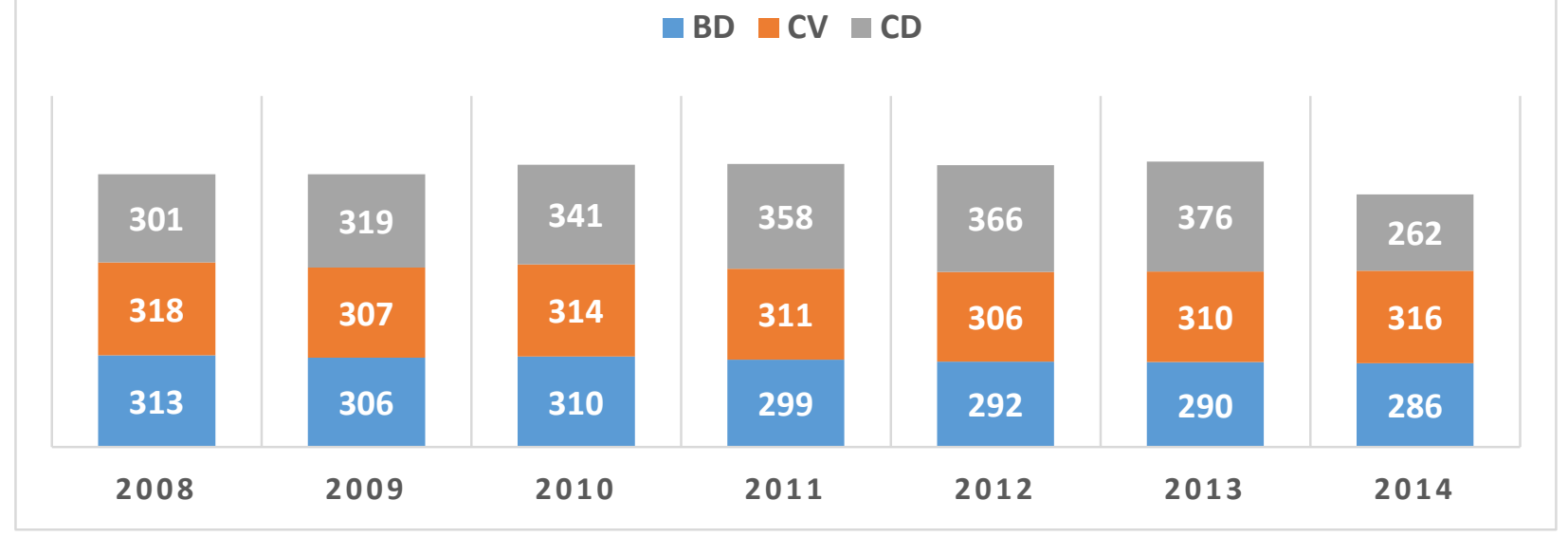

Fonte: Elaboração própria a partir dos dados do BO/DRAA - PREVIC (2008 a 2010) e DAWEB - PREVIC (2011 a 2014).

Em termos de modalidade, a distribuição da amostra em análise e da população de planos de benefícios que enviaram demonstração atuarial diverge um pouco, pois como verificado no Gráfico 9, os planos de modalidade benefício definido (BD) apresentaram uma queda ao longo dos anos, sendo que sua proporção em relação ao total de planos aumentou de 33,58\% em 2008 para $36,95 \%$ em 2014, apesar de o número absoluto ter diminuído ${ }^{32}$. Os planos de modalidade contribuição variável (CV) quase não apresentaram variação ao longo dos anos, já em termos percentuais, notou-se uma evolução em relação ao total de planos pois em 2008 sua representatividade era de 34,12\% e em 2014 registrou-se 40,82\%. Já os planos de benefícios na modalidade contribuição definida (CD), que foram aqueles afetados pela mudança na regulamentação, sendo que parte deles não possuem mais a obrigação de envio das demonstrações atuariais, foram os que apresentaram maior descontinuidade em 2014, pois até então sua representatividade em relação ao total de planos ficava em torno de $36 \%$ e em 2014 caiu para 33,85\%. Dessa forma, a queda observada em 2014 provavelmente não reflete uma redução real do

\footnotetext{
${ }^{32}$ A desobrigação de envio de demonstrações atuariais para os planos CD, introduzida pela Instrução Previc no 12 ,
} de 13 de outubro de 2014 explica a variação na proporção de planos. 
número de planos de modalidade $\mathrm{CD}$, mas apenas um aspecto vinculado à exigência do órgão supervisor.

É importante que se ressalte que a proporção amostral das modalidades de planos permaneceu estática, nos termos do Gráfico 8, por terem sido escolhidos dados de painel para o presente estudo, fato esse que exige o acompanhamento dos mesmos planos de benefícios durante os anos analisados.

Complementando a descrição cadastral dos planos de benefícios no que concerne à legislação aplicável, é importante informar que eles se dividem entre os planos que possuem patrocínio público e por isso estão sob a égide das Leis Complementares $n^{\circ} 108$ e $n^{\circ} 109$, ambas de 29 de maio de 2001 e os planos que possuem patrocínio privado, os quais são regulamentados somente pela Lei Complementar n 109. Em relação ao patrocínio, os planos de benefícios do universo total daqueles planos que enviaram demonstrações atuariais apresentaram a seguinte evolução:

Gráfico 10 - Evolução do patrocínio predominante na população de planos de benefícios

\section{Evolução do patrocínio predominante na população de planos}

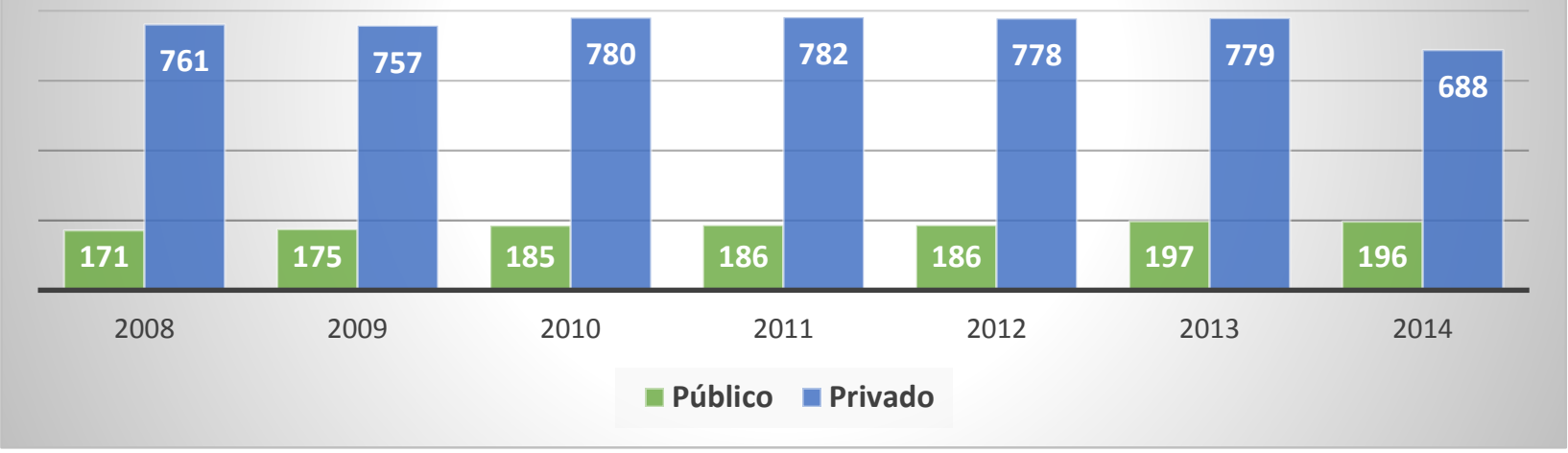

Fonte: Elaboração própria a partir dos dados do BO/DRAA - PREVIC (2008 a 2010) e DAWEB - PREVIC (2011 a 2014).

Quando analisada a amostra de planos de benefícios, verificou-se a seguinte distribuição dos planos por patrocínio predominante (ou legislação aplicável), a qual permaneceu invariável, pelo fato de serem acompanhados os mesmos planos ao longo dos anos: 
Gráfico 11 - Distribuição dos planos de benefícios da amostra por patrocínio predominante

\section{DISTRIBUIÇÃO DOS PLANOS DE BENEFÍCIOS DA AMOSTRA POR PATROCÍNIO PREDOMINANTE}

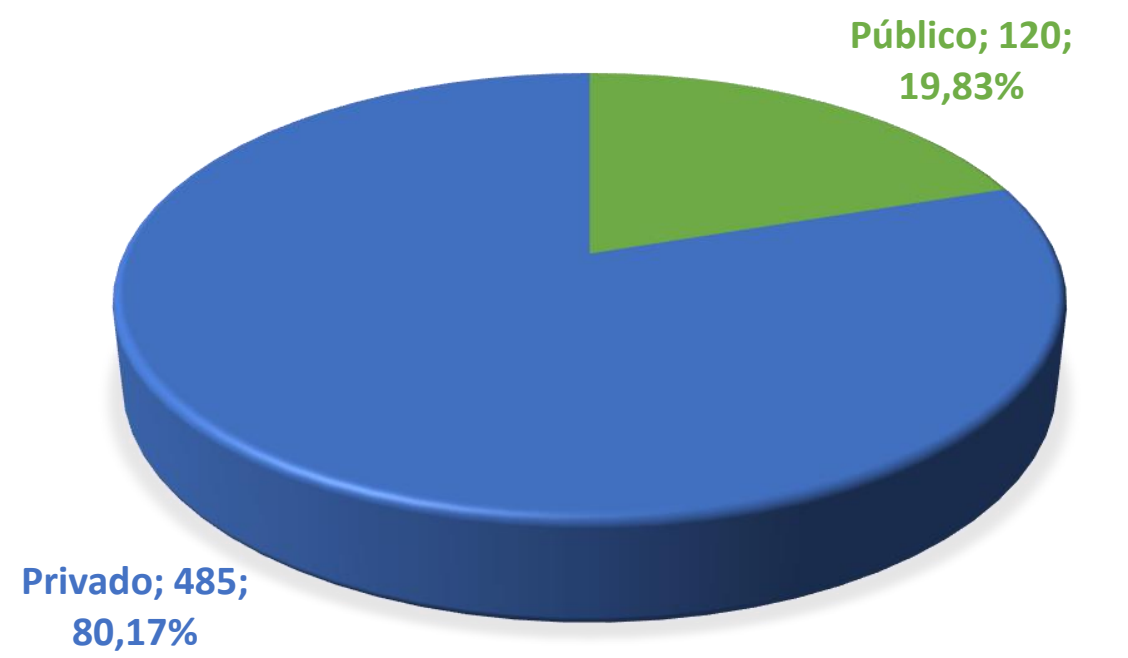

Fonte: Elaboração própria a partir dos dados do BO/DRAA - PREVIC (2008 a 2010) e DAWEB - PREVIC (2011 a 2014).

Pode-se perceber que a proporção de planos com patrocínio público da amostra está bem próxima da média de tais planos da população, pois se considerarmos todos os planos com patrocínio público de 2008 a 2014, verificamos que a média nesses anos foi de 19,59\%, sendo que na amostra tal proporção foi de $19,83 \%$, denotando uma boa reprodução da amostra em relação ao universo de planos de benefícios, ou seja, uma amostra sem viés nesse quesito.

Se levarmos em consideração as proporções de provisões matemáticas e patrimônios de cobertura dos planos de benefícios em função do tipo de patrocínio predominante, verifica-se que apesar do número de planos com patrocínio privado ser bem superior ao número de planos com patrocínio público, esses últimos possuem uma proporção de patrimônio e provisões bem maiores tanto para a população de planos, quanto para os planos da amostra conforme demonstrado nos Gráficos 12 e 13 abaixo: 
Gráfico 12 - Provisões matemáticas e patrimônio de cobertura por patrocínio predominante - população de planos (em R \$ bilhões)

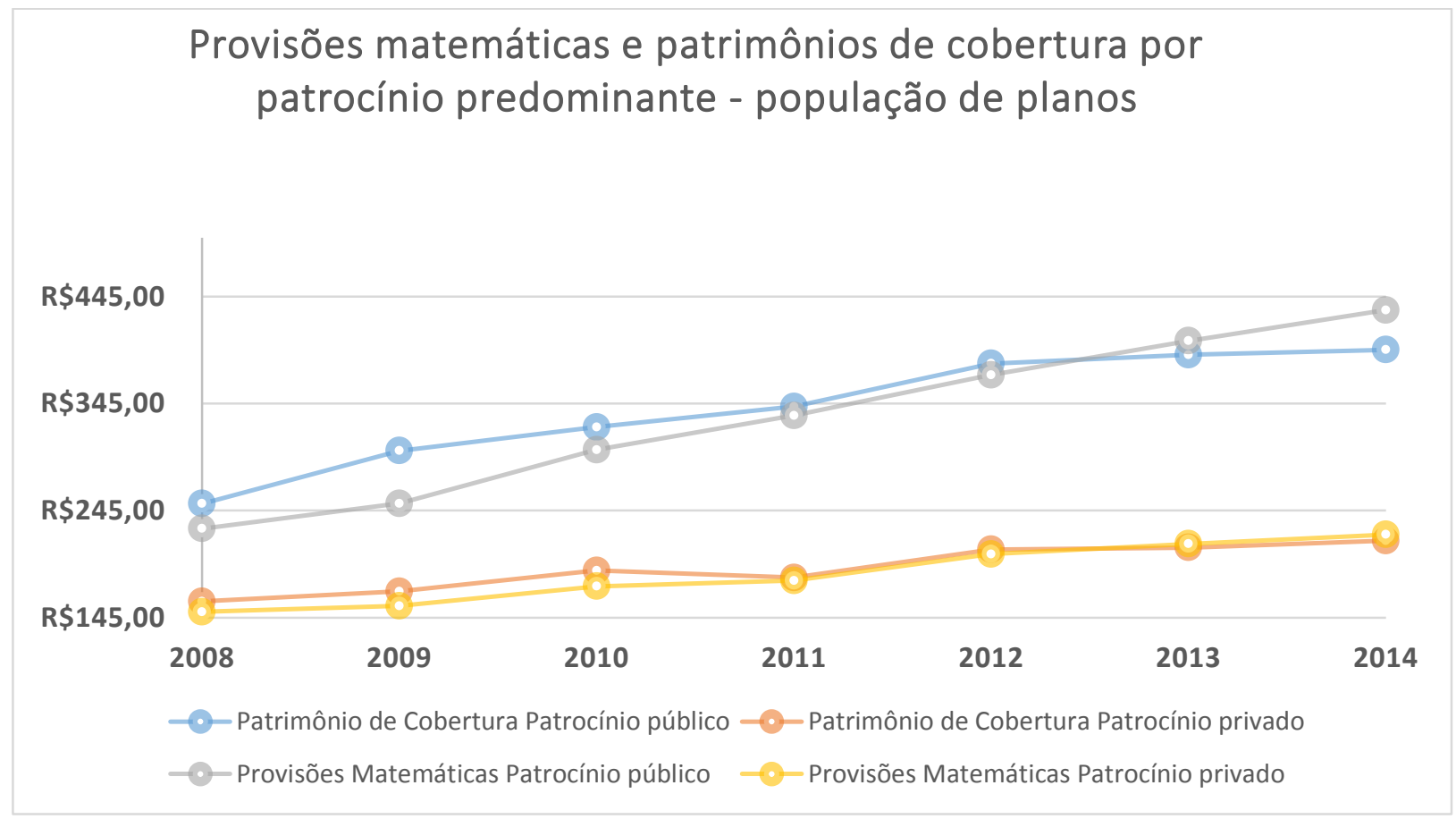

Fonte: Elaboração própria a partir dos dados do BO/DRAA - PREVIC (2008 a 2010) e DAWEB - PREVIC (2011 a 2014).

Gráfico 13 - Provisões matemáticas e patrimônio de cobertura por patrocínio predominante - amostra de planos (em $\mathrm{R}$ bilhões)

\section{PROVISÕES MATEMÁTICAS E PATRIMÔNIOS DE COBERTURA POR PATROCÍNIO PREDOMINANTE - AMOSTRA DE PLANOS}
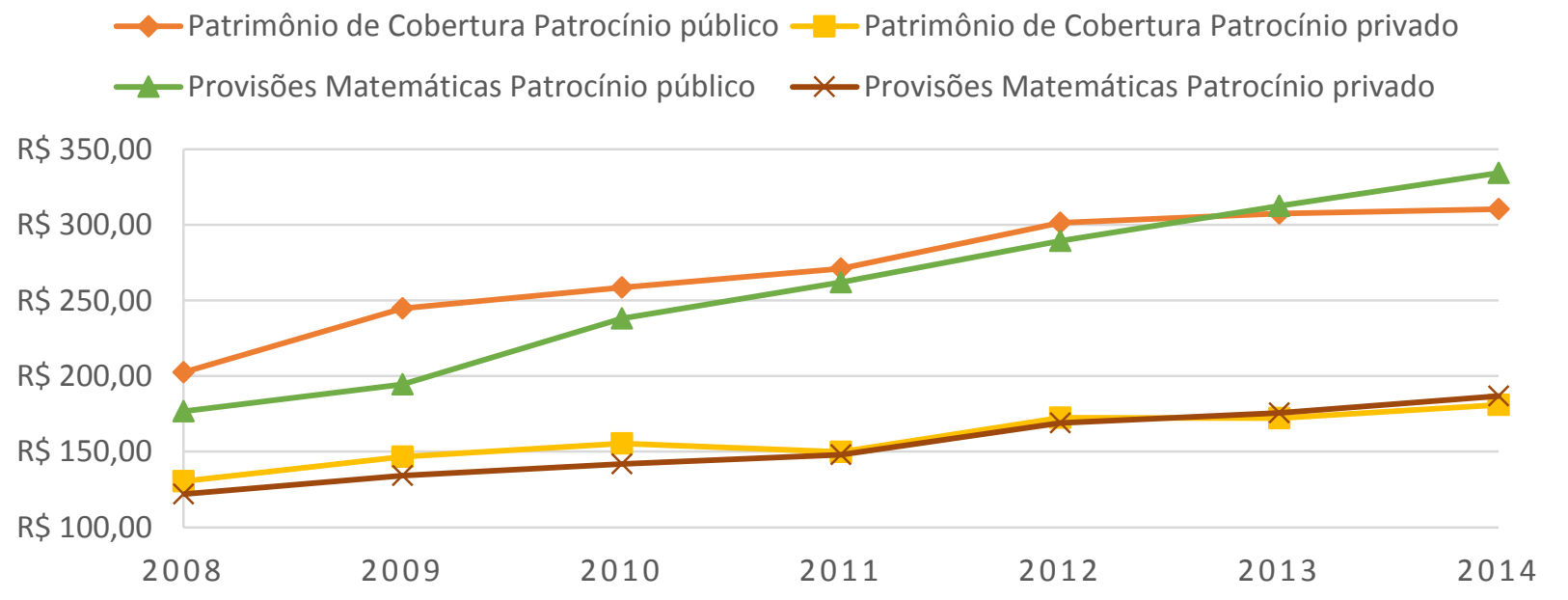
Fonte: Elaboração própria a partir dos dados do BO/DRAA - PREVIC (2008 a 2010) e DAWEB - PREVIC (2011 a 2014).

Analisando todos os planos que enviaram demonstrações atuariais, verificou-se que a média da proporção do patrimônio de cobertura dos planos com patrocínio público ao longo dos anos de 2008 a 2014 ficou em 63,94\% do patrimônio cobertura total dos planos, muito próxima da mesma média encontrada para a proporção das provisões matemáticas, que foi de $63,76 \%$ para o mesmo período. As proporções encontradas para os 605 planos da amostra ficaram muito próximas das da população, sendo que a média encontrada para o patrimônio de cobertura foi de $63,01 \%$ e para as provisões matemáticas de $62,32 \%$. Observou-se que os planos com patrocínio privado mostraramse mais balanceados que os planos com patrocínio público, tanto na população quanto na amostra, tal constatação fica mais evidente no exercício de 2009, quando o balanceamento agregado para os dois tipos de planos foi positivo, mas numa proporção bem maior para os planos com patrocínio público e em 2014, quando o balanceamento agregado foi negativo, mas da mesma forma os com patrocínio público apresentaram resultado atuarial negativo muito mais acentuado.

Se observarmos o comportamento dos planos da amostra de acordo com o patrocínio predominante, temos:

Gráfico 14 - Balanceamento atuarial per capita por patrocínio predominante da amostra (em R $\$$ milhões)

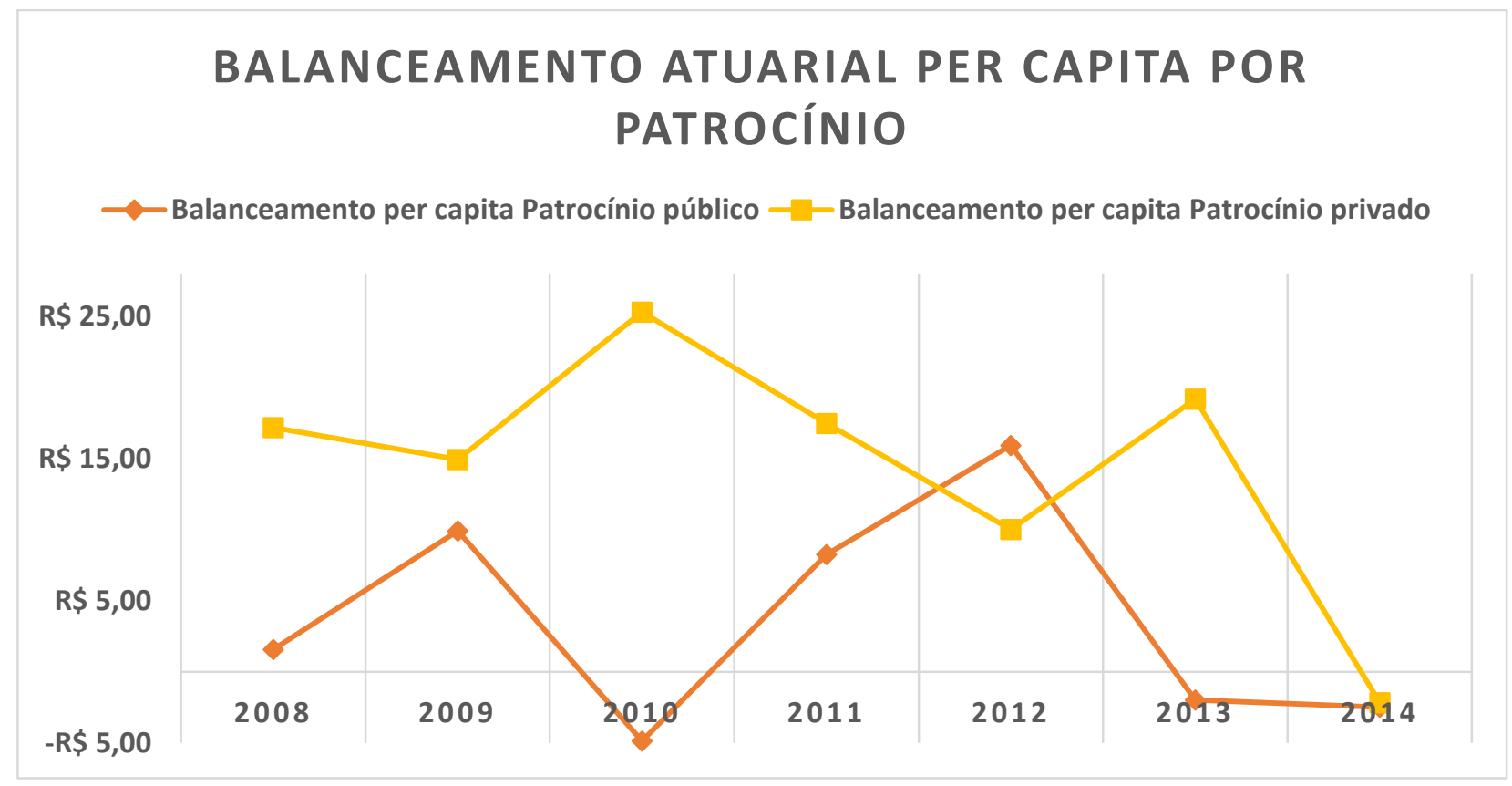

Fonte: Elaboração própria a partir dos dados do BO/DRAA - PREVIC (2008 a 2010) e DAWEB - PREVIC (2011 a 2014). 
Cabe aqui observar a tendência discrepante entre o balanceamento atuarial per capita dos planos com patrocínios público e privado, principalmente até 2012. Enquanto os planos com patrocínio público melhoraram seu balanceamento, os privados o pioraram. Já de 2012 a 2013, os balanceamentos per capita apresentaram comportamentos apartados, com os públicos negativos e os privados positivos para em 2014 se encontrarem no lado negativo.

Adicionalmente, ao compararmos o número total de participantes de todos os planos, tanto na condição de ativos, a qual corresponde à fase de acumulação de recursos, quanto na condição de assistidos, que representam as pessoas em gozo de benefícios com o número de participantes abrangidos na amostra analisada, temos a seguinte evolução:

Gráfico 15 - Evolução do número total de participantes: população versus amostra

\section{Evolução do total de participantes: população versus amostra}

3.500 .000

3.000 .000

2.500 .000

2.000 .000

1.500 .000

1.000 .000

500.000

0

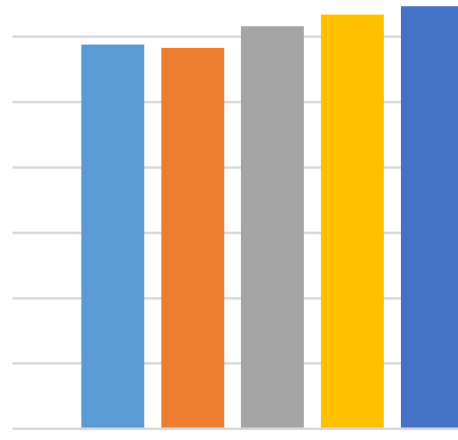

População de participantes

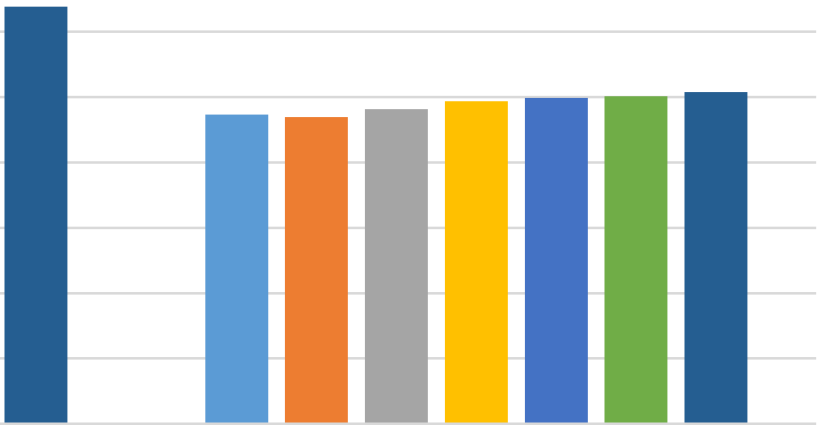

Amostra de participantes

口 $2008 \quad 2009 \square 2010 \square 2011 \square 2012 \quad 2013 \square 2014$

Fonte: Elaboração própria a partir dos dados da "Tab.2.2 à 2.13 -População por plano - detalhado" INFGER/PREVIC.

Conforme análise do Gráfico 15, percebe-se que em termos de variação ano a ano a amostra se mostrou divergente da população apenas em 2014, pois nesse período houve um decréscimo da população total abrangida pelos planos de benefícios que enviaram as demonstrações atuariais pelas razões já mencionadas, ao passo que a amostra apresentou um crescimento suave ao longo dos sete anos de observação. Pela própria forma de construirmos a amostra, que exigia que o plano fornecesse informações para todos os anos, não seria mesmo esperado que houvesse a queda no número de participantes observada para a população total. 
Já ao verificarmos a representatividade da população de participantes da amostra, observase uma média bem elevada, de cerca de $78,49 \%$ da população de participantes do sistema de previdência complementar reproduzida no estudo. Isso significa que a mostra contém planos relativamente maiores, o que era esperado, pois planos maiores tendem a ser melhor estruturados e, por isso, mais capazes de produzir relatórios e enviar informações ao órgão supervisor com maior regularidade.

Buscando averiguar a maturidade dos planos de benefícios, foi concebido o indicador de maturidade populacional da seguinte forma para cada ano de observação:

- Indicador de maturidade populacional $t_{t}=\frac{\text { Número de assistidos } \text { a }_{t}}{\text { Número total de } \text { participantes }_{t}}$

$\mathrm{O}$ indicador de maturidade populacional buscou capturar o efeito do dispêndio financeiro característico na fase de pagamento dos benefícios, pois quanto mais próximo de 100\%, mais maduro um plano se encontra, devendo, em tese, já ter acumulado recursos suficientes para a consecução de sua principal função, qual seja, o pagamento de benefícios. Esse indicador também buscou refletir a idade média da população de cada plano, visto que tais dados não existem para todo o período de análise ao qual este estudo se propôs.

A seguir apresentamos a maturidade dos planos de benefícios analisados em comparação com o universo de planos que enviaram as demonstrações atuariais, em cada ano de observação e por modalidade, afim de ter uma visão macro do quão próximo da fase de pagamento os planos se encontram.

Os planos na modalidade benefício definido (BD) apresentaram uma maturidade populacional ao longo dos anos de 2008 a 2014, conforme explicitado no Gráfico 16 abaixo: 
Gráfico 16 - Maturidade dos planos de benefício definido: população versus amostra

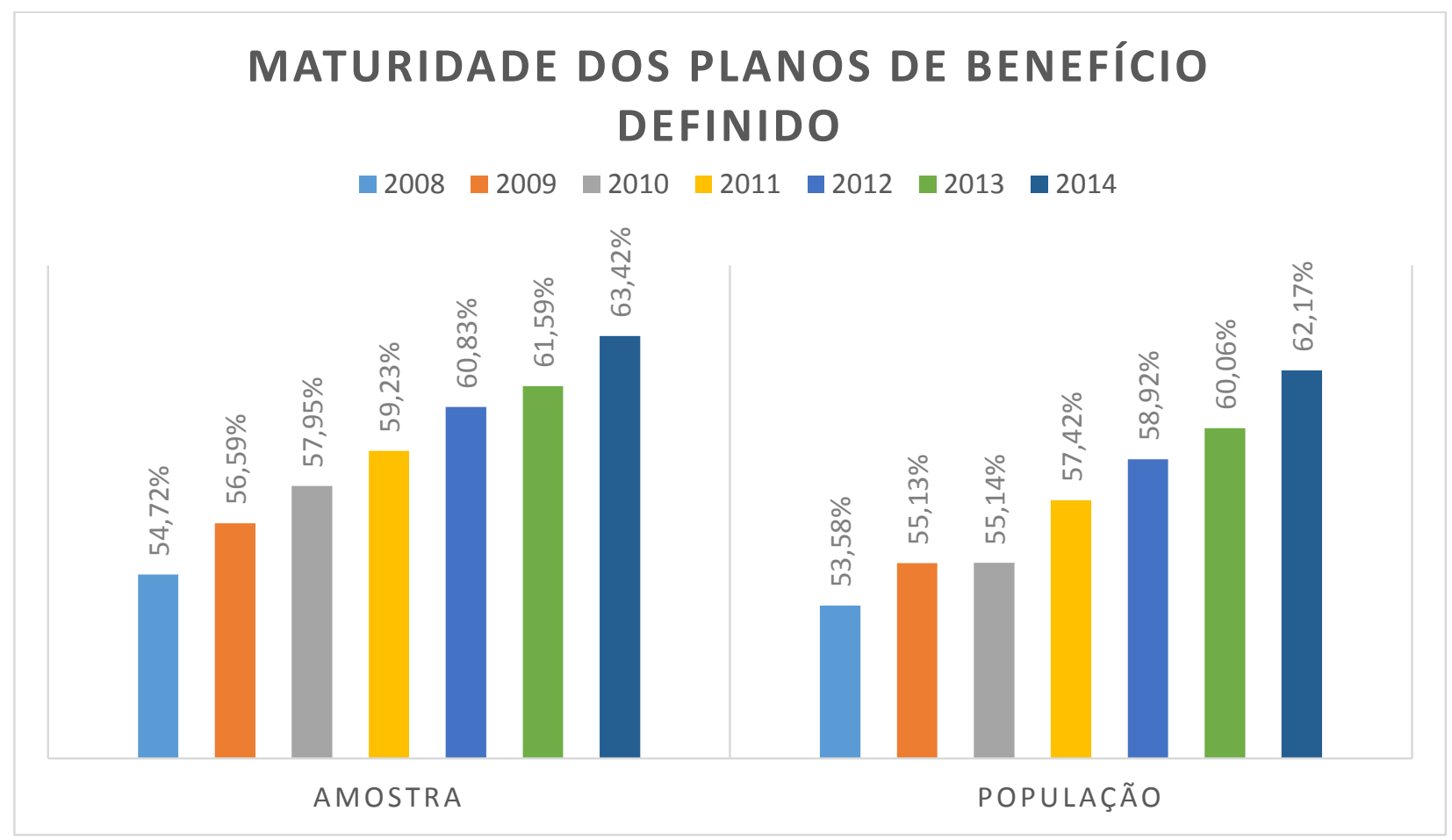

Fonte: Elaboração própria a partir dos dados da "Tab.2.2 à 2.13 -População por plano - detalhado" INFGER/PREVIC.

Percebe-se que tanto a população de planos quanto a amostra analisada no estudo vêm apresentando uma evolução na maturidade verificada pelo cálculo do indicador de maturidade populacional agregado para todos os planos BD em cada ano de observação. A amostra de planos de benefícios analisada apresentou um comportamento de crescimento suave e consistente durante os anos observados. No entanto, verificou-se que o patamar de maturidade da amostra foi sempre um pouco acima do patamar do universo dos planos.

Os planos de contribuição variável apresentaram uma maturidade bem menos elevada que os planos de benefício definido, conforme demonstra o Gráfico 17 abaixo: 
Gráfico 17 - Maturidade dos planos de contribuição variável: população versus amostra

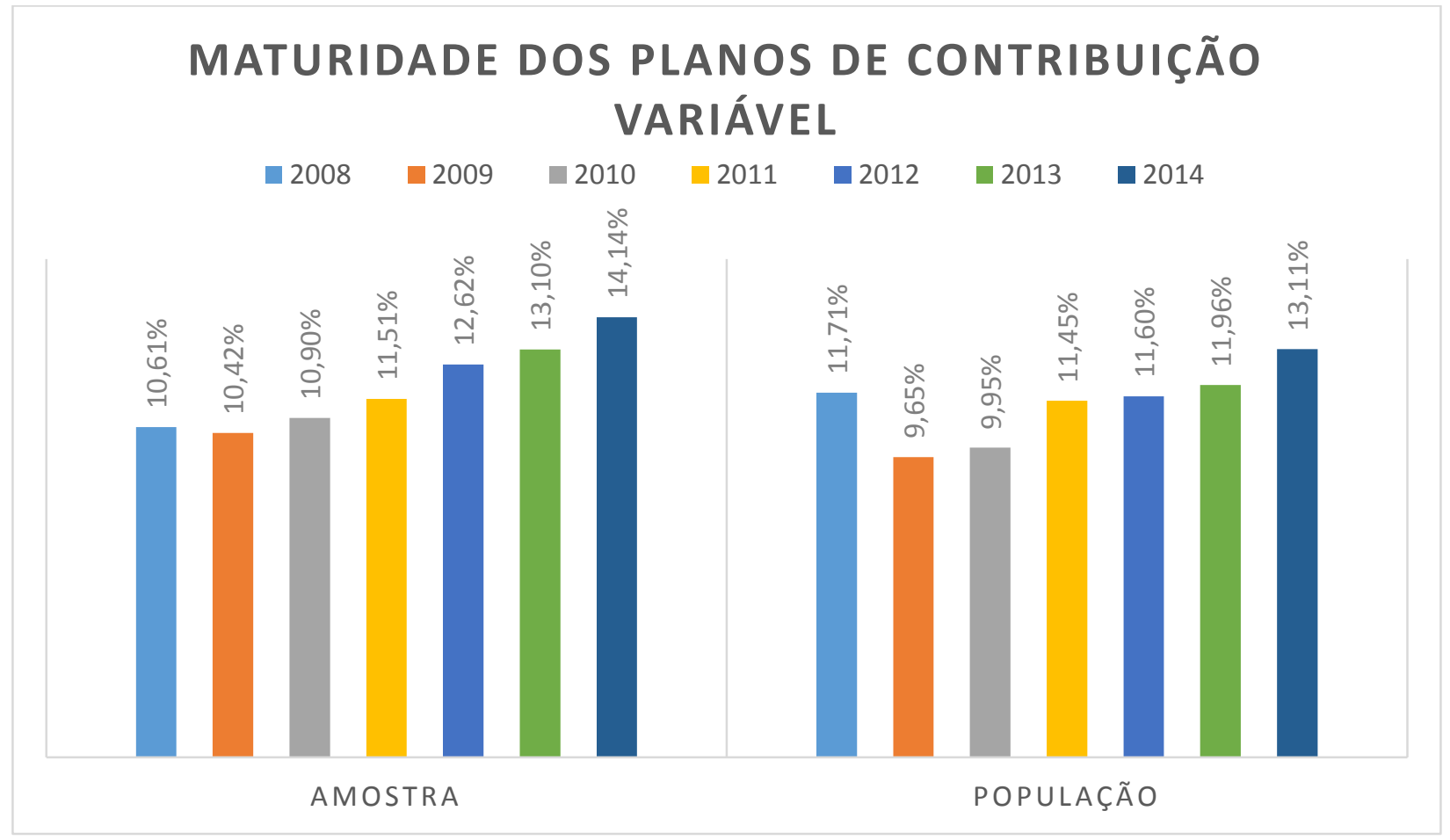

Fonte: Elaboração própria a partir dos dados da "Tab.2.2 à 2.13 -População por plano - detalhado" INFGER/PREVIC.

O comportamento do universo total de planos e da amostra analisada foi similar, apenas variando no patamar de maturidade, pois os planos da amostra apresentaram em todos os períodos uma maturidade populacional um pouco mais elevada que todos os planos que enviaram demonstrações atuariais. Da mesma forma que os planos $\mathrm{BD}$, os planos $\mathrm{CV}$ apresentaram comportamento mais suavizado, apresentando um decréscimo na sua maturidade populacional de 2008 a 2009 e, a partir de então, verificou-se amadurecimento populacional até 2014.

Os planos na modalidade contribuição definida apresentaram um patamar de maturidade populacional menor que os planos BD e CV, conforme esperado, por serem planos mais recentes. Segue a evolução do indicador médio no período de análise: 
18 - Maturidade dos planos de contribuição definida: população versus amostra

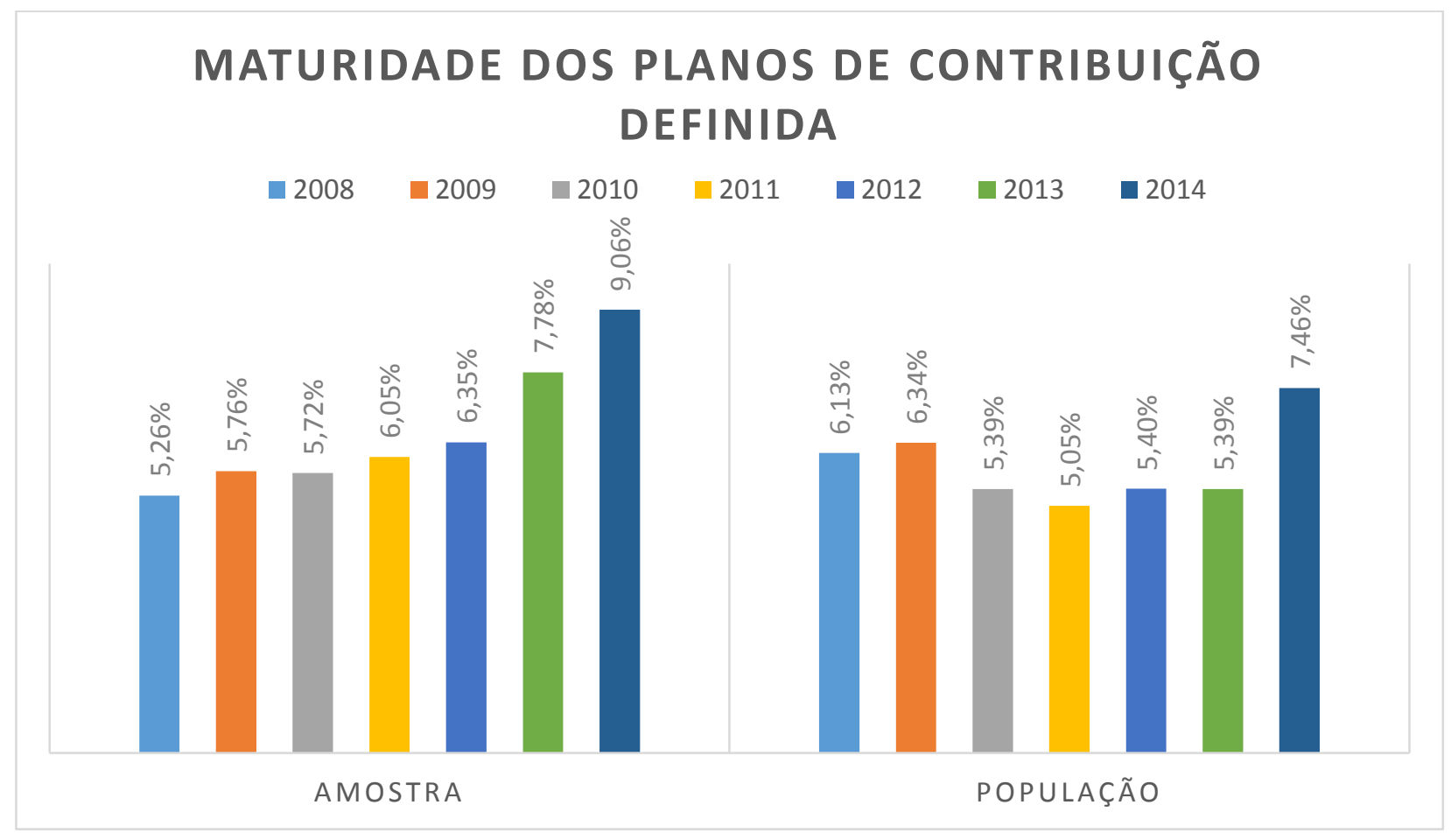

Fonte: Elaboração própria a partir dos dados da "Tab.2.2 à 2.13 -População por plano - detalhado" INFGER/PREVIC.

Os planos CD foram a modalidade de planos que apresentaram maior discrepância entre o comportamento do universo de planos que enviaram demonstrações atuariais e a amostra analisada. Apesar dessa discrepância não ser muito relevante, cabe apontar que, de 2010 para 2011, a população de planos apresentou um pequeno decréscimo no amadurecimento populacional, enquanto a amostra de planos apresentou evolução na maturidade. O outro período em que se verificou uma divergência de comportamentos foi de 2012 para 2013, a amostra de planos apresentou amadurecimento populacional enquanto o universo dos planos CD apresentou uma redução na maturidade.

Aqui cabem alguns comentários sobre o comportamento observado dos planos de benefícios de 2008 a 2014: no caso dos planos BD, por serem planos que, no passado, mostraram fortes desequilíbrios atuariais, a maioria deles não admite mais novos participantes, sendo natural, portanto, o envelhecimento de seus participantes. Além disso, a própria amostra viesa o aumento da maturidade, pois não contém planos novos (todos os planos tinham de existir já em 2008). Tal fato talvez explique o viés para cima da amostra em relação à população, mas não o aumento do grau de maturidade, já que ele aumentou também para a população em geral. 
Há questões tecnológicas que podem ajudar a entender o viés para cima da amostra em relação à população. Elas fazem com que não seja necessário repor na mesma proporção cada trabalhador que se aposenta.

Em termo de contextualização política, aponte-se que o mandato da presidente Dilma foi de desaceleração do crescimento econômico, com crescimento pequeno no número de postos de trabalho. Nesse quadro de desaceleração, as firmas tendem a dispensar primeiro trabalhadores mais jovens, ou a reduzir as contratações, sem repor integralmente as saídas via aposentadoria ou morte.

A próxima variável a ser analisada é o perfil de risco dos planos de benefícios, tanto da população de planos, quanto da amostra. Lembre-se que o indicador de perfil de risco mede a proporção dos ativos mais arriscados sobre o total de ativos do plano em cada período de tempo analisado, conforme já descrito na seção denominada "Base de dados". Quanto mais próximo de um for, maior é a proporção de ativos de pouco risco que um plano possui em sua carteira em determinado período.

Com o intuito de obter uma visão geral do indicador de perfil de risco dos planos de benefícios, foi calculada a média aritmética dos indicadores calculados para cada plano, por ano de observação e observou-se o seguinte comportamento para o universo de planos que enviaram demonstrações atuariais e para os planos da amostra:

Gráfico 19 - Evolução do perfil de risco médio: amostra versus da população de planos

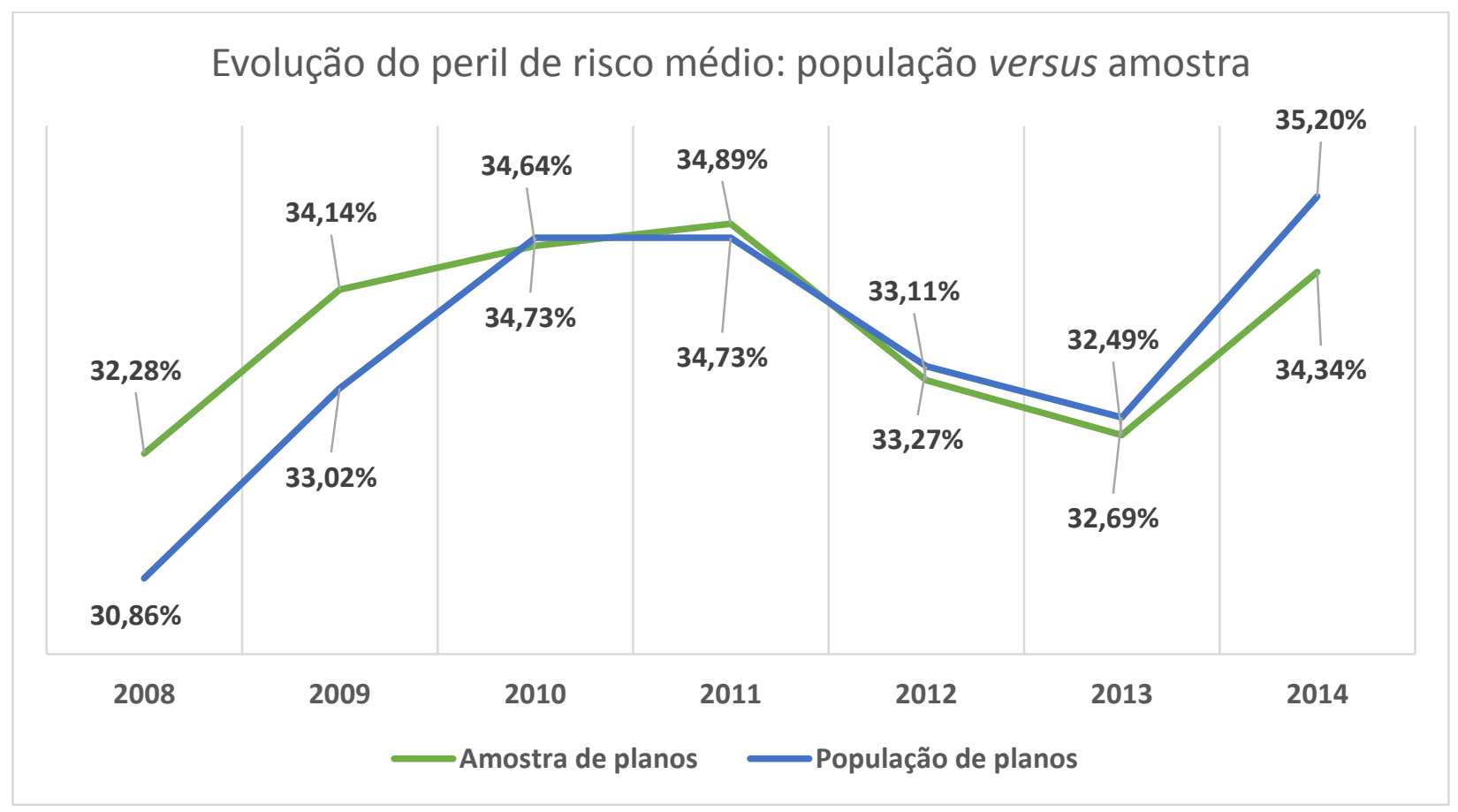


Fonte: Elaboração própria a partir dos dados dos Demonstrativos de Investimentos (DI/PREVIC) do quarto trimestre de 2008 ao quarto trimestre de 2014.

Assim como a grande maioria das variáveis já descritas nessa seção, verificou-se que o comportamento da população de planos e da amostra mostraram-se com tendências parecidas, apresentando crescimento de alocação média em títulos privados e ações de 2008 a 2011, depois um período de queda até 2013 e um novo crescimento em 2014. Em uma análise preliminar e heurística, a alocação em ativos mais arriscados não parece seguir a teoria do ciclo de vida de investimento e poupança, pois denota-se um crescimento de investimento nesses ativos ao longo dos anos de observação, mesmo com a evolução da maturidade populacional dos planos.

A fim de finalizar a descrição dos dados utilizados neste estudo, parte-se agora para a taxa real anual de juros, ou taxa atuarial, utilizada para descontar os fluxos futuros de benefícios. Essa taxa é de suma importância para o cálculo da parcela dos valores atuais de benefícios futuros (VABF) das provisões matemáticas, por ser a hipótese que mais fortemente influencia tal cálculo. Para a descrição das taxas reais anuais de juros utilizadas pelos planos de benefícios, apresentarse-ão as taxas reais anuais de juros médias, conforme informadas nas demonstrações atuariais. Para os planos na modalidade benefício definido (BD) e contribuição variável (CV), temos:

Gráfico 20 - Evolução da taxa real anual de juros média dos planos BD e CV

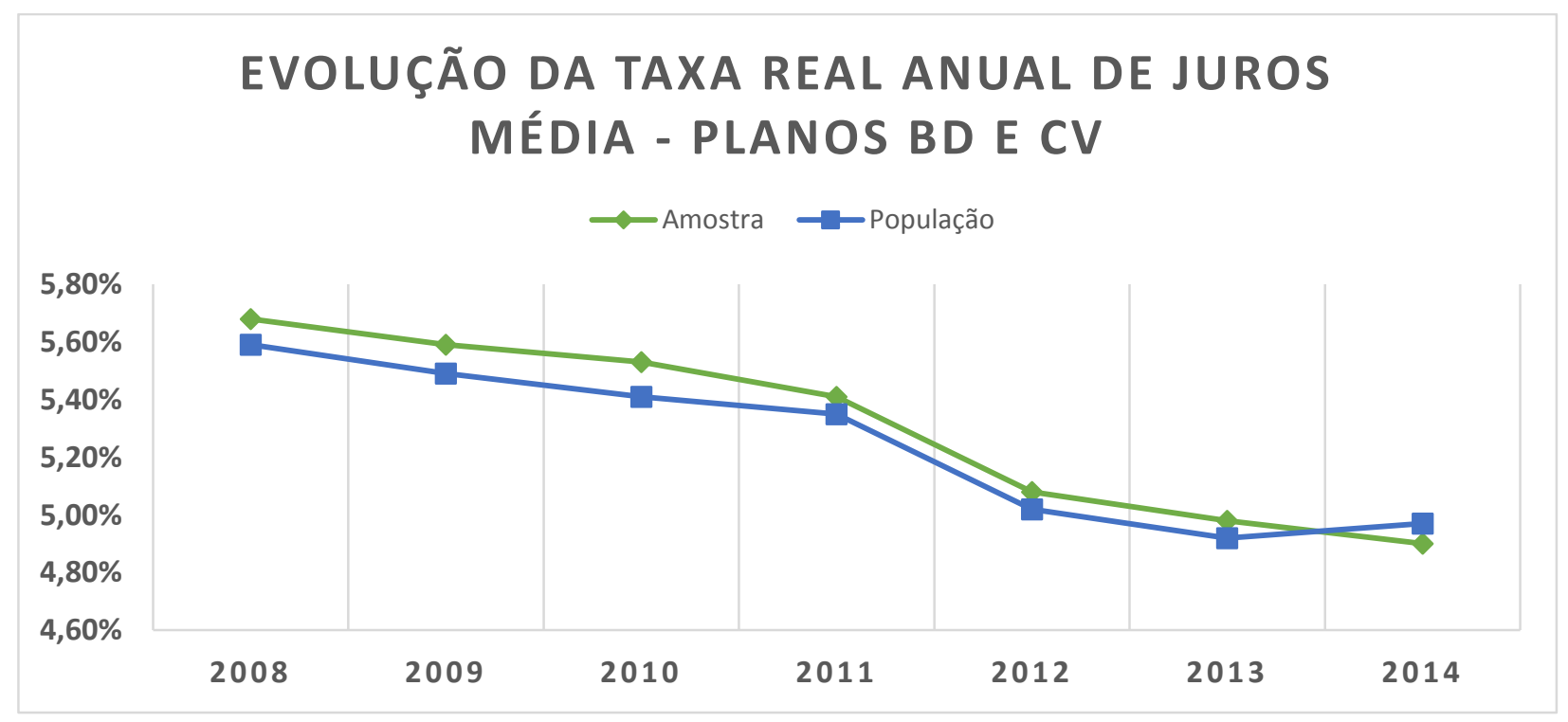

Fonte: Elaboração própria a partir dos dados do BO/DRAA - PREVIC (2008 a 2010) e DAWEB - PREVIC (2011 a 2014).

Percebe-se uma tendência de queda na taxa real anual de juros utilizada pelos planos de benefícios tanto no universo quanto na amostra, sendo que o comportamento dos planos da 
amostra, como verificado na maioria dos dados utilizados, apresenta patamar um pouco mais elevado de taxa real anual de juros. Cabe ainda apontar que os planos BD e CV foram agrupados por possuírem benefícios programados atuarialmente calculados, os quais levam em consideração riscos como de longevidade, de morte, de invalidez, além de outros e, portanto, apenas faz sentido falar em desconto de fluxos de benefícios quando há projeção de benefícios que envolvem cálculos atuariais.

Já os planos CD, via de regra, não precisam ter premissa relativa à taxa de juros, pois ela não influencia no cálculo das suas provisões matemáticas. Afinal, esses planos funcionam como fundos de investimento tradicionais, em que o participante recebe aquilo que investiu junto com as contribuições do patrocinar e a rentabilidade, não havendo necessidade de ser feito qualquer cálculo atuarial de expectativa de sobrevida, probabilidade de incapacitação para o trabalho, etc.

Entretanto, há planos na modalidade de contribuição definida que informam a hipótese de taxa real anual de juros. Para esses planos o comportamento da população de planos que enviaram demonstrações atuariais e a amostra analisada se deu da seguinte forma:

Gráfico 21 - Evolução da taxa real anual de juros média dos planos CD

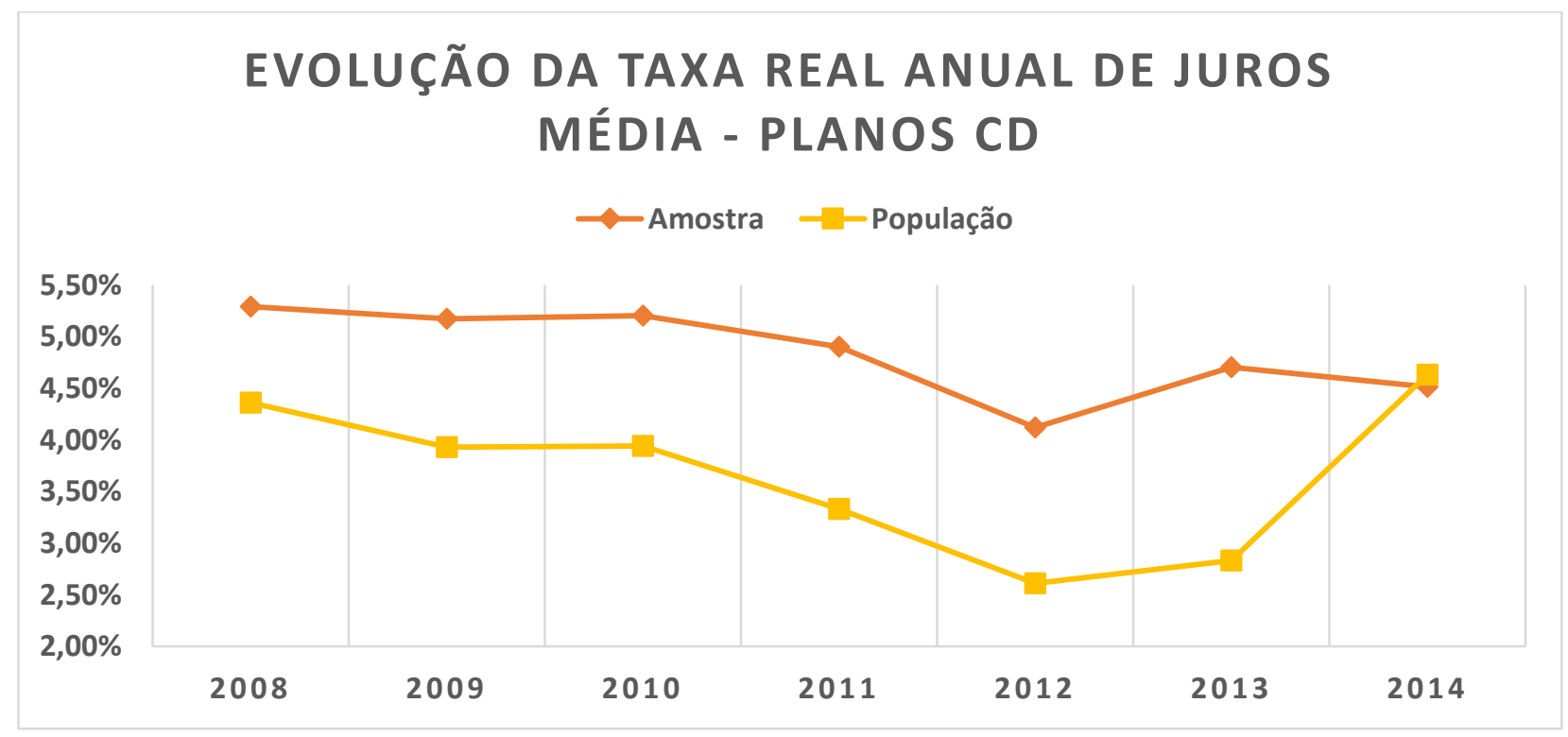

Fonte: Elaboração própria a partir dos dados do BO/DRAA - PREVIC (2008 a 2010) e DAWEB - PREVIC (2011 a 2013).

Para os planos na modalidade contribuição definida (CD) percebeu-se uma maior volatilidade no período de análise do estudo e um patamar de taxa média menor que do que aquele observado para os planos BD e CV. 
Importante destacar que no ano de 2014 foi registrada uma pequena alta na média das taxas reais de juros utilizadas nos planos de benefícios para a população de planos, a qual pode ser explicada em parte pela mudança da regra para sua definição. Até novembro de 2014, havia apenas a imposição legal de um limite máximo para adoção da taxa real anual de juros como taxa de desconto. Historicamente esse limite era de $6 \%$ ao ano, e, a partir de 2012, acompanhando o movimento observado para a taxa SELIC, passaria a sofrer decréscimos de $0,25 \%$ ao ano até atingir 4,5\% ao ano em 2018. Cabe aqui apontar que o balanceamento atuarial também foi afetado por essa mudança, pois obrigou ${ }^{33}$ os planos de benefícios a diminuir sua taxa de desconto, aumentando o valor atual das provisões matemáticas.

Entretanto a definição da regra de precificação de passivo no que concerne à taxa real anual de juros sofreu uma modificação estrutural com a Resolução do Conselho Nacional de Previdência Complementar (CNPC) $\mathrm{n}^{\circ}$ 15, de 19 de novembro de 2014. A definição legal passou a atrelar explicitamente a taxa de juros utilizada como taxa de desconto para apuração do valor presente dos fluxos de benefícios e contribuições de um plano ao valor esperado da rentabilidade futura de seus investimentos. Além de refletir o valor esperado da rentabilidade futura, a taxa real anual de juros parâmetro para cada plano de benefícios deve estar vinculada à duração do passivo dos fluxos de pagamento de benefícios, mais especificamente ao ponto da Estrutura a Termo de Taxa de Juros ${ }^{34}$ (ETTJ) mais próximo à duração do passivo do respectivo plano de benefícios.

\subsection{Método de análise}

O objetivo principal foi explicar o comportamento das seguintes variáveis:

- o balanceamento atuarial per capita dos planos de benefícios; e

- o perfil de risco dos planos.

O balanceamento, conforme explicado no Capítulo 4, é a diferença entre as provisões matemáticas e o patrimônio de cobertura dos planos de benefícios em um determinado período.

\footnotetext{
${ }^{33}$ Para aqueles planos de benefícios que comprovassem rentabilidade esperada maior que a taxa máxima de desconto definida, havia a possibilidade de requerer autorização do órgão supervisor nos termos da Instrução Previc no 1/2013.

${ }^{34}$ Estruturas a Termo de Taxa de Juros diárias baseadas nos títulos públicos federais indexados ao Índice de Preço ao Consumidor Amplo (IPCA).
} 
Como a base de dados utilizada contém o número de participantes em cada período, optou-se por individualizar o balanceamento, com a finalidade de suavizar a única variável financeira utilizada nos modelos com as outras variáveis qualitativas e quantitativas. Já para o perfil de investimento, foi utilizado o indicador de perfil de risco dos planos, o qual consiste na proporção de títulos privados e ações sobre o total de ativos investidos pelo plano em um certo período. Tanto para o balanceamento quanto para o perfil de risco foram utilizados dados de painel.

Dados de painel ou dados longitudinais consistem em observações de uma mesma unidade, no caso específico essa unidade se traduz em cada plano de benefícios, em períodos de tempo (2008 a 2013) diferentes (Kennedy, 2008).

A análise de dados longitudinais ou dados de painel representa a união de regressões lineares e análise de séries temporais (Frees, 2003). Diferentemente dos dados de regressão linear de corte transversal, com dados longitudinais há a oportunidade de observar os indivíduos com o passar do tempo e, com a observação de vários indivíduos ao longo de alguns anos, é possível estudar a dinâmica que os rege, além dos aspectos de cortes transversais do(s) objeto(s) de estudo.

Hsiao (2003) e Klevmarken (1989) apontam vários benefícios advindos do uso de dados de painel, incluindo:

i. Controle da heterogeneidade individual - dados de painel sugerem que os indivíduos são heterogêneos, enquanto dados de séries temporais e de cortes transversais, ao não controlar tal heterogeneidade, correm o risco de gerarem resultados enviesados.

ii. Dados longitudinais apresentam mais dados informativos, mais variabilidade, menos colinearidade entre as variáveis, mais graus de liberdade e mais eficiência. A dimensão de dados de corte transversal adiciona variabilidade e dados mais informativos, o que tende a produzir estimativas de parâmetros mais confiáveis.

iii. Dados de painel são necessários para estimar relações intertemporais, modelos de ciclo de vida e modelos intergeracionais. Na verdade, dados de painel conseguem relacionar experiências individuais e comportamentais em um período específico com comportamentos e experiências em outro ponto do tempo.

iv. Dados de painel são melhores para identificar e medir efeitos que simplesmente não são detectáveis em cortes transversais puros ou séries temporais puras. Para efeitos individuais que não variam no período de tempo observado, os estimadores fazem 
inferências baseadas em comparações dos indivíduos com eles mesmos ao longo do tempo em vez de comparações entre os diferentes indivíduos.

v. Os modelos de dados de painel permitem que sejam construídos e testados modelos comportamentais mais complexos que os modelados com cortes transversais puros ou séries temporais puras, pois tais modelos impõem menos restrições em modelos com defasagem do que séries temporais.

No entanto, Batalgi (2005) aponta algumas limitações do uso de dados de painel:

i. Problemas de coleta de dados, tais como não resposta e impossibilidade de cobertura da totalidade da população de interesse, no caso de respostas de questionários.

ii. Distorções na medida dos erros que podem surgir de respostas incertas devido a perguntas não claras, erros de memória ou distorção de respostas, todas registradas em pesquisas.

iii. Perda de informações de um ano para outro ou saída indesejada de dados, devido, por exemplo a descontinuidade da unidade de observação como morte, no caso de pesquisas com pessoas ou indisponibilidade de informações no caso de estudos de observação. Essa perda de informações é conhecida como taxa de atrito em dados longitudinais.

As duas variáveis objeto variam ao longo do tempo para cada plano de benefícios, entretanto outras variáveis inseridas no modelo, tais como modalidade do plano e patrocínio predominante, são características que tendem a ser fixas ao longo do tempo.

Quando há observações para todas as unidades durante todo o período de observação, os dados de painel são classificados como balanceados. Já para os casos em que não há informação para todas as unidades em todos os períodos observados, os dados são classificados como desbalanceados. Tradicionalmente, a grande maioria da literatura econométrica depositou seu foco no caso de dados balanceados e, neste estudo, o foco também será em um conjunto de dados balanceados, visto que todas as variáveis constantes dos modelos utilizados são observadas para todos os 605 planos de benefícios ao longo dos 7 anos de observação. Conforme a Seção 4.2 mostrou, a amostra balanceada tem características muito semelhantes às da população.

As regressões balanceadas estimadas de 2008 a 2014 para os dados de painel utilizados foram:

i. $\quad$ Bal. per cap. . $_{i t}=\beta_{0}+\beta_{1} C V_{i}+\beta_{2} C D_{i}+\beta_{3}$ Patr $_{\cdot i}+\beta_{4}$ Ind.risco $_{i t}+\beta_{5}$ Ind.mat.pop ${ }_{i t}+\beta_{6}$ Tx. juros $_{i t}+\alpha_{i}+\varepsilon_{i t}$;

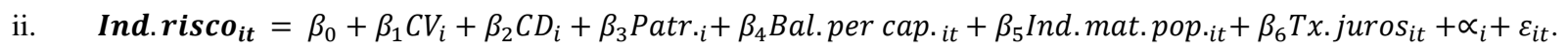


Onde:

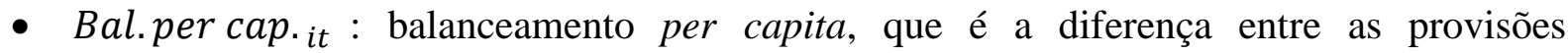
matemáticas e o patrimônio de cobertura do plano de benefícios em cada ano observado, dividido pelo número total de participantes do plano no mesmo período de observação;

- Ind.risco ${ }_{i t}$ : indicador de perfil de risco, o qual traduz a proporção dos ativos mais arriscados em relação ao total de ativos da carteira de investimentos de cada plano de benefícios em cada ano observado;

- $\beta_{0}$ : intercepto estimado;

- $C V_{i}$ : indica os planos de benefícios de modalidade contribuição variável, trata-se de informação qualitativa descrita através de uma variável binária ou dummy, constante ao longo dos anos observados, com 1 para os planos CV e 0 para os demais;

- $C D_{i}$ : indica os planos de benefícios de modalidade contribuição definida, trata-se de informação qualitativa descrita através de uma variável binária ou dummy, constante ao longo dos anos observados, com 1 para os planos CD e 0 para os demais. Observe-se que dadas essa dummies, o caso base será a modalidade BD.

- Patr. $_{. i}$ : patrocínio do plano de benefícios, variável qualitativa constante ao longo dos anos observados, descrita como uma variável binária ou dummy e que pode ser público (valor 0) ou privado (valor 1);

- Ind.mat.pop.it: o indicador de maturidade populacional foi calculado anualmente para cada plano de benefícios, é a quantidade de assistidos ou número de pessoas em fase de recebimento de benefícios, sobre o total de participantes do plano;

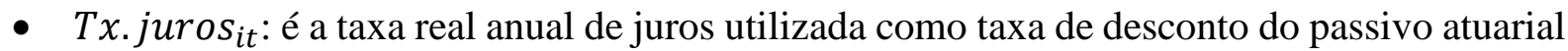
de cada plano, ao longo de cada ano de observação;

- $\propto_{i}$ : componente individual não observado que varia de plano para plano, também chamado de variável latente;

- $\varepsilon_{i t}:$ resíduos ou erros idiossincráticos.

Uma das motivações para o uso de dados de painel é a resolução do problema das variáveis omitidas, a escolha do modelo para estimar as regressões propostas assim como com modelos de dados de painel de uma forma geral, começa com a discussão da natureza do(s) efeito(s) não 
observado(s). Para escolher o modelo mais apropriado a fim de estimar as regressões apresentadas, o principal fator a ser levado em consideração é a variável latente $\propto_{i}$. De acordo com Wooldridge (2002), essa variável não observada pode ser constante ou não no tempo e antes de adentrar nos métodos de estimação de dados de painel é de suma importância que se leve em conta a natureza dos efeitos não observados e algumas características das variáveis explicativas observadas para que as hipóteses dos modelos sejam validadas.

O ponto nevrálgico que define o tipo de modelo que melhor se adequa aos dados analisados reside em saber se o componente individual não observado $\left(\propto_{i}\right)$ será tratado como um efeito aleatório ou como um efeito fixo. No caso de ser tratado como um efeito aleatório, o componente individual não observado será estimado como uma variável aleatória, já se for tratado como um efeito fixo, será um parâmetro a ser estimado. A hipótese chave a ser feita em relação ao componente não observado é o fato de ele ser ou não correlacionado com as outras variáveis explicativas observadas. Segundo Greene (2003) a diferença essencial entre efeitos fixos e aleatórios está no fato de o efeito individual não observado $\left(\propto_{i}\right)$ incorporar elementos que são correlacionados com os regressores do modelo e não com o fato de tais efeitos serem estocásticos ou não.

Conforme veremos no Capítulo 5, o teste de Hausman mostrou que o modelo de efeitos fixos se adéqua melhor à base de dados.

\subsubsection{O balanceamento atuarial per capita e seus efeitos não observados}

No caso do balanceamento atuarial per capita dos planos de benefícios, é possível entendêlo como uma métrica de solvência e seu resultado tende a refletir a precificação tanto das provisões matemáticas (precificação do passivo), quanto do patrimônio de cobertura de um plano (precificação do ativo) em um determinado período. Segundo Gazzoni (2014), três são os principais fatores que influenciam na precificação do passivo atuarial de um plano:

- O regime financeiro;

- O método de financiamento; e

- As hipóteses atuariais.

Segundo Ferreira e Mano (2009), existem três tipos de regimes financeiros que são adotados no custeio da previdência aberta e fechada: 
- repartição simples: neste regime as contribuições são suficientes para cobrir somente os benefícios em cada exercício;

- repartição de capitais de cobertura: as contribuições são suficientes para garantir o valor presente dos benefícios que são gerados no exercício, havendo a constituição da provisão matemática de benefícios concedidos, neste regime, as contribuições serão revistas a cada ano, não ocorrendo formação da provisão matemática de benefícios a conceder;

- capitalização: as contribuições são suficientes para cobrir os benefícios iniciados no exercício, como também os que serão gerados no futuro. Neste caso, a provisão matemática de benefícios concedidos e a provisão matemática de benefícios a conceder serão totalmente constituídas antecipadamente à sua concessão. Ao regime financeiro de capitalização, agrega-se, necessariamente, um método atuarial ou método de custeio, que irá definir a forma de financiamento dos benefícios.

Como o regime financeiro e o método de financiamento se referem aos benefícios de um plano e não ao plano de benefícios como um todo, que é a unidade de observação desse estudo, tais tópicos não serão aqui detalhados ${ }^{35}$. Entretanto as hipóteses atuariais, que constituem a base da mensuração e precificação do passivo atuarial e, principalmente, a sua aderência e adequação à massa de participantes de cada plano de benefícios podem ser vistas como as variáveis omitidas do modelo, ou o(s) efeito(s) não observado(s) dos dados de painel ora em pauta.

Dentre todas as hipóteses atuariais utilizadas na avaliação de um plano de benefícios, a com maior impacto é a taxa real anual de juros, pois é por meio dela que os fluxos de contribuições e benefícios futuros são trazidos a valor presente, fazendo com que sua adequação e aderência influencie sobremaneira a precificação das provisões matemáticas e, por consequência o balanceamento atuarial de um plano. A hipótese de taxa real anual de juros pôde ser observada para os planos ao longo dos anos de 2008 a 2014, no entanto, sua adequação e aderência não.

Da mesma forma que não foi possível a observação da aderência da hipótese atuarial de taxa real anual de juros, que é a mais impactante na precificação das obrigações atuariais de um plano, a aderência e adequação de outras hipóteses atuariais relevantes, tais como, tábuas biométricas, indexadores e projeções de crescimento real dos salários, também não puderam ser observadas. As hipóteses atuariais são as premissas técnicas que influenciam no cálculo do passivo

\footnotetext{
35 Para um maior detalhamento dos tipos de regimes financeiros e métodos de financiamento ver "Fundamentals of Pension Funding", Charles L. Trowbridge, 1952.
} 
atuarial, representando um conjunto de estimativas de natureza demográfica, biométrica, econômica e financeira, e, caso não reflitam a realidade do desempenho de um plano de benefícios ao longo dos anos com um certo grau de segurança, tornam-se uma ameaça para a solvência do plano.

Um plano de benefícios pode ser percebido como solvente sob duas perspectivas, segundo Benjamin (1977): se ele for capaz de cobrir todas suas obrigações em uma situação de liquidação imediata (break-up basis ou solvência estática) e se for capaz de pagar todas as suas dívidas à medida que amadurecem (going-concern basis ou solvência dinâmica). Se levarmos em consideração os aspectos estático e dinâmico da solvência, e de modo especial a precificação das provisões matemáticas dos planos de benefícios (precificação do passivo), podemos perceber mais fortemente ainda a aderência e adequação das hipóteses atuariais como os efeitos não observados ou a variáveis omitidas que ajudariam a explicar o balanceamento atuarial per capita dos planos de benefícios nos anos observados.

A principal norma que aborda a adequação e aderência das hipóteses atuariais de um plano benefícios é a Resolução CGPC n ${ }^{\circ} 18$, de 28 de março de $2006^{36}$, que no item 1 de seu Anexo explicita:

1. As hipóteses biométricas, demográficas, econômicas e financeiras devem estar adequadas às características da massa de participantes e assistidos e do plano de benefícios de caráter previdenciário.

(...)

Lembremo-nos da equação proposta para explicar o balanceamento atuarial per capita dos 605 planos de benefícios entre os anos de 2008 e 2014:

Bal. per cap. $_{\text {it }}=\beta_{0}+\beta_{1} C V_{i}+\beta_{2} C_{i}+\beta_{3}$ Patr $_{\cdot i}+\beta_{4}$ Ind.risco $_{i t}+\beta_{5}$ Ind.mat.pop $_{i t}+\beta_{6}$ Tx. $_{\text {juros }}{ }_{i t}+\alpha_{i}+\varepsilon_{i t}$

Tendo em mente que os efeitos individuais não observados são a adequação e aderência das hipóteses atuariais de cada plano de benefícios às suas massas populacionais, o fator decisivo e mais importante de ser levado em conta para escolha do modelo de painel a ser utilizado é se tais efeitos individuais são ou não correlacionados com os outros regressores da equação.

Conforme já abordado anteriormente, mais especificamente na introdução deste estudo, a modalidade de um plano de benefícios define em grande parte o peso do cálculo atuarial nas suas

\footnotetext{
${ }^{36}$ Mais recentemente alterada pela Resolução CNPC no 15, de 19 de novembro de 2014.
} 
provisões matemáticas, pois planos que garantem benefícios vitalícios e benefícios mínimos, são mais fortemente influenciados pela escolha das hipóteses atuariais e sua aderência do que planos que geram benefícios apenas com acúmulo do saldo de contas. Por consequência, planos na modalidade benefício definido (BD) e contribuição variável (CV), nesta ordem, estão intimamente correlacionados com os efeitos individuais de adequação e aderência das hipóteses atuariais, já os planos na modalidade contribuição definida $(\mathrm{CD})$, por terem menos hipóteses atuariais aplicadas à sua lógica de acumulação de recursos e pagamento de benefícios, são bem menos correlacionados com a aderência de tais hipóteses. Analisando os regressores patrocínio predominante dos planos, indicador de perfil de risco e indicador de maturidade populacional, não há como afirmar ex-ante se há ou não correlação com a aderência das hipóteses atuariais, pois o fato de um plano ter patrocínio predominante de empresa pública ou privada não garante uma maior ou menor aderência de hipóteses, tampouco um perfil de investimento mais ou menos arriscado, assim como o nível de maturidade de um plano. Já no que concerne à taxa real anual de juros, por ser uma hipótese atuarial, a sua escolha estará diretamente correlacionada com a sua aderência e adequação aos fluxos projetados e à massa do plano, não necessariamente haverá uma relação de causalidade entre uma mudança na taxa e a aderência de tal taxa à massa de participantes e assistidos de um plano, mas definitivamente há correlação entre o efeito individual de aderência e adequação e qualquer hipótese atuarial.

Portanto, a hipótese do modelo de efeitos aleatórios da não correlação entre os regressores e a heterogeneidade individual não observada não é obedecida para a equação do balanceamento atuarial per capita proposta, conforme confirmado pelo teste do multiplicador de Lagrange de Breusch-Pagan. O teste do multiplicador de Lagrange de Breusch-Pagan examina se os componentes individuais da variância (entre indivíduos ou temporal) são iguais a zero. Se a hipótese nula é rejeitada, pode-se concluir que há efeito aleatório significante nos dados analisados e que o modelo de efeito aleatório é capaz de lidar com a heterogeneidade dos indivíduos melhor que o modelo de mínimos quadrados ordinários. Como a estatística do Multiplicador de Lagrange tem uma distribuição $\chi^{2}$ com 1 grau de liberdade, verificou-se a não rejeição da hipótese nula, visto que o valor calculado de $\chi^{2}(1)$ foi 0,01 , o que corresponde a uma probabilidade menor do que $\chi^{2}$ de $90,75 \%$, portanto, como já aventado, não há indícios de que os efeitos individuais não sejam correlacionados com os regressores, conforme demonstrado na tabela abaixo: 
Tabela 2 - Teste do multiplicador de Lagrange Breusch-Pagan para efeitos aleatórios

Teste do multiplicador de Lagrange de Breusch-Pagan para efeitos aleatórios

\begin{tabular}{|c|c|c|c|}
\hline \multirow[t]{4}{*}{ Resultados estimados: } & & Variância & Desvio padrão \\
\hline & Balanceamento per capita & $2,41 E+16$ & $1,55 E+08$ \\
\hline & $\mathrm{e}$ & $2,42 E+16$ & $1,55 E+08$ \\
\hline & $\mathrm{u}$ & $2,52 E+12$ & 1587629 \\
\hline \multicolumn{4}{|l|}{ Teste $\operatorname{Var}(\mathrm{u})=0$} \\
\hline & & $\chi^{2}(1)=$ & 0,01 \\
\hline & & Probabilidade $>\chi^{2}=$ & 0,9075 \\
\hline
\end{tabular}

Fonte: Elaboração da autora a partir dos resultados obtidos pelo software Stata 11.

Já em relação às hipóteses que abarcam a modelagem dos efeitos fixos, lembre-se que é permitido que os regressores sejam correlacionados com o componente individual do termo de erro, pois um modelo de efeito fixo pergunta como a heterogeneidade advinda dos planos de benefícios entre si e/ou do tempo afeta os interceptos, ou seja, o modelo de efeitos fixos captura a heterogeneidade nos interceptos.

Os dois parâmetros de interesse a serem estimados que compõem os interceptos são: $\beta_{0} \mathrm{e}$ $\propto_{i}$. O primeiro $\left(\beta_{0}\right)$ pode ser entendido como parâmetro global ou populacional, já o segundo $\left(\propto_{i}\right)$ varia de plano para plano e captura a heterogeneidade não observada. Com o intuito de testar se existe indício de efeitos fixos para o balanceamento per capita dos planos de benefícios analisados, houve aplicação do teste $\mathrm{F}$, o qual traz como hipótese nula a afirmação de que todos os componentes individuais do erro $\left(\propto_{i}\right)$ são iguais a zero e na hipótese alternativa a afirmação de que pelo menos um dos componentes individuais não é igual a zero. Se há rejeição da hipótese nula, o que significa que pelos menos um intercepto não é zero, pode-se concluir que existe um efeito fixo significante, ou uma melhora significante de ajustamento do modelo. Abaixo segue tabela que mostra o resultado do teste de efeitos fixos descrito:

Tabela 3 - Teste F para efeitos fixos

Teste $\mathrm{F}$ para efeitos fixos

Teste $\mathrm{F}-\mathrm{H}_{0}$ : todos $\propto_{i}=0$

$\mathrm{F}(604,3627)=1,00$

Prob $>F=0,5251$

Fonte: Elaboração da autora a partir dos resultados obtidos pelo software Stata 11. 
Como demonstrado na Tabela 2 acima, não houve rejeição da hipótese nula, visto que a probabilidade de F ser menor que o valor encontrado é de 52,51\%, impossibilitando a rejeição da hipótese nula e a conclusão de que existe um efeito fixo significante para o balanceamento atuarial per capita nos planos de benefícios analisados neste estudo.

Segundo Park (2011), no caso em que não há rejeição da hipótese nula em nenhum dos testes F para efeitos fixos e multiplicador de Lagrange Breusch-Pagan para efeitos aleatórios, há a necessidade de checar se os dados são empilháveis (pooled), por meio de um teste $\mathrm{F}$ específico denominado teste de Chow. O teste de Chow verifica se os parâmetros do modelo (os coeficientes e as inclinações) são estáveis durante o período analisado. A hipótese nula de tal teste é que todos os coeficientes dos regressores são os mesmos, independentemente do ano de observação. Em caso de rejeição da hipótese nula, os dados não são empilháveis (pooled) e apresentam alguma quebra estrutural que deve ser modelada com técnicas de dados de painel e não simplesmente com mínimos quadrados ordinários (MQO). A tabela abaixo apresenta os resultados encontrados para aplicação do teste de Chow para o balanceamento per capita dos planos de benefícios de 2008 a 2014:

Tabela 4 - Teste F de Chow de quebra estrutural/empilhamento de dados

Teste $\mathrm{F}$ de Chow de quebra estrutural/empilhamento de dados

$$
\begin{aligned}
& F=\frac{\left(S Q E_{\text {restrito }}-\left(S Q E_{\text {irrestrito }}\right)\right) / k}{S Q E_{\text {irrestrito }} / T-2 k} \\
& F \sim F_{k, T-2 k} \\
& F=0,11 \\
& \text { Prob }>F=1,00
\end{aligned}
$$

Fonte: Elaboração da autora a partir dos resultados obtidos pelo software Stata 11.

Como o valor calculado $(0,11)$ é menor que o valor tabelado $(1,00)$ da distribuição $F$, não se pode concluir que há quebra estrutural no balanceamento per capita dos planos de benefícios de 2008 a 2014, o que indica uma inexistência de efeitos fixos ou aleatórios que ajudem a explicar as variações observadas entre os planos de benefícios em cada ano ou ao longo dos anos observados. Dessa forma a modelagem de mínimos quadrados ordinários (MQO) aparenta se encaixar no comportamento da variável observada. 


\subsubsection{O perfil de risco dos planos e seus efeitos não observados}

Com o objetivo de ilustrar os efeitos individuais não observados do perfil de risco dos planos de benefícios analisados neste estudo, é mister que se descreva o ambiente de incentivos regulatórios no qual os investimentos dos fundos de pensão brasileiros e, consequentemente, os planos que administram estão inseridos.

A norma em vigor que rege a aplicação e alocação dos recursos dos fundos de pensão brasileiros é a Resolução n 3.792/2009, que foi elaborada pelo Conselho Monetário Nacional e estabelece limites máximos para todos os seis segmentos de aplicação definidos, que são: renda fixa, renda variável, investimentos estruturados, investimentos no exterior, imóveis e operação com participantes. Além dos limites máximos de alocação por segmento de aplicação, a Resolução 3.792 também traz limites máximos de alocação por emissor e limites máximos de concentração por emissor, denotando uma preocupação com a prudência da gestão dos investimentos, a qual deve ser feita dentro dos limites de riscos indispensáveis ao cumprimento dos compromissos atuariais de cada plano de benefícios.

Apesar dos limites máximos prudenciais impostos pela legislação vigente, cada plano de benefícios conta com uma discricionariedade considerável na gestão de seus investimentos, que deve estar refletida na política de investimentos do plano e que define a alocação dos recursos e os limites por segmento de aplicação, meta de rentabilidade, além de outras informações.

A política de investimento de cada plano de benefício é o efeito não observado ou variável latente, e nela está contido o apetite ao risco de cada plano, além de critérios para avaliação de tais riscos, como o risco de crédito, de mercado, de liquidez, operacional, legal e sistêmico. Lembremonos da equação proposta para investigar o indicador de perfil de risco de cada plano de benefícios:

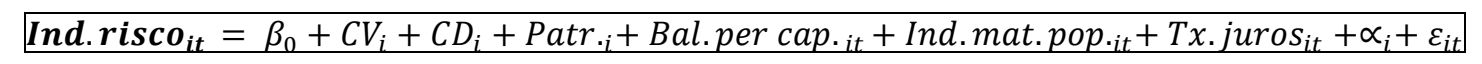

Como a política de investimento de um plano de benefícios objetiva orientar os investimentos segundo as características da massa de participantes e o perfil das obrigações atuariais do plano, é de se esperar que um plano mais maduro, por exemplo, tenha uma política de investimentos que reflita um apetite menor ao risco, portanto supõe-se que a hipótese contida na modelagem de efeitos aleatórios de não correlação dos regressores com a heterogeneidade individual não aparenta ser respeitada. Com o intuito de testarmos a hipótese de não correlação da 
heterogeneidade individual não observada (política de investimentos) com os regressores da equação do indicador de perfil de risco, foi realizado o teste do multiplicador de Lagrange de Breusch-Pagan, conforme a tabela a seguir:

Tabela 5 - Teste do multiplicador de Lagrange Breusch-Pagan para efeitos aleatórios

Teste do multiplicador de Lagrange de Breusch-Pagan para efeitos aleatórios

Indicador de risco $[\mathrm{cnpb}, \mathrm{t}]=\mathrm{Xb}+\mathrm{u}[\mathrm{cnpb}]+\mathrm{e}[\mathrm{cnpb}, \mathrm{t}]$

Resultados estimados:

$\begin{array}{lll} & \text { Variância } & \text { Desvio padrão } \\ \text { Indicador de risco } & 0,0485733 & 0,2203934 \\ \text { e } & 0,0429285 & 0,2071919 \\ \text { u } & 0,0053062 & 0,072844\end{array}$

Teste $\operatorname{Var}(\mathrm{u})=0$

$$
\chi^{2}(1)=150,71
$$

Probabilidade $>\chi^{2}=0,0000$

Fonte: Elaboração da autora a partir dos resultados obtidos pelo software Stata 11.

Percebe-se que houve rejeição da hipótese nula de que os componentes individuais da variância (entre indivíduos ou temporal) são iguais a zero, o que significa que há efeito aleatório significante nos dados analisados para o indicador de perfil de risco e que o modelo de efeitos aleatórios lida com a heterogeneidade individual verificada na política de investimentos de cada plano de benefícios melhor que o modelo de mínimos quadrados ordinários.

Buscando ajustar os dados à modelagem que melhor lida com a heterogeneidade individual não observada e sabendo que os efeitos aleatórios lidam melhor com tal heterogeneidade do que mínimos quadrados ordinários, resta ainda testar se há indício de efeitos fixos no indicador de perfil de risco dos planos de benefícios analisado. Houve aplicação do teste F, o qual traz como hipótese nula a afirmação de que todos os componentes individuais do erro $\left(\propto_{i}\right)$ são iguais a zero e na hipótese alternativa a afirmação de que pelo menos um dos componentes individuais não é igual a zero. Se há rejeição da hipótese nula, então pelos menos um intercepto não é zero e conclui-se que existe efeito fixo significante. Abaixo segue a aplicação do teste F para o indicador perfil de risco dos planos: 
Tabela 6 - Teste F para efeitos fixos

Teste $\mathrm{F}$ para efeitos fixos

Teste $\mathrm{F}-\mathrm{H}_{0}$ : todos $\propto_{i}=0$

$F(604,3)=1,87$

Prob $>F=0,0000$

Fonte: Elaboração da autora a partir dos resultados obtidos pelo software Stata 11.

Como observado na tabela 5, houve rejeição da hipótese nula de que pelo menos um dos interceptos não é zero e pode-se concluir que há indícios de efeitos fixos na heterogeneidade não observada para o indicador de perfil de risco. No caso em que há rejeição das hipóteses nulas dos testes tanto para efeitos aleatórios quanto para efeitos fixos, é necessária a realização de um terceiro teste denominado teste de Hausman, o qual compara os dois modelos sob a hipótese nula de que os efeitos individuais não são correlacionados com qualquer regressor do modelo. Portanto, no caso de haver rejeição da hipótese nula, considera-se o modelo de efeitos fixos melhor ajustável aos dados e caso não haja rejeição da hipótese nula, o modelo de efeitos aleatórios se mostra mais adequado na descrição dos dados. Abaixo, segue o resultado do teste realizado:

Tabela 7 - Teste de Hausman

Teste de Hausman

Teste $\mathrm{F}-\mathrm{H}_{0}$ : diferença nos coeficientes não é sistemática

chi2 $(2)=(b-B)^{\prime}\left[\left(V_{-} b-V_{-} B\right)^{\wedge}(-1)\right](b-B)$

$\operatorname{chi} 2(2)=-5,73$

$\chi^{2}<0,00$

Fonte: Elaboração da autora a partir dos resultados obtidos pelo software Stata 11.

O resultado do teste apontou que o valor encontrado gerou a possibilidade de rejeição da hipótese nula, o que é a mesma coisa que afirmar que as estimativas com o modelo de efeitos fixos e o modelo de efeitos aleatórios divergem significativamente e que o modelo de efeitos fixos se ajusta melhor à equação para o indicador de perfil de risco dos planos de benefícios analisados de 2008 a 2014. Portanto, o modelo de efeitos fixos será aquele a ser estimado, pelas razões aqui expostas. 


\section{RESULTADOS ENCONTRADOS E DISCUSSÕES}

Neste capítulo do trabalho, analisaremos os resultados encontrados a partir das equações estimadas descritas no capítulo anterior, acompanhados dos questionamentos e discussões pertinentes a cada variável averiguada.

\subsection{O balanceamento per capita}

Conforme explicitado no Capítulo 4, seção 4.3.1, as variáveis inseridas na equação estimada para o balanceamento atuarial per capita não se ajustaram à modelagem proposta para os efeitos não observados fixos ou aleatórios, e por isso os resultados comentados a seguir se referem a uma regressão linear múltipla com dados empilhados, estimados por mínimos quadrados ordinários (pooled OLS).

Primeiramente cabe relembrar da equação estimada para o balanceamento atuarial per capita:

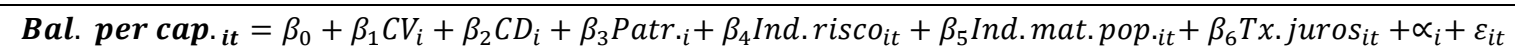

Segue a tabela com os resultados da equação estimada:

Tabela 8: Regressão linear múltipla com dados empilhados

\begin{tabular}{|l|c|}
\hline & $\begin{array}{l}\text { Variável dependente: Balanceamento } \\
\text { atuarial per capita (desvio padrão entre } \\
\text { parênteses) }\end{array}$ \\
\hline Contribuição variável & $-8.918 .400^{* *}$ \\
\hline Contribuição definida & {$[5.513 .073]^{*}$} \\
\hline & -9.958 .733 \\
Patrocínio privado & {$[6.667 .790]^{*}$} \\
\hline & -1.891 .853 \\
Taxa real anual de & {$[6.180 .023]^{*}$} \\
juros & -1.784 .798 \\
\hline \multicolumn{1}{l}{$\begin{array}{l}\text { Indicador de perfil de } \\
\text { risco }\end{array}$} & {$[2.299 .989]^{*}$} \\
\hline $\begin{array}{l}\text { Indicador de } \\
\text { maturidade } \\
\text { populacional }\end{array}$ & -10.500 .000 \\
\cline { 1 - 2 } & {$[10.900 .000]^{*}$} \\
\hline
\end{tabular}




\begin{tabular}{|l|r|}
\hline & {$[95.612,22]^{*}$} \\
\hline Constante & $24.000 .000^{* *}$ \\
\hline $\mathrm{R}^{2}$ & {$[14.100 .000]$} \\
\hline $\mathrm{R}^{2}$ ajustado & 0,0013 \\
\hline
\end{tabular}

*Desvio-padrão

**Coeficientes significantes a $10 \%$

Fonte: Elaboração da autora a partir dos resultados obtidos pelo software Stata 11.

Aponte-se que apenas os coeficientes relativos à constante e à variável dummy modalidade CV foram estatisticamente significantes ao nível de 10\%. De toda forma, a significância estatística do intercepto e do coeficiente relativo à modalidade de plano CV são consistentes com o que se esperava, pois apenas os planos que tem benefícios com cálculo atuarial, devem apresentar balanceamento maior ou menor que zero; só há de se falar em resultado atuarial em planos que possuem algum benefício definido. Como o intercepto representa o balanceamento atuarial per capita dos planos de benefícios na modalidade benefício definido com patrocínio público, a expectativa é que ele fosse estatisticamente significante e positivo. De fato, verifica-se que o balanceamento atuarial per capita ao longo dos anos observados está positivo em um valor de R\$ 24 milhões. Isso significa que os participantes dos planos BD com patrocínio público, em média, tiveram suas provisões matemáticas cobertas e ainda possuíram um superávit per capita de valor expressivo no período de 2008 a 2014. No entanto cabe ressaltar que os planos maiores e com boa performance tendem a enviesar e elevar o valor médio do balanceamento per capita. Já em relação aos planos na modalidade CV também com patrocínio público, verificou-se que um balanceamento atuarial per capita médio no período de análise foi em torno de $\mathrm{R} \$ 15$ milhões, valor alto se for levado em consideração que o peso do cálculo atuarial envolvido em tais planos é menor que nos planos BD, pois nem todos os benefícios são pagos vitaliciamente.

Como não houve possibilidade de rejeição da hipótese nula de que os outros coeficientes estimados para as demais variáveis explicativas da equação são diferentes de zero, discutiremos somente os sinais desses coeficientes.

Para o coeficiente que descreve os planos CD era esperado que, a depender do sinal da constante, o efeito dessa modalidade de plano fosse na direção do balanceamento, aproximando-o de um resultado zero, pois como explicamos no Capítulo 2, Seção 2.2, os planos na modalidade $\mathrm{CD}$, por serem planos em que o benefício não é definido, mas sim a contribuição, tendem a ter suas obrigações iguais às suas contribuições e rendimentos auferidos. Mesmo que o coeficiente 
calculado não tenha sido significante ao nível de 10\%, o efeito observado foi coerente com a expectativa e em valores maiores (valores absolutos) do que os observados para os planos de modalidade $\mathrm{CV}$.

Em relação ao patrocínio predominante, de acordo com o que fora exposto no Capítulo 4, Seção 4.2, Gráficos 12 e 13, os planos com patrocínio privado apresentam um melhor balanceamento. O efeito observado foi negativo e, dado que a constante é positiva, ele funcionaria como um redutor do balanceamento positivo, o que acarretaria em um melhor balanceamento dos planos de benefícios com patrocínio privado. Umas das possíveis razões para tal fato pode ser um menor custo administrativo por parte das EFPC que administram planos com patrocínio privado, como apontou Caetano (2013) em seu estudo empírico sobre economias de escala e escopo na previdência complementar fechada brasileira. Como resultado da equação estimada para as despesas administrativas das EFPC, Caetano conclui que aquelas com patrocínio privado apresentaram despesas administrativas $12 \%$ inferiores às públicas no biênio 2010 a $2011^{37}$, o que pode ser decorrente da maior eficiência das EFPC que administram planos com patrocínio privado, ou da menor rigidez legal que se aplica a tais planos em comparação com os de patrocínio público.

O coeficiente relativo à taxa real anual de juros, apesar de também não ser significante ao nível de $10 \%$, apresentou sinal diferente do esperado. Sabe-se que se há aumento da taxa real anual de juros usada como taxa de desconto, as provisões matemáticas trazidas a valor presente tornamse menores e, como o patrimônio de cobertura do plano não se altera com a mudança do valor da taxa, o esperado é que o balanceamento seja mais positivo. Entretanto o sinal encontrado na equação estimada do coeficiente foi negativo e não conseguimos identificar sua causa. A conjuntura econômica do período amostral foi caracterizada por forte queda na taxa SELIC e as taxas observadas para os planos de benefícios parecem ter acompanhado esse movimento. Dentro do período analisado houve também forte valorização de ativos como imóveis e títulos públicos prefixados e indexados à inflação, dessa forma, poderia haver uma correlação espúria: houve um processo de longo prazo (pelo menos até 2013) de queda na taxa SELIC, acompanhado de valorização de ativos. Ao mesmo tempo, houve redução na taxa de juros, o que eleva o valor presente das provisões matemáticas. Entretanto, o primeiro efeito teria predominado. Em situações

\footnotetext{
${ }^{37}$ O estudo levou em consideração 265 EFPC.
} 
"normais", não teria havido nenhuma tendência definida na taxa SELIC, não afetando o patrimônio de cobertura.

Já para o indicador de perfil de risco, o efeito verificado foi negativo, apontando para um eventual balanceamento per capita negativo, no caso de planos com perfil de risco mais agressivo.

Finalmente, no que concerne ao coeficiente estimado para o indicador de maturidade populacional foi verificado um efeito negativo e de pouca intensidade se comparado às outras variáveis, aproximando os planos da situação de balanceamento. Em condições normais, os planos mais maduros, que já estão na fase de dispêndio de recursos acumulados na forma de pagamento de benefícios, devem ter acumulado recursos suficientes para fazer frente às suas obrigações.

A próxima seção analisará o indicador de perfil de risco.

\section{$5.2 \mathrm{O}$ indicador de perfil de risco}

Alinhado ao modelo proposto por Andonov et al (2014) e descrito no Capítulo 3, Seção 3.2, segue a equação estimada para o indicador de perfil de risco:

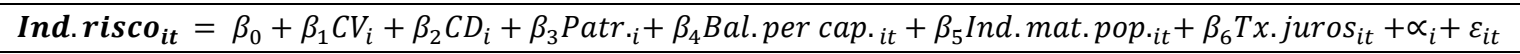

Conforme explicitado no Capítulo 4, Seção 4.3.2 o indicador de perfil de risco apresentou características que se ajustaram à modelagem de efeitos fixos e os resultados encontrados para a equação estimada foram:

Tabela 9: Regressão com efeitos fixos (Within)

\begin{tabular}{|l|c|}
\hline & $\begin{array}{l}\text { Variável dependente: Indicador de perfil } \\
\text { de risco (desvio padrão entre parênteses) }\end{array}$ \\
\hline $\begin{array}{l}\text { Taxa real anual de } \\
\text { juros }\end{array}$ & 0,0093 \\
\hline & {$[0,0044]^{*}$} \\
$\begin{array}{l}\text { Balanceamento } \\
\text { atuarial per capita }\end{array}$ & $-4,96 \mathrm{E}-12$ \\
\hline $\begin{array}{l}\text { Indicador de } \\
\text { maturidade } \\
\text { populacional }\end{array}$ & {$[2,21 \mathrm{E}-11]^{*}$} \\
\hline
\end{tabular}




\begin{tabular}{|c|c|}
\hline & {$[0,00013]^{*}$} \\
\hline & $0,3064 * *$ \\
\hline Constante & {$[0,0234]^{*}$} \\
\hline $\mathrm{R}^{2}$ within & 0,0012 \\
\hline$R^{2}$ between & 0,0038 \\
\hline $\mathrm{R}^{2}$ overall & 0,0000 \\
\hline
\end{tabular}

*Desvio-padrão

**Coeficientes significantes a $10 \%$

Fonte: Elaboração da autora a partir dos resultados obtidos pelo software Stata 11.

A equação do indicador de perfil de risco apenas apresentou coeficientes estatisticamente significantes ao nível de $10 \%$ para a constante e para a taxa real anual de juros. Todas as variáveis dummies inseridas no modelo (modalidades CD e CV e patrocínio) não foram estimadas por não variarem ao longo dos $\operatorname{anos}^{38}$, conforme já era esperado para um modelo de efeitos fixos, portanto as interpretações aqui realizadas se referem aos planos BD com patrocínio público.

Verificou-se que os planos BD entre os anos de 2008 e 2014 apresentaram, em média, um indicador de perfil de risco de 30,64\%, considerando-se os valores médios das variáveis independentes. Em uma primeira análise pode-se perceber que a conclusão de que planos mais maduros investem menos em ativos arriscados, conforme prevê a teoria do capital humano do ciclo de vida aqui exposta, não foi confirmada pela análise de painel. Adicionalmente, se compararmos a evolução do indicador de maturidade dos planos BD na forma descrita no Capítulo 4, Gráfico 16 e as evoluções do mesmo indicador dos planos CV e CD (Gráficos 17 e 18) com a diferença encontrada entre os indicadores de perfil de investimento na equação estimada, não se verifica que a diferença encontrada corrobore com a teoria.

O coeficiente estimado para o indicador de maturidade populacional não foi estatisticamente significante diferente de zero e apresentou sinal oposto ao esperado pela teoria do ciclo de vida.

Em relação ao coeficiente estimado para a taxa real anual de juros, foi o único além da constante estatisticamente significante ao nível de 10\%, cabe apontar que seu efeito positivo verificado parece estar em linha com o que dita a regra de precificação de passivo constante da Resolução CNPC no 18/2006. O dispositivo legal versa que a taxa real anual usada como taxa de

\footnotetext{
${ }^{38}$ As variáveis foram omitidas da regressão por apresentarem colinearidade.
} 
desconto do passivo atuarial dos planos de benefícios deve corresponder ao valor esperado da rentabilidade futura dos investimentos e, sabendo que a expectativa de retorno de longo prazo sobre ativos como ações e títulos privados tende a ser maior do que aquela verifica em títulos públicos, é factível que haja uma relação positiva entre o perfil de risco e a taxa de desconto. Planos com perfil de risco mais agressivo, incrementaria sua taxa de desconto do passivo, com expectativa de maiores retornos sobre os investimentos no futuro. Contudo, conforme apontou o estudo empírico realizado por Andonov et al (2014) nos fundos de pensão públicos estadunidenses, é importante que seja estudado se essa relação positiva de fato se reverte em performance de rentabilidade dos ativos.

Finalmente, em relação ao balanceamento atuarial per capita, o coeficiente estimado também não foi significante ao nível de $10 \%$ e foi o único com sinal negativo. Uma possível interpretação para esse efeito negativo seria que planos mais balanceados tendem a investir menos em ativos de risco, o que não tem respaldo teórico ${ }^{39}$.

\footnotetext{
${ }^{39}$ Seria possível verificar se tal relação existe se a performance dos investimentos fosse averiguada. O estudo aqui proposto não levou em consideração a performance dos ativos dos planos de benefícios.
} 


\section{CONSIDERAÇÕES FINAIS}

Podemos concluir pelas dados e resultados demonstrados nesse estudo que não foi confirmada a correlação esperada entre a maturidade dos planos de benefícios e o perfil de risco, conforme a teoria do ciclo de vida do capital humano prevê. Teceremos alguns comentários em relação às possíveis explicações para o comportamento verificado.

A falta de correlação encontrada para os 605 planos de benefícios neste estudo entre a maturidade do plano e a quantidade de ativos de risco investidos, poderia indicar que a política de investimentos dos planos de benefícios não está levando em consideração a vontade dos participantes e assistidos desses planos, parte interessada diretamente afetada pelos resultados. Supondo que a teoria do ciclo de vida do capital humano capta a vontade dos indivíduos, refletindo o que a população deseja, no caso específico o que os participantes de um plano de benefícios desejam, podemos entender que as EFPC não parecem estar tomando as decisões com relação à política de investimentos da forma que seus participantes prefeririam. Tal fato pode ser derivado da falta de mecanismos de incentivo que possibilitem que as preferências dos indivíduos sejam capturadas, principalmente em relação às decisões de investimento.

Como o vínculo do participante com um plano de benefícios é rígido, pois uma vez parte de um plano, o participante somente pode deixá-lo se não mais tiver relação de trabalho com o empregador $^{40}$, suas escolhas tornam-se restringidas pela falta de concorrência. Se um participante está insatisfeito com o perfil de investimento que seu plano de benefícios tem, ele não pode se direcionar a outro plano, pois essa mobilidade não existe nas regras vigentes para o sistema de previdência complementar fechado. Essa rigidez verificada no mercado das EFPC brasileiras restringe sobremaneira o reflexo das escolhas dos indivíduos em relação ao perfil de investimento, pelo fato de não ser verificada concorrência entre os planos de benefícios da previdência complementar fechada.

Não há na legislação das EFPC hoje em vigência qualquer incentivo ou vinculação regulatória que defina padrões de investimento baseados na teoria do ciclo de vida, conforme já

\footnotetext{
${ }^{40}$ Ver Resolução MPS/CGPC № 06, de 30 de outubro de 2003, que trata dos institutos da portabilidade e resgate.
} 
implementado em outros países como EUA e Austrália, principalmente para os planos de modalidade CD. A regulação verificada nesses países prescreve opções de investimento padrões de acordo com os preceitos da teoria do ciclo de vida do capital humano. Tais opções são obrigatórias para os participantes de planos de benefício que não tenham escolhido um portfólio específico de acordo com seu perfil de risco.

Uma regulação que exigisse escolhas de investimentos baseadas na teoria do ciclo de vida, ou que impedisse que planos de benefícios muito maduros investissem fortemente em ativos com maior risco permitiria a existência de incorporação das preferências dos indivíduos de forma que houvesse uma convergência no comportamento do perfil de risco do plano e dos participantes pertencentes a esses planos.

Conforme descrito neste estudo, o futuro da previdência complementar brasileira está nas modalidades CV e CD e é exatamente em tais planos que os incentivos regulatórios deveriam mirar, objetivando capturar as preferências dos participantes nas decisões de investimento dos planos de benefícios. 


\section{REFERÊNCIAS BIBLIOGRÁFICAS}

ANDONOV, Aleksandar and BAUER, Rob and CREMERS, Martijn. Pension Fund Asset Allocation and Liability Discount Rates (May 2014).

BATALGI, Badi H. Econometric Analysis of Panel Data. $3^{\text {rd }}$ edition - John Wiley \& Sons, Ltd, . 2005.

BENJAMIN, Bernard. General Insurance. London: Heinemann, 1977.

BIKKER, Jacob; BROEDERS, Dirk; HOLLANDERS David; e PONDS, Eduard: "Pension funds asset allocation and participant age: a test of the life-cycle model". DNB Working Paper, 2009.

BODIE, Zvi, Life-Cycle Finance in Theory and in Practice (April 2002). Boston University School of Management Working Paper No. 2002-02.

BRASIL. Casa Civil. Lei no 8.213, de 24 de julho de 1991.

BRASIL. Ministério da Previdência Social. Resolução CGPC nº 18, de 28 de março de 2006. Brasília, DF, 2006.

BRASIL. Ministério da Previdência Social. Resolução CGPC nº 26, de 29 de setembro de 2008. Brasília, DF, 2008.

BRASIL. Ministério da Previdência Social. Resolução CGPC nº 12, de 17 de setembro de 2002 Brasília, DF, 2002.

BRASIL. Ministério da Previdência Social. Resolução CGPC No 14, de $1^{\circ}$ de outubro de 2004. Brasília, DF, 2004.

BRASIL. Ministério da Previdência Social. Resolução CGPC No 16, de 22 de novembro de 2005. Brasília, DF, 2005.

BRASIL. Ministério da Previdência Social. Resolução CNPC No 08, de 31 de outubro de 2011. Brasília, DF, 2011.

BRASIL. Ministério da Previdência Social. Resolução CNPC No 06, de 30 de outubro de 2003. Brasília, DF, 2003.

BRASIL. Ministério Fazenda. Resolução CMN No 3.792, de 24 de setembro de 2009 Brasília, DF, 2009.

BRASIL. Lei Complementar no 109, de 29 de maio de 2001. Brasília, DF, 2001.

BRASIL. Lei Complementar nº 108, de 29 de maio de 2001. Brasília, DF, 2001 
BRASIL. Superintendência Nacional de Previdência Complementar. Instrução Previc nº 12, de 13 de outubro de 2014. Brasília, DF, 2014.

BRASIL. Superintendência Nacional de Previdência Complementar. Instrução Previc no 19, de 04 de fevereiro de 2015. Brasília, DF, 2015.

BRASIL. Superintendência Nacional de Previdência Complementar. Instrução Previc nº 07, de 12 de dezembro de 2013. Brasília, DF, 2013.

BRASIL. Superintendência Nacional de Previdência Complementar. Instrução Previc n⿳0 20, de 20 de março de 2015. Brasília, DF, 2015.

BRASIL. Superintendência Nacional de Previdência Complementar. Instrução Previc no 21, de 23 de março de 2015. Brasília, DF, 2015.

BRASIL. Superintendência Nacional de Previdência Complementar. Instrução SPC no 24, de 05 de junho de 2008. Brasília, DF, 2008.

BRASIL. Superintendência Nacional de Previdência Complementar. Instrução SPC nº 34, de 24 de setembro de 2009. Brasília, DF, 2008.

BRASIL. Superintendência Nacional de Previdência Complementar. Guia Previc - Melhores Práticas Atuariais para Entidades Fechadas de Previdência Complementar, 2012.

BRUNI, A. L. (1998). Risco, Retorno e Equilíbrio : Uma Análise do Modelo de Precificação de Ativos Financeiros na Avaliação de Ações Negociadas na Bovespa (1988- 1996). Dissertação de Mestrado apresentada à Faculdade de Economia, Administração e Contabilidade da Universidade de São Paulo.

CAETANO, Marcelo Abi-Ramia. Economias de escala e escopo na previdência complementar fechada brasileira. Texto de Discussoão IPEA, 2014.

DEATON, Angus. "Franco Modigliani and the life-cycle theory of consumption”, 2005.

FAMÁ, R.; KAYO, E. K. e M., SOUZA, M. A. S: “Teorias de consumo/poupança e o sistema previdenciário brasileiro". Caderno de pesquisas em administração, São Paulo, V.1., n 6, $1^{\circ}$ trimestre 1998.

FERREIRA, Paulo Pereira; MANO, Cristina Cantanhede Amarante. Aspectos Atuariais e Contábeis das Provisões Técnicas. Rio de Janeiro: Funenseg, 2009.

GAZZONI, Antônio F. Precificação de Ativos e Passivos e solvência de planos de benefícios. $35^{\circ}$ Congresso dos Fundos de Pensão Brasileiros, 2014.

GRENE, William H. Econometric Analysis. 5th edition - New York University, 2003. 
INKMANN, J.; SHI, Z. Life Cycle Patterns In The Design And Adoption of Default Funds in DC pension plans, 2014.

KENNEDY, Peter. A Guide to Econometrics, 6th ed. Malden, MA: Blackwell Publishing, 2008.

MERTON, Robert C. Continuous-Time Finance. Oxford, U.K.: Basil Blackwell, 1990.

NUNES, L. E. Decisão de Investimento: Uma proposta de adequação da Teoria Moderna de Portfólio e Life Cycle Investing na Previdência Complementar brasileira. Dissertação (mestrado) Universidade Federal de Santa Catarina, Centro Socioeconômico. Programa de PósGraduação em Administração, 2013.

PARK, Hun Myoung. Practical Guides to Panel Data Modelling: A step by step analysis using Stata, 2011.

PINHEIRO, R. P. A demografia dos fundos de pensão. Coleção Previdência Social, Série Estudos, v. 24. Brasília, DF: Ministério da Previdência Social, Secretaria de Políticas de Previdência Social, 2007.

PINHEIRO, R. P.; PAIXÃO, L.A.; CHEDEAK, J.S. Regulação dos investimentos nos fundos de pensão: evolução histórica, tendências recentes e desafios regulatórios. Revista de Previdência, n. ${ }^{\circ}$ 3. Rio de Janeiro: Faculdade de Direito / UERJ, outubro de 2005.

RANGEL, L. A. A criação da previdência complementar dos servidores públicos e a instituição de um teto para os valores dos benefícios: Implicações na distribuição de renda e na taxa de reposição das aposentadorias.2013. 234 f. Tese (Doutorado em Políticas Públicas, Estratégias e Desenvolvimento) - UFRJ, Rio de Janeiro, 2013.

SILVA, R. S. Fortalecer a Governança é a Chave para Evitar Problemas nos Fundos de Pensão. Núcleo de Estudos e Pesquisas/CONLEG/Senado, abril de 2015 (Boletim do Legislativo ${ }^{\circ} 28$ de 2015). Disponível em: www.senado.gov.br/estudos

VICEIRA, Luis M. "Pension Fund Design in Developing Economies." In Evaluating the Financial Performance of Pension Funds, edited by Richard Hinz, Heinz P. Rudolph, Pablo Antolin, and Juan Yermo. World Bank, 2010.

WOOLDRIDGE, Jefrey M. Econometris Analysis of Cross Section and Panel Data. $2^{\text {nd }}$ edition, 2010. 